\title{
Spinnen in Agrarlandschaften und die biologische Kontrolle von Getreideblattläusen
}

\author{
Dissertation \\ zur Erlangung des Doktorgrades \\ an der Fakultät für Agrarwissenschaften \\ der Georg-August-Universität Göttingen
}

vorgelegt von

Martin H. Schmidt

geboren in Erlangen

Göttingen, Mai 2004 
D7

1. Referent: Prof. Dr. Teja Tscharntke

2. Korreferent: Prof. Dr. Stefan Vidal

Tag der mündlichen Prüfung: 27.05.2004 


\section{Inhaltsverzeichnis}

1 Überblick

Einleitung 4

Untersuchungsgebiet und Organismen $\quad 5$

$\begin{array}{ll}\text { Fragestellung } & 7\end{array}$

Ergebnisse und Schlussfolgerungen $\quad 8$

2 The role of perennial habitats for Central European farmland spiders 11

Introduction $\quad 11$

Materials and methods $\quad 13$

$\begin{array}{lr}\text { Results } & 14\end{array}$

$\begin{array}{lr}\text { Discussion } & 18\end{array}$

3 Landscape context affects the diversity, and local management the density of $\begin{array}{ll}\text { farmland spiders } & 21\end{array}$

$\begin{array}{ll}\text { Introduction } & 21\end{array}$

Materials and methods $\quad 23$

Results 24

Discussion $\quad 26$

4 Landscape context of sheetweb spider population dynamics in cereal fields $\quad 30$

$\begin{array}{ll}\text { Introduction } & 31\end{array}$

Materials and methods $\quad 33$

Results $\quad 34$

$\begin{array}{ll}\text { Discussion } & 37\end{array}$

5 Relative importance of predators and parasitoids for cereal aphid control $\quad 40$

Introduction $\quad 40$

Materials and methods $\quad 41$

Results 43

Discussion 46

6 Aphid suppression by natural enemies in mulched cereals 49

Introduction $\quad 49$

Materials and methods $\quad 51$

Results $\quad 52$

Discussion $\quad 55$

7 The landscape context of arthropod biological control 58

Introduction $\quad 58$

$\begin{array}{ll}\text { Two case studies: cereals and oilseed rape } & 59\end{array}$

$\begin{array}{ll}\text { Enhanced biological control in complex landscapes } & 60\end{array}$

$\begin{array}{ll}\text { Functional scales of landscape processes } & 61\end{array}$

$\begin{array}{ll}\text { Temporal dynamics } & 63\end{array}$

Interactions between local and regional diversification $\quad 64$

$\begin{array}{ll}\text { Counteracting processes } & 65\end{array}$

$\begin{array}{ll}\text { Conclusions } & 65\end{array}$

$\begin{array}{ll}\text { Literaturverzeichnis } & 67\end{array}$

$\begin{array}{ll}\text { Summary } & 76\end{array}$

$\begin{array}{ll}\text { Zusammenfassung } & 77\end{array}$

$\begin{array}{lr}\text { Danksagung } & 79\end{array}$

$\begin{array}{lr}\text { Publikationen } & 80\end{array}$

$\begin{array}{ll}\text { Lebenslauf } & 81\end{array}$ 


\section{Spinnen in Agrarlandschaften und die biologische Kontrolle von Getreideblattläusen. Ein Überblick}

\section{Einleitung}

Intensivierung und Ausweitung des Ackerbaus während der letzten Jahrzehnte und die damit verbundene Abnahme naturnaher Lebensräume verursachten den Rückgang zahlreicher Arten, insbesondere Vögel und Pflanzen (Krebs et al. 1999, Benton et al. 2003). Die Bestandsentwicklung wirbelloser Tiere in der Agrarlandschaft ist weniger gut dokumentiert, es gibt jedoch Hinweise, dass auch Insekten- und Spinnenarten zurückgegangen sind (Heydemann \& Meyer 1983, Aebischer 1991). Neben dem Wert der Artenvielfalt an sich könnten damit auch wichtige ökologische Funktionen verloren gehen, wie die natürliche Schädlingskontrolle (Kruess \& Tscharntke 1994, Sunderland et al. 1997, Holt et al. 1999, Thies \& Tscharntke 1999, Gurr et al. 2003, Tscharntke et al. 2003).

Zur Förderung der Artenvielfalt im Ackerland wurden in der Vergangenheit vor allem lokale Maßnahmen untersucht. Dazu zählt beispielsweise der eingeschränkte Gebrauch von Pestiziden, blütenreiche Untersaaten, organischer Mulch oder schonende Bodenbearbeitung (Altieri et al. 1993, Landis et al. 2000, Sunderland \& Samu 2000, Lee et al. 2001, Kean et al. 2003). Da Arthropoden oft sehr mobil sind und viele Arten nur einen Teil ihres Lebenszyklus auf Äckern vollenden, hat die Zusammensetzung der Landschaft einen großen Einfluss auf die Populationsgrößen und muss für eine gezielte Förderung berücksichtigt werden (Ricklefs 1987, Kareiva 1990, Tscharntke \& Brandl 2004). So zeigen aktuelle Arbeiten, dass die Parasitierung schädlicher Insekten durch Schlupfwespen und Raupenfliegen in hohem Maße von der umgebenden Landschaft bestimmt wird (Roland \& Taylor 1997, Thies \& Tscharntke 1999, Thies et al. 2003). Die Blütenbestäubung durch Wildbienen hängt ebenfalls vom Anteil naturnaher Lebensräume in der Landschaft ab (Steffan-Dewenter et al. 2002). Spinnen gehören durch ihren Artenreichtum und ihre hohen Abundanzen $\mathrm{zu}$ den bedeutendsten Prädatoren und Bioindikatoren in der Agrarlandschaft (Ekschmitt et al. 1997, Marc et al. 1999, Symondson et al. 2002, Cole et al. 2003). Für sie wurden ebenfalls Einflüsse der Landschaftszusammensetzung vermutet und modelliert, jedoch erst wenig im Freiland überprüft (Topping \& Sunderland 1994, Halley et al. 1996, Topping 1997, 1999, Sunderland \& Samu 2000). 
Die vorliegende Arbeit untersucht das Vorkommen von Spinnen in der Agrarlandschaft in Abhängigkeit von der Landschaftszusammensetzung. Die Landschaftseffekte werden mit der Wirkung lokaler Faktoren wie Mulch und ökologischer Bewirtschaftung verglichen. In Freilandexperimenten zur natürlichen Kontrolle von Getreideblattläusen wird die Bedeutung von Spinnen und andere Gegenspielern getestet.

\section{Untersuchungsgebiet und Organismen}

Das Hauptuntersuchungsgebiet, der Landkreis Göttingen, liegt im südniedersächsischen Bergland mit einem Wechsel von flachwelligen Becken (120-200 m ü. NN) und flachbis steilhängigen Bergzügen (bis $480 \mathrm{~m}$ ü. NN). Er wird zu 52\% (57005 ha) landwirtschaftlich genutzt, gefolgt von 33\% Waldfläche. Von der landwirtschaftlich genutzten Fläche entfallen $85 \%$ auf Äcker und $15 \%$ auf Dauergrünland (Niedersächsisches Landesamt für Statistik 2001). Die wichtigsten Kulturen sind Wintergetreide (v.a. Winterweizen), gefolgt von Winterraps und Zuckerrüben. Innerhalb des Untersuchungsgebietes gibt es Bereiche mit stark kontrastierender Landschaftsstruktur. Ausgeräumte, strukturarme Landschaften bestehen zu mehr als 90\% der Fläche aus Äckern (Abb. 1A). In anderen Landschaften machen Äcker weniger als $40 \%$ der Fläche aus und sind in ein Mosaik aus Grünland, Brachen und Wald eingebettet (Abb. 1B).

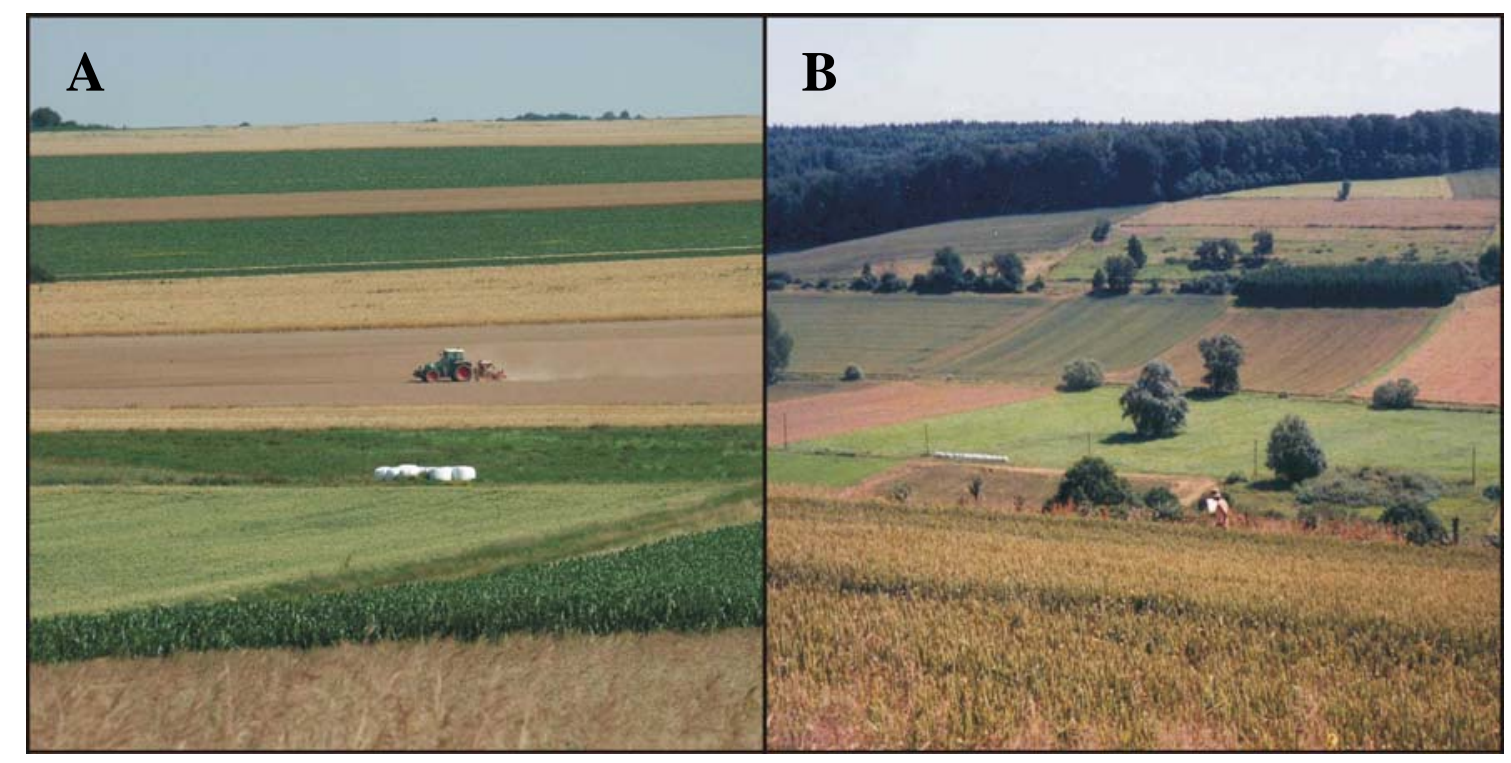

Abbildung 1: A: Ausgeräumte, strukturarme Landschaft bei Ebergötzen, mit 93\% Ackeranteil in einem Kilometer Umkreis (Foto: Katja Poveda). B: Strukturreiche Landschaft bei Landolfshausen mit 38\% Acker und 23\% Grünland (Foto: Indra Roschewitz). 
Die Spinnenfauna von Getreidefeldern wird zahlenmäßig stark von Zwergspinnen (Erigoninae) und Baldachinspinnen (Linyphiinae) dominiert (Samu \& Szinetár 2002, Nyffeler \& Sunderland 2003). Diese bilden gemeinsam die Familie Linyphiidae mit waagrechten Fangnetzen (Decken- bzw. Baldachinnetze) am Boden oder in der Vegetation. Einige Zwergspinnen fangen auch Beute außerhalb ihrer Netze (Heimer \& Nentwig 1991, Roberts 1995). Die meisten Arten sind sehr mobil und unternehmen bei geeignetem Wetter während des ganzen Jahres Ausbreitungsflüge (ballooning, Toft 1995, Thorbek et al. 2002). Besonders zahlreich auf Feldern sind die Zwergspinnen Oedothorax apicatus (Blackwall) und Erigone atra (Blackwall), sowie die Baldachinspinnen Bathyphantes gracilis (Blackwall) und Tenuiphantes tenuis (Blackwall). Daneben treten vor allem Wolfspinnen (Lycosidae) und Kieferspinnen (Tetragnathidae) der Gattung Pachygnatha auf, die wegen ihrer hohen Laufaktivität mit Bodenfallen in großer Zahl gefangen werden. In Grünländern und Brachen haben Wolfspinnen und Kieferspinnen höhere Abundanzen als auf Feldern, und es kommen andere Familien hinzu (u.a. Araneidae, Clubionidae, Thomisidae). Die Überwinterung von Zwerg- und Baldachinspinnen findet wahrscheinlich überwiegend in naturnahen Lebensräumen statt, obwohl sie dort weniger dominant sind als auf Äckern (Łuczak 1979, Dinter 1995, Marc et al. 1999, Lemke \& Poehling 2002, Kapitel 2).

In Mitteleuropa kommen vor allem drei Arten Getreideblattläuse (Aphididae) vor. Dies sind Sitobion avenae (Fabricius), Metopolophium dirhodum (Walker) und Rhopalosiphum padi (Linnaeus), die das Getreide in manchen Jahren schädigen können, und gegen die häufig Insektizide eingesetzt werden. Getreideblattläuse bilden neben Springschwänzen (Collembola) und Zweiflüglern (Diptera) die Hauptnahrung von Spinnen auf Feldern (Nyffeler 1999). Darüber hinaus gehören Marienkäfer (Coccinellidae), Schwebfliegen (Syrphidae), Gallmücken (Cecidomyiidae), Florfliegen (Chrysopidae), Schlupfwespen (v.a. Aphidiidae), Laufkäfer (Carabidae) und Kurzflügelkäfer (Staphylinidae) zu ihren natürlichen Gegenspielern (Wratten \& Powell 1991, Sigsgaard 2002, Symondson et al. 2002). 


\section{Fragestellung}

In der vorliegenden Arbeit wurden einerseits Einflüsse von Landschaft und lokalen Faktoren auf Spinnen in Getreidefeldern untersucht, andererseits wurde die Bedeutung von Spinnen und anderen natürlichen Feinden von Getreideblattläusen in zwei Freilandexperimenten getestet. Folgende Fragen standen im Vordergrund:

Wie wirkt sich die Landnutzung als Acker, Grünland oder Brache auf die Spinnengemeinschaften aus? Welche auf Äckern wichtigen Arten kommen auch im Grünland und auf Brachen vor und in welchen Dichten? (Kapitel 2)

Welche relative Bedeutung haben die Zusammensetzung der Landschaft und die Art der Bewirtschaftung für Artenvielfalt und Dichte bodenlebender Spinnen in Weizenfeldern? Sind die Einflüsse der Landschaft auf Spinnen in konventionell bewirtschafteten Feldern größer als in ökologischen? (Kapitel 3)

Hängt der Populationsaufbau von Baldachinspinnen in Weizenfeldern im Frühjahr vom Anteil naturnaher Lebensräume in der umgebenden Landschaft ab? Lassen sich Unterschiede zwischen den Jahren durch das Wetter erklären? (Kapitel 4)

Welchen Einfluss haben bodenlebende und fliegende Gegenspieler auf natürlich vorkommende Blattlaus-Populationen im Winterweizen? Gibt es Interaktionen zwischen den unterschiedlichen Gegenspielergruppen? (Kapitel 5)

Wie beeinflussen bodenlebende und fliegende Gegenspieler experimentell erhöhte Populationen von Rhopalosiphum padi im Sommerweizen? Lassen sich die Dichten bodenlebender Blattlaus-Gegenspieler durch Mulch steigern? Führt dies zu einer erhöhten Blattlaus-Kontrolle? (Kapitel 6)

Kapitel 7 gibt anhand von Fallstudien einen Überblick über die aktuelle Forschung zu den folgenden Fragen: Ist die biologische Kontrolle von Arthropoden in strukturreichen Landschaften erhöht? Auf welchen räumlichen Skalen werden Nützlinge von der Landschaft beeinflusst? Welche Bedeutung hat zeitliche Dynamik innerhalb und zwischen den Jahren? Werden lokale Maßnahmen zur Nützlingsförderung von der umgebenden Landschaft beeinflusst? Welche Prozesse können einer erhöhten biologischen Kontrolle von Arthropoden in strukturreichen Landschaften entgegenwirken? 


\section{Ergebnisse und Schlussfolgerungen}

Im Frühjahr hatten Spinnen in Grünländern und Brachen etwa viermal so hohe Dichten und einen doppelt so hohen Artenreichtum wie im Winterweizen. Insbesondere Erigone atra, Bathyphantes gracilis und Tenuiphantes tenuis hatten in Grünländern und Brachen um ein Mehrfaches höhere Dichten, obwohl sie im Sommer zu den dominanten Arten im Weizen zählen. Lediglich Oedothorax apicatus kam bereits im Frühjahr mit signifikant höheren Dichten auf den Feldern vor als in Grünländern und Brachen. Es ist daher insgesamt zu erwarten, dass das Vorkommen von Spinnen auf Äckern durch naturnahe Lebensräume in der umgebenden Landschaft gesteigert wird. (Kapitel 2)

Hohe Anteile naturnaher Lebensräume in der umgebenden Landschaft haben den Artenreichtum bodenlebender Spinnen sowohl in ökologisch als auch in konventionell bewirtschafteten Weizenfeldern von durchschnittlich 12 auf 20 Arten pro Feld erhöht. Der Artenreichtum der lokalen Gemeinschaft wurde also vor allem von dem in der Landschaft vorhandenen Artenpool bestimmt. Die Aktivitätsdichte hing dagegen hauptsächlich von der lokalen Bewirtschaftung ab und lag in ökologischen Feldern 62\% höher als in konventionellen. Außerdem korrelierte die Aktivitätsdichte in konventionellen Feldern positiv mit dem Anteil naturnaher Lebensräume in der umgebenden Landschaft. Ökologische Felder hatten unabhängig von der Landschaftsstruktur hohe Spinnendichten, konventionelle Felder waren offensichtlich stärker auf Zuwanderung angewiesen. Folglich muss zur Förderung der Artenvielfalt bodenlebender Spinnen auf Feldern eine geeignete Landschaftsstruktur vorhanden sein, während sich die Dichten durch ökologische Bewirtschaftung steigern lassen. (Kapitel 3)

Die Abundanz von Baldachinspinnen in Weizenfeldern hing stark von der umgebenden Landschaft ab. In den Jahren 2001 und 2003 vervielfachten sich ihre Dichten im Laufe des Mai und Juni (z.B. von durchschnittlich 36 auf 131 Netze pro $\mathrm{m}^{2}$ zwischen Mitte Mai und Ende Juni 2001) und waren dabei in Landschaften mit hohem Anteil naturnaher Lebensräume höher als in Landschaften mit wenig naturnahen Lebensräumen (z.B. 130 gegenüber 18 Netze pro m² Ende Mai 2001). Im Jahr 2002 waren die Abundanzen in allen Landschaften konstant niedrig. Offensichtlich wurde die Einwanderung der Spinnen durch die Luft in diesem Jahr verhindert - wahrscheinlich durch das regnerische Wetter. (Kapitel 4) 
Aufgrund von Ausschlussexperimenten im Winterweizen verringerten fliegende Gegenspieler den Befall mit Getreideblattläusen um 51\%, während bodenlebende Prädatoren die Blattlausdichte um 31\% reduzierten. Die dominante Blattlausart war Sitobion avenae. Unter den bodenlebenden Gegenspielern dominierten zahlenmäßig die Baldachinspinnen, während die fliegenden Blattlausgegenspieler vor allem durch parasitoide Wespen (Aphidiidae) vertreten waren. Diese erreichte in den Varianten ohne Ausschlusskäfige ungewöhnlich hohe Parasitierungsraten von durchschnittlich 26\%. Die Ergebnisse zeigen, dass bodenlebende und fliegende Gegenspieler in der Lage sind, den Befall mit Getreideblattläusen zu reduzieren, und dass sich beide Gruppen in ihrer Wirkung ergänzen. (Kapitel 5)

Bei dem Ausschlussexperiment mit und ohne Mulch im Sommerweizen wurden die angesiedelten Populationen von Rhopalosiphum padi ebenfalls signifikant durch bodenlebende und fliegende Blattlaus-Gegenspieler reduziert. Bodenlebende Prädatoren den Blattlausbefall um 35\% (Juni) bzw. 29\% (Juli) verringert. In den gemulchten Varianten kamen dabei $87 \%$ mehr Spinnen und 25\% weniger Blattläuse vor als in den Varianten ohne Mulch. Ende Juli reduzierten fliegende Gegenspieler die Blattlausdichten signifikant um 48\%. Da $R$. padi kaum parasitiert war, waren wahrscheinlich die blattlausfressenden Larven von Schwebfliegen (Syrphidae) und/oder Gallmücken (Cecidomyiidae) der Gattung Aphidoletes für diesen Effekt verantwortlich. Mulch ist also geeignet, bodenlebende Blattlausgegenspieler in Weizenfeldern zu fördern und dadurch den Befall mit Getreideblattläusen zu reduzieren. (Kapitel 6)

Die in Kapitel 7 zusammengestellten Fallstudien zeigen, dass zahlreiche natürliche Gegenspieler von Schädlingen im Winterraps und Winterweizen von einem hohen Angebot naturnaher Lebensräume auf Landschaftsebene profitieren. Dabei wurde das Vorkommen von Getreideblattlaus-Parasitoiden durch den Strukturreichtum auf kleinen Skalen von 0,5 bis $1 \mathrm{~km}$ bestimmt, während die ausbreitungsstarken Baldachinspinnen noch auf die Zusammensetzung der Landschaft in 2 bis $3 \mathrm{~km}$ Entfernung reagierten. Als Folge zeitlicher Dynamik im Raps-Anbau konnte festgestellt werden, dass sich der Befall mit Glanzkäfern und ihre Parasitierung auf Feldern konzentrierte, in deren Umgebung die Raps-Anbaufläche gegenüber dem Vorjahr zurückgegangen war. Umgekehrt verringerten sich Befall und Parasitierung, wenn sich der Raps-Anteil erhöht hatte. Auch die Wirkung lokaler Maßnahmen zur Nützlingsförderung hing von der umgebenden Landschaft ab. So war eine erhöhte Parasitierung von Rapsglanzkäfern in 
der Nähe von Randstreifen nur in ausgeräumten Landschaften festzustellen, während die Parasitierungsraten in strukturreichen Landschaften unabhängig vom lokalen Vorhandensein von Randstrukturen gleichmäßig hoch waren. Trotz der erhöhten Nützlingsvorkommen wurde in Weizenfeldern mit strukturreicher Umgebung kein reduzierter Blattlaus-Befall festgestellt - möglicherweise, weil nicht nur die Gegenspieler, sondern zunächst auch die Blattläuse selbst vom Angebot naturnaher Lebensräume in der Landschaft profitieren, denn auch Getreideblattläuse überwintern überwiegend außerhalb der Felder. Insgesamt zeigen die Untersuchungen deutlich, dass im Ackerbau natürliche Schädlingskontrolle durch Arthropoden maßgeblich von der Zusammensetzung der Landschaft abhängt. Daher sollten Landschaftseffekte bei der Erforschung und Entwicklung biologischer Schädlingskontrolle in Zukunft stärker berücksichtigt werden. 


\title{
The role of perennial habitats for Central European farmland spiders
}

\begin{abstract}
Spiders are important predators of insect pests. Some species invariably dominate spider communities in crop fields over large parts of Europe, and are therefore considered as "agrobionts". It is however not clear if these species generally prefer arable habitats, or to what degree they utilize other habitats during times when crops are inhospitable. Here, spider abundances in 26 crop fields and 16 perennial habitats in Germany were compared during spring. Overall spider abundance in winter wheat was $75 \%$ lower than in perennial habitats, and species richness was reduced by $46 \%$. Out of a total of 91 species, 73 had higher densities in perennial habitats, including the most dominant crop spiders Erigone atra and Tenuiphantes tenuis. Only one species (Oedothorax apicatus) was significantly more abundant in crops than in perennial habitats. Hence, the high dominance of most "agrobiont" species in crops was due to low densities of other species, and not to their own higher abundances. Therefore, perennial habitats adjacent to crop-fields could enhance spider populations and their potential for biological control in arable fields on a landscape level.
\end{abstract}

Key-words: Araneida, habitat preference, disturbance, dispersal, arable crop, fallow, grassland, winter wheat

\section{Introduction}

Spiders (Araneida) are abundant, species-rich predators in European crop fields (Sunderland et al. 1997, Marc et al. 1999, Nyffeler and Sunderland 2003) and contribute to the control of agricultural pests (Symondson et al. 2002, Lang 2003, Schmidt et al. 2003). Typically, few spider species achieve exceptional dominance on arable land, and these have been described as agrobionts (Luczak 1979, Blick et al. 2000, Samu and Szinetár 2002). Four species of Linyphiidae (Erigone dentipalpis, Meioneta rurestris, Oedothorax apicatus and Tenuiphantis tenuis) and Pachygnatha degeeri (Tetragnathidae) have been identified as the core arable agrobionts for Central / Northwest Europe (Samu and Szinetár 2002). Their lower dominance in natural and secondary grasslands has been interpreted as a lower preference for these habitats, compared to arable fields. However, abundance may be more relevant than dominance, given the substantial variation of overall spider densities (Nyffeler \& Sunderland 2003). 
Also, the sheet-web weaving spiders that dominate in crops are poorly represented in pitfall trap samples (Topping and Sunderland 1992), on which current analyses of habitat specificity for European spiders are predominantly based (Hänggi et al. 1995, Blick et al. 2000, Bolaños 2003). Hence, there is a need to directly compare abundances to assess the importance of different habitats to farmland spiders, and to reveal the impact of land cover on the spider community. As farmland spiders are very mobile and potentially switch between habitat types, interactions between different habitat types may affect spider population dynamics on a landscape scale (Halley et al. 1996, Wissinger 1997, Topping 1999, Landis et al. 2000, Samu et al. 1999, Sunderland and Samu 2000). When crop spiders are more abundant in other habitats, then the composition of the landscape could retroact on crops. Densities during spring are of particular interest, because crop fields are ill-suited for overwintering and recolonization may therefore depend on immigration of spiders from other habitats (Luczak 1979, Booij et al 1996, Marc et al. 1999).

To reveal the role of perennial habitats for farmland spiders, this study compares spider densities among 26 crop fields and 16 nearby perennial habitats during spring. The main questions were:

(1) How do spider communities differ between agricultural habitats?

(2) Which species that dominate in crop fields occur also in perennial habitats, and at which abundances? 


\section{Materials and methods}

Study sites

Spiders were studied in eighteen fields of winter wheat (Triticum aestivum L.), eight summer crops (six of sugar beet (Beta vulgaris L.) and two of maize (Zea mays L.)), and sixteen perennial habitats, namely eleven grasslands and five fallows. The sampling sites were interspersed over a total area of $30 \times 40 \mathrm{~km}$ around the city of Göttingen, Germany, and replicates of each habitat type were at least $6 \mathrm{~km}$ apart from each other. The four habitat types formed a gradient in the intensity and timing of disturbance. Summer crops experienced tillage before the first sampling, and drilling between the first and second sampling. Vegetation was sparse prior to the third sampling. Winter wheat fields had been drilled in autumn, and received fertilizers, fungicides and herbicides during winter and spring. Some received insecticides between the second and third sampling. Most of the grasslands were fertilized permanent hay meadows, mowed three times per year. Two grasslands were mowed once, and then grazed with cattle, and one was a permanent pasture. Fallows were the least disturbed habitat, only mowed once in summer, the swath remaining as litter.

\section{Spider sampling}

Spiders were sampled three times throughout spring, in early April, mid May and mid June 2002, with a modified vacuum shredder powered by a two-stroke engine (Stihl SH 85, Andreas Stihl AG \& Co. KG, D-64807 Dieburg, Germany; see Stewart and Wright 1995). The $11 \mathrm{~cm}$ diameter intake nozzle was cut straight across, and a $50 \mathrm{~cm}$ long, tapering gauze bag (mesh $<0.5 \mathrm{~mm}$ ) was inserted to intercept the arthropods. Samples were transferred to white plastic trays and spiders were immediately separated out in the field. Suction sampling provides abundance data for spiders, but individuals in soil crevices or dense layers of vegetation or litter may be undersampled (Topping and Sunderland 1992, 1994a). However, as the highest spider abundances were observed in habitats with dense vegetation and litter, the results and conclusions could only have been weakened, and not caused, by any resulting bias. On each of three sampling dates, ten samples of $0.2 \mathrm{~m}^{2}$ were taken ten meters apart from each other, starting $20 \mathrm{~m}$ from one corner of each habitat. The sampling areas were enclosed with a circular, $30 \mathrm{~cm}$ high plastic ring and then sampled for about one minute, lowering the nozzle two times over each point within the enclosure. Sampling was carried out in dry, warm weather. Six summer crops, five grasslands and one fallow could only be sampled twice, because 
drilling or mowing had left too much debris to extract arthropod samples. To adjust for the lower sampling intensity, species richness for these sites was multiplied by the mean ratio of species richness at three dates to species richness at two dates from the sites where samples were complete. This ratio ranged from 1.22 for summer crops to 1.25 for grasslands. Spider taxonomy followed Blick et al. (2002). As females of Oedothorax apicatus and $O$. retusus could not be distinguished in all cases, only males were analysed and their abundances multiplied with the ratio of total individuals to total males of both species.

\section{Data analyses}

Abundances were calculated by dividing the number of individuals by the area sampled and $\log 10(\mathrm{x}+1)$-transformed to obtain normality and adjust variances. The association between spider species and habitat types was visualized by performing Principal Component Analysis (PCA) on transformed spider abundances. t-tests with separate variance estimates were used to compare spider densities between crops and perennial habitats (StatSoft, Inc. 2000). The comparison-wise error rates are used, because Bonferroni corrections overly increase the rate of type II-errors (Legendre and Legendre 1998). The Bernoulli equation was used to assess if the number of significant outcomes exceeded the number that could have been expected by chance in multiple comparisons (Moran 2003). Species richness and dominance levels were based on adult individuals only. Species were considered dominant, if they accounted for more than $1 \%$ of the individuals (following Samu and Szinetár 2002). Means \pm standard errors are shown in text and figures.

\section{Results}

A total of 4700 spiders belonging to 91 species were sampled, of which 2157 were immature. Forty-seven species were found in crop fields, with Erigone atra (23.5\%), Tenuiphantes tenuis (20.1\%), Oedothorax apicatus $(14.5 \%)$, and ten other species above $1 \%$ dominance. Eighty species were found in perennial habitats. E. atra $(25.9 \%)$ and $T$. tenuis $(11.0 \%)$ were again the most dominant, and 14 other species each accounted for more than $1 \%$ of all individuals. Species are listed in Table 1, and the abundances of species with more than $1 \%$ dominance in either crop fields or perennial habitats are highlighted. 
Table 1: Abundance of spiders in $n=26$ crop fields and $n=16$ perennial habitats, in bold type for dominant species ${ }^{\mathrm{a}}$.

\begin{tabular}{|c|c|c|c|c|c|c|c|}
\hline \multirow[t]{2}{*}{ Family } & \multirow[t]{2}{*}{ Species } & \multirow[t]{2}{*}{ Abbreviation } & \multicolumn{2}{|c|}{ Individuals / $100 \mathrm{~m}^{2}$} & \multirow[t]{2}{*}{$\mathrm{t}$} & \multirow[t]{2}{*}{ d.f. } & \multirow[t]{2}{*}{$\mathrm{p}$} \\
\hline & & & crop & perennial & & & \\
\hline \multirow[t]{2}{*}{ Araneidae } & immature & Arani & $3.8 \pm 1.4$ & $15 \pm 5.5$ & 1.9 & 19.7 & 0.074 \\
\hline & Mangora acalypha & Mangacal & $1.9 \pm 1.4$ & $30 \pm 8.9$ & 4.1 & 17.5 & 0.001 \\
\hline Clubionidae & immature & Clubi & $0.6 \pm 0.6$ & $30 \pm 17$ & 2.4 & 15.5 & 0.032 \\
\hline \multirow[t]{9}{*}{ Erigoninae } & Araeoncus humilis & Araehumi & $13 \pm 3.2$ & $31 \pm 9.4$ & 1.6 & 23.2 & 0.134 \\
\hline & Collinsia inerrans & Colliner & $5.4 \pm 3.0$ & $4.7 \pm 3.4$ & -0.2 & 32.9 & 0.866 \\
\hline & Erigone dentipalpis & Erigdent & $18 \pm 5.0$ & $56 \pm 15$ & 2.1 & 22.8 & 0.043 \\
\hline & Erigonella hiemalis & Erighiem & $0.6 \pm 0.6$ & $65 \pm 42$ & 2.5 & 15.3 & 0.024 \\
\hline & immature & Erigi & $197 \pm 44$ & $1134 \pm 191$ & 6.5 & 33.2 & $<0.001$ \\
\hline & Micrargus herbigradus & Micrherb & $3.5 \pm 1.5$ & $19 \pm 9.6$ & 1.5 & 18.1 & 0.147 \\
\hline & Micrargus subaequalis & Micrsuba & $1.9 \pm 1.1$ & $84 \pm 57$ & 3.0 & 15.8 & 0.009 \\
\hline & Tiso vagans & Tisovaga & $1.9 \pm 1.1$ & $205 \pm 80$ & 4.3 & 15.4 & 0.001 \\
\hline & Troxochrus scabriculus & Troxscab & $2.6 \pm 1.5$ & $17 \pm 8.6$ & 1.5 & 17.8 & 0.145 \\
\hline \multirow[t]{6}{*}{ Linyphiinae } & Bathyphantes gracilis & Bathgrac & $50 \pm 11$ & $151 \pm 37$ & 2.4 & 24.2 & 0.024 \\
\hline & Centromerita bicolour & Centbico & $0.0 \pm 0.0$ & $9.4 \pm 3.4$ & 2.9 & 15.0 & 0.011 \\
\hline & immature & Linyi & $54 \pm 11$ & $484 \pm 117$ & 7.6 & 28.6 & $<0.001$ \\
\hline & Meioneta rurestris & Meiorure & $16 \pm 3.8$ & $7.8 \pm 5.0$ & -1.9 & 34.2 & 0.070 \\
\hline & Porrhomma microphthalmum & Porrmicr & $29 \pm 6.5$ & $14 \pm 5.9$ & -1.7 & 36.4 & 0.104 \\
\hline & Tenuiphantes tenuis & Tenutenu & $108 \pm 21$ & $238 \pm 45$ & 2.4 & 28.2 & 0.026 \\
\hline \multirow[t]{2}{*}{ Lycosidae } & immature & Lycoi & $5.8 \pm 2.4$ & $229 \pm 29$ & 12.3 & 21.4 & $<0.001$ \\
\hline & Pardosa palustris & Pardpalu & $1.0 \pm 1.0$ & $55 \pm 18$ & 4.1 & 15.7 & 0.001 \\
\hline Theridiidae & Theridion impressum & Therimpr & $8.3 \pm 3.6$ & $1.0 \pm 1.0$ & -1.9 & 33.6 & 0.062 \\
\hline \multirow[t]{2}{*}{ others $^{b}$} & adult & & $21 \pm 3.8$ & $207 \pm 44$ & & & \\
\hline & immature & & $0.6 \pm 0.6$ & $54 \pm 30$ & & & \\
\hline
\end{tabular}

${ }^{a}$ Species found in six or more sites.

${ }^{\mathrm{b}}$ Species found in less than six sites, with abundance (Individuals $/ 100 \mathrm{~m}^{2}$ ) in crops versus perennial habitats in brackets: Achaearanea riparia $(0.6,1)$, Aculepeira ceropegia $(0,1)$, Agroeca brunnea $(0.6,0)$, Alopecosa cuneata (0, 7.8), A. pulverulenta $(0.6,5.2)$, Anelosimus vitatus $(0.6,0)$, Argiope bruennichi $(0$, 4.2), Aulonia albimana (0,1), Bathyphantes parvulus $(0,2.1)$, Centromerus dilutus $(0,1.6)$, C. sylvaticus $(0,1)$, Clubiona diversa $(0,2.1)$, C. lutescens $(0,2.1)$, C. neglecta $(0,3.1)$, C. reclusa $(0.6,8.3)$, Cnephalocotes obscurus (0, 4.7), Diplostyla concolor (0.6, 1.6), Diplocephalus latifrons (0.6, 2.6), Dismodicus bifrons (0, 21.9), Enoplognatha ovata (0, 5.7), Eperigone trilobata (0, 1.6), Episinus angulatus (0, 1), Ero cambridgei $(0,2.1)$, immature Gnaphosidae $(0.6,5.2)$, Gongylidiellum latebricola $(1.9,1)$, G. vivum $(1.9,13.5)$, Heliophanus flavipes $(0,2.1)$, Hypsosinga sanguinea (0, 2.1), Lepthyphantes ericaeus $(0,11.5)$, L. insignis $(0,1.6)$, Leptorhoptrum robustum $(0.6,3.6)$, immature Liocranidae $(0,1)$, Meioneta affinis $(0,22.4)$, M. saxatilis $(0,1)$, Microlinyphia pusilla $(1.3,5.2)$, immature Mimetidae (0, 1), Ozyptila simplex (0, 2.1), Pachygnatha listeri (0, 1), Paidiscura pallens (1.6, 0), Panamomops sulcifrons (0, 20.8), Pardosa amentata (0.6, 1), Pelecopsis parallela (0, 1.6), Phrurolithus festivus $(0,1)$, P. minimus $(0,2.1)$, Pisaura mirabilis $(0,2.6)$, Pocadicnemis pumila $(0,3.6)$, Porrhomma errans $(0,1)$, P. oblitum $(0.6,0)$, Robertus lividus $(0.6,0)$, immature Salticidae $(0,7.3)$, Sintula corniger $(0.6,0)$, Tallusia experta $(0,1)$, Tapinocyba pallens $(0.6,0)$, T. praecox $(0,1)$, Tenuiphantes zimmermanni $(0,1)$, Tetragnatha pinicola $(1.9,0)$, immature Thomisidae $(0,38.5)$, Tibellus oblongus $(0.6,0)$, Trochosa ruricola $(0,1.6)$, T. terricola $(0,1)$, Walckenaeria atrotibialis $(0,1), W$. dysderoides $(0,3.6), W$. nudipalpis $(1.3,3.6), W$. unicornis $(0,3.1), W$. vigilax $(1.9,0)$, Xysticus cristatus $(0,4.2)$, X. kochi $(0.6,0), X$. ulmi $(0,2.1)$, Zora spinimana $(0,1)$, immature Zoridae $(0,1)$. 


\section{Distribution of species across habitats}

Figure 1 shows the Principal Component Analysis of spider assemblages at the 42 sites. All crop fields (triangles) form a distinct group with low values on axis one. The perennial habitats (circles) have positive values on axis one, and scatter along axis two. As is also shown by the species plot, the majority of spiders had higher abundances in the perennial habitats (73 out of 91 species; sign test: $Z=5.66 ; p<0.001$ ). Thus, crop fields were characterized by low densities of most species. This was even more apparent for the summer crops (filled triangles), which are grouped at the left of the crop fields. The scatter of perennial habitats along axis two largely divides fallows (filled circles) from grasslands (open circles). The grassland that groups with the fallows at the very top of axis two was the only permanent pasture, with the least intensive management among the grasslands and a succession towards scrubs. The overall most numerous spider - Erigone atra (Erigoninae) - was more abundant in perennial habitats with marginal significance (t-test: $\mathrm{p}=0.065)$. Spiders with significant preference for perennial habitats were Mangora acalypha (Araneidae), Dicymbium nigrum, Erigone dentipalpis, Erigonella hiemalis, Micrargus subaequalis, Oedothorax fuscus and Tiso vagans (Erigoninae), Bathyphantes gracilis, Centromerita bicolor and Tenuiphantes tenuis (Linyphiinae), Pardosa palustris and P. pullata (Lycosidae), Pachygnatha degeeri (Tetragnathidae), and immatures of Erigoninae, Linyphiinae, Lycosidae and Tetragnathidae (Table 1). Species that dominated in crop fields had their highest abundances in grasslands rather than in fallows (e.g. E. atra, E. dentipalpis \& B. gracilis; Fig. 1). Oedothorax apicatus (Erigoninae) was the only species that had significantly higher abundances in crops than in perennial habitats. Meioneta rurestris, Porrhomma microphthalmum (Linyphiinae), and Theridion impressum (Theridiidae) showed a trend to prefer arable fields (marginally significant). Overall, 18 out of 33 comparisons of species abundances revealed significant differences, which exceeds the number that could have been expected by chance $(\mathrm{p}<0.0001$ according to Bernoulli equation). 

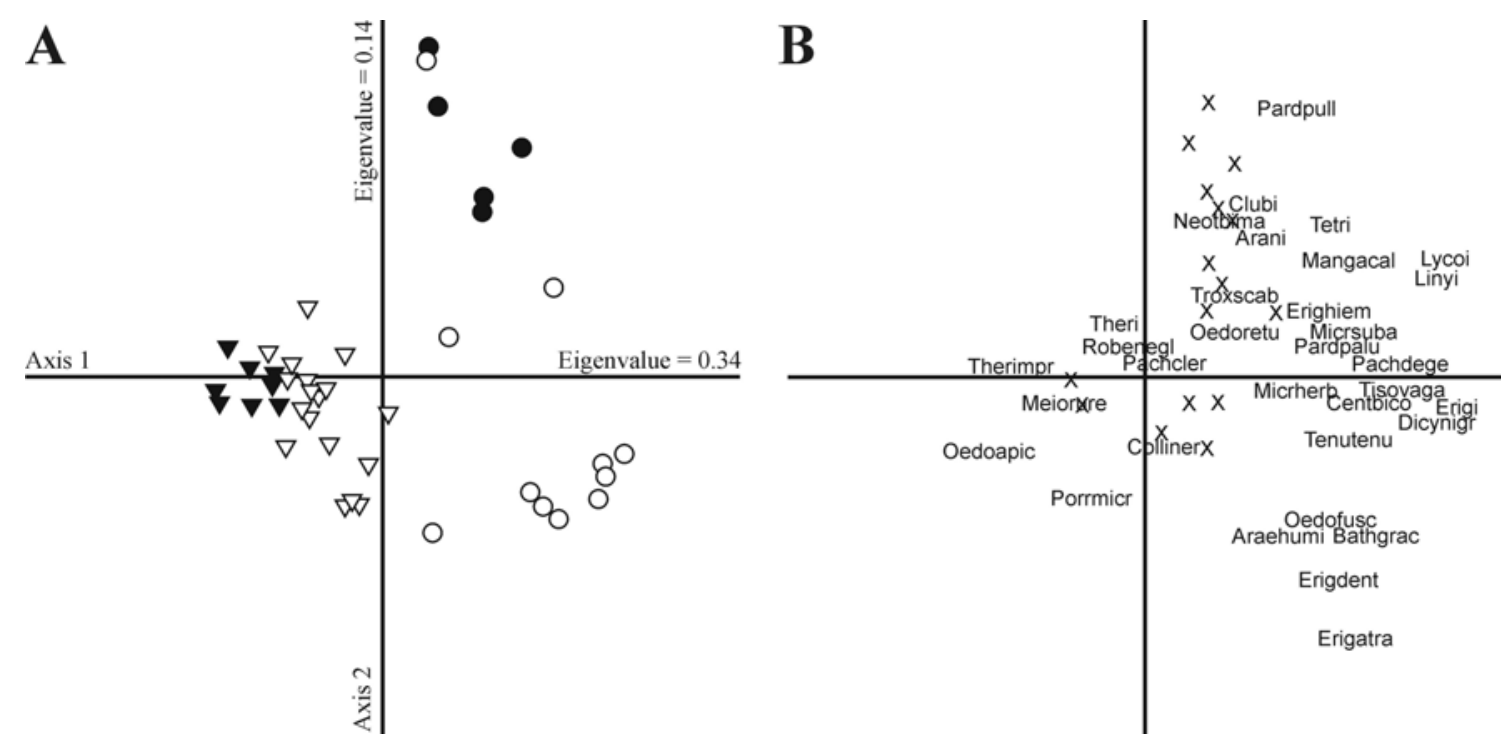

Figure 1: Ordination (PCA) of A) 42 open habitats with B) 57 spider species occurring in at least three of them. Species with six or more occurrences are labelled (for abbreviations see Table 1), others are represented by an X. Filled triangles $=$ summer crop; open triangles $=$ winter wheat; open circles $=$ grassland; filled circles $=$ fallow .

\section{Families and diversity}

Seven out of eight spider families were significantly less abundant in crops than in perennial habitats (Table 2). Densities of web-building families were reduced by $89 \%$ (Araneidae), $81 \%$ (Erigoninae), $73 \%$ (Linyphiinae) and $82 \%$ (Tetragnathidae) The abundance of cursorial Clubionidae, Lycosidae and Thomisidae was reduced by $97 \%$, $98 \%$ and $99 \%$ in crops, respectively. Although the dominance of Linyphiidae (Erigoninae plus Linyphiinae) was stronger in crops ( $88 \%$ of all spiders in crops) than in perennial habitats ( $78 \%$ of all spiders in perennial habitats), their density in crops was only about one fifth of that in perennial habitats. Figure 2 shows the overall abundance (Fig. 2A) and species richness (Fig. 2B) of spiders in summer crops, winter wheat, grasslands and fallow. Spider abundance was $89 \%$ lower in summer crops, and $75 \%$ lower in winter wheat than in grasslands and fallows (ANOVA: $F_{3,38}=61.9, \mathrm{p}<$ 0.001). Differences between spider abundances in the two types of perennial habitat were not significant. Species richness was reduced by $67 \%$ in summer crops, and by 46 $\%$ in winter wheat compared to grasslands and fallows (ANOVA: $F_{3,38}=50.0, \mathrm{p}<$ 0.001). The difference in species richness between the two perennial habitat types was again not significant. 
Table 2: Abundance of spider families with more than 6 occurrences in $n=26$ crop fields and $n=16$ perennial habitats.

\begin{tabular}{lccccc}
\hline Family & \multicolumn{2}{c}{ Individuals $/ 100 \mathrm{~m}^{2}$} & $\mathrm{t}$ & d.f. & $\mathrm{p}$ \\
\cline { 2 - 4 } & crop & perennial & & & \\
\hline Araneidae & $5.8 \pm 1.8$ & $53 \pm 13$ & 4.9 & 19.6 & $<0.001$ \\
Clubionidae & $1.3 \pm 0.9$ & $46 \pm 23$ & 3.1 & 15.7 & 0.007 \\
Erigoninae & $476 \pm 73$ & $2517 \pm 371$ & 6.6 & 30.0 & $<0.001$ \\
Linyphiinae & $261 \pm 34$ & $957 \pm 168$ & 6.0 & 29.6 & $<0.001$ \\
Lycosidae & $8.7 \pm 3.3$ & $541 \pm 127$ & 10.8 & 19.4 & $<0.001$ \\
Tetragnathidae & $30 \pm 7.0$ & $171 \pm 44$ & 5.6 & 31.9 & $<0.001$ \\
Theridiidae & $49 \pm 9.4$ & $87 \pm 29$ & 0.7 & 24.1 & 0.482 \\
Thomisidae & $0.6 \pm 0.6$ & $47 \pm 25$ & 2.4 & 15.3 & 0.027 \\
\hline
\end{tabular}
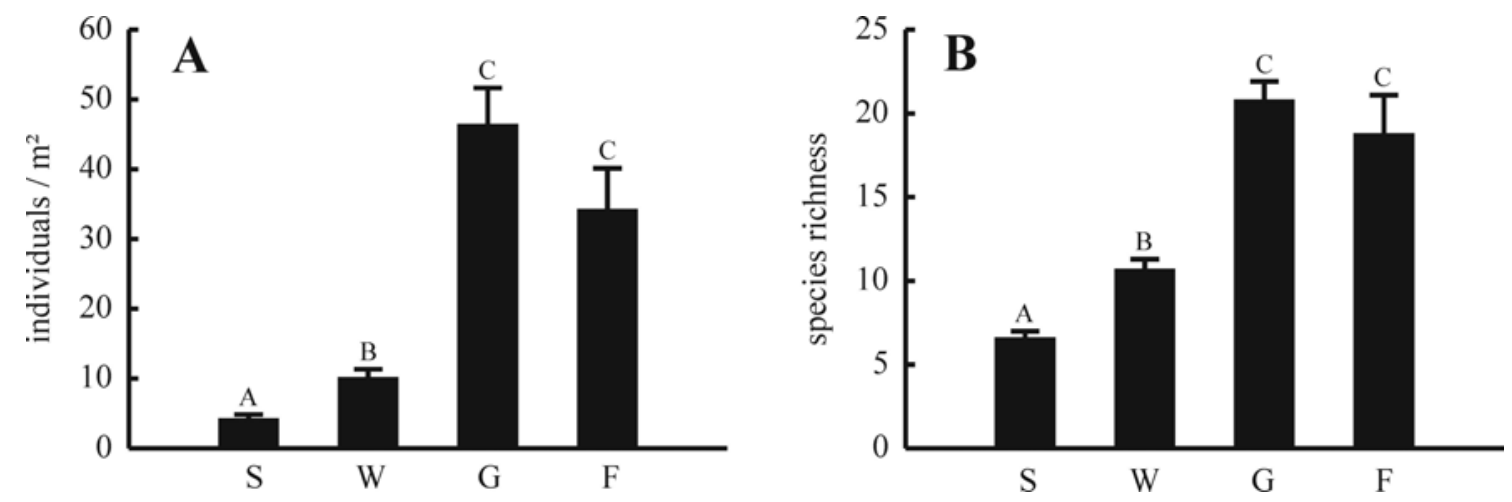

Figure 2: A) Abundance and B) species richness of spiders in summer crops (S), winter wheat (W); grassland $(\mathrm{G})$ and fallow (F). ANOVA: $F_{3,38}=61.9, \mathrm{p}<0.001$ (abundances) and $F_{3,38}=50.0, \mathrm{p}<0.001$ (species richness). Letters above columns indicate groups significantly different from each other according to Scheffé - tests.

\section{Discussion}

Spider communities clearly differed between habitat types. Abundance and species richness in crop fields were only a fraction of those in perennial habitats. The sparseness in arable fields was much stronger for the cursorial families Clubionidae, Lycosidae and Thomisidae than for web-builders (Araneidae, Linyphiidae, Tetragnathidae). Linyphiidae had relatively high densities in crops, but even they were 4.7 times more abundant in grasslands and fallows. Relatively high densities of Linyphiidae have also been observed in dune ecosystems disturbed by grazing, mowing or inundation, (Bonte et al. 2002) and in Phragmites reed beds disturbed by winter cutting (M.H.S., unpublished data). Hence, it appears that disturbance either affects the large, cursorial spider families more than small web-builders, or that small web builders recover faster through immigration. Tillage, and the resulting bare soil surface, is likely the factor that 
makes arable habitats less suitable for spiders during winter, as most spiders need dry shelter within vegetation or litter for overwintering (Wise 1993, Booij et al. 1996).

Species with higher abundances in perennial habitats than in crops included Erigone atra, E. dentipalpis, Bathyphantes gracilis, Tenuiphantes tenuis and Pachygnatha degeeri, which together made up $56 \%$ of the crop spider community. Thus, the spider community in crops was composed substantially of species that had higher abundances in perennial habitats during spring. This pattern suggests that a mosaic of crops and perennial habitats is superior to arable crops alone for most "agrobionts", despite their clearly higher dominance in crops according to pitfall trap data (Hänggi et al. 1995, Samu and Szinetár 2002, Bolaños 2003). In the current study, the higher dominance of most linyphiids in crops is due to the absence of other spider species, and not due to preference for that habitat. Instead, species such as Erigone atra and Tenuiphantes tenuis seem to either prefer perennial habitats generally, or switch between perennial and annual habitats in the course of the year. Evidence for such alternating exchanges between habitat types is scarce. However, higher linyphiid densities and emigration rates in senescing crops than in grasslands during summer, and vice versa during other times of the year, suggest that such an exchange exists (Thomas and Jepson 1997, 1999). Models have already demonstrated how spider populations could benefit from the inclusion of other landscape elements during times when crops are subject to disturbance (Topping and Sunderland 1994b, Halley et al. 1996, Topping 1999). During times with little disturbance, arable crops may be superior to perennial habitats due to reduced intraguild interference, which is important for spider population limitation (Riechert and Lockley 1984, Wise 1993). Abundant food (e.g. aphids) may be an additional factor (Harwood et al. 2001), but quantitative comparisons among crops and perennial habitats are scarce (Nyffeler and Benz 1988).

The money spider Oedothorax apicatus was the only species with significantly higher abundances in crops than in perennial habitats. However, even this species has not been found overwintering in crop fields in the study area during three subsequent years (Dinter 1997). An explanation for its high densities in crops already during spring may be the more cursorial dispersal of that species. This enables it to move from overwintering sites to summer habitats earlier in the year (Thomas et al. 1990, Lemke and Poehling 2002). In contrast to E. atra, T. tenuis and B. gracilis, O. apicatus is rarely found ballooning (Thomas et al. 1990, Dinter 1997). Ballooning spiders are able to 
cover larger distances (Thomas et al. 2003), but ballooning in early spring is probably not as far-reaching as in summer for meteorological reasons (Toft 1995). As O. apicatus leaves crop fields cursorially, it can accumulate in nearby overwintering habitats, and return into crops as early as March (Dinter 1997). Lemke and Poehling (2002) observed a successive increase of $O$. apicatus densities in wheat 7.5 and $15 \mathrm{~m}$ adjacent to sown weed strips starting in March. In contrast, no such movements could be observed for the presumably more aerially dispersing E. atra, which had also overwintered in large numbers in the weed strips. Further, O. apicatus appeared to be more tolerant of sparsely vegetated soil than other species, and may be abundant even in sugar beet and maize fields (Dinter 1997). As cursorial species from other families (e.g. Lycosidae) do not enter crops in equally high numbers during spring, O. apicatus seems to demonstrate particular preference for arable habitats.

\section{Conclusion}

Overall, this study shows the importance of perennial habitats for farmland spiders, including species that dominate in arable crops. With the exception of Oedothorax apicatus, high dominance levels of "agrobionts" in fields were due to low densities of other species, and not to their higher abundances compared to perennial habitats. Therefore, it appears questionable whether arable fields alone are able to sustain abundant, species-rich spider communities. Perennial open habitats have the potential to increase spider populations on a landscape scale and could enhance spider abundances in arable fields. As spiders are able to reduce herbivore numbers (Symondson et al. 2002, Lang 2003, Schmidt et al. 2003), their enhancement could contribute to natural pest control, an important ecosystem service for sustainable agriculture.

\section{Acknowledgments}

The authors would like to thank Oliver-David Finch and Theo Blick for checking spider identifications, and all farmers who provided access their fields. Örjan Östman, George Thomas, Jason Tylianakis and two anonymous reviewers gave valuable comments on earlier drafts of the manuscript. M.H.S. was supported by the German National Academic Foundation (Studienstiftung des deutschen Volkes). 


\title{
Landscape context affects the diversity, and local management the density of farmland spiders
}

\begin{abstract}
Landscape diversification and organic farming are two options to enhance biodiversity and biological control agents, and thereby increase agricultural sustainability. We tested impacts of landscape and management on farmland spiders in twelve pairs of organic versus conventional wheat fields along a gradient of landscape complexity $(13 \%-69 \%$ non-crop). High percentages of non-crop habitats enhanced species richness irrespective of local management (from 12 to 20 species). This indicates larger species pools in complex landscapes, presumably caused by higher availability of refuge and overwintering habitats. Organic management did not increase species richness, but enhanced activity density by $62 \%$, probably by providing more shelter and/or food through weediness and organic manure. Additionally, activity density was positively related to the percentage of non-crop habitats in the surrounding landscape, but only in conventional fields. In conclusion, while organic farming can successfully enhance spider abundances, prospects of agri-environment schemes are limited as long as they do not take the landscape context into account, which drives local diversity.
\end{abstract}

\section{Introduction}

Communities depend on local conditions, and can additionally be influenced by the regional occurrence of resources or immigrants (Ricklefs 1987). The role of the landscape context in structuring animal communities is increasingly recognized, and may be particularly important in highly dynamic habitats such as annual crops (Kareiva and Wennegren 1995, Weibull and Östman 2003, Westphal et al. 2003, Tscharntke and Brandl 2004). A major threat to biodiversity is the expansion of intensive arable crops that has occurred in many European landscapes during the past decades, leaving structurally simplified landscapes with little non-crop habitat (Stoate et al. 2001, Benton et al. 2003). Nevertheless, landscape effects on invertebrate species richness in farmland remained little explored (Krebs et al. 1999). Recent exceptions are the positive effects of landscape complexity on species richness of butterflies and ground beetles (Weibull and Östman 2003), and on trap-nesting bees and wasps (Steffan-Dewenter 2002). Complex landscapes with high habitat diversity can be expected to provide larger species pools than simple landscapes. Exchange of species that use multiple habitats 
during their life cycle can generate higher species richness in such complex landscapes (Zobel 1997, Srivastava 1999). In agricultural landscapes, refuge habitats are of major importance for many arthropod populations during times when crops are disturbed (Landis et al. 2000, Sunderland and Samu 2000), and many spider (Araneida) species that are typical of crops during summer, overwinter predominantly in non-crop habitats (Marc et al. 1999, MHS unpublished work). Models demonstrate how spider abundances can be enhanced by non-crop habitats on a landscape scale after events such as pesticide applications (Topping and Sunderland 1994, Halley et al. 1996, Topping 1999). Hence, diversity and/or abundance may benefit from structurally complex landscapes.

Organic farming may promote beneficial invertebrates by omitting synthetic pesticides and mineral fertilizers. While the positive impact on arable weeds is well documented (Menalled et al. 2001, Hyvonen and Salonen 2002), effects on arthropods often remain ambiguous or show less pronounced effects than expected (Glück and Ingrisch 1990, Booij and Noorlander 1992, Feber et al. 1998, Moreby et al. 1994, Pfiffner and Luka 2003, Weibull and Östman 2003). However, Pfiffner and Niggli (1996) pitfall-trapped $108 \%, 97 \%$ and $161 \%$ more spider individuals in organic than in conventional fields during three years. They found similar patterns in ground beetle (Coleoptera: Carabidae) and rove beetle numbers (Coleoptera: Staphylinidae), but did not test for differences in species richness. Therefore, further investigations on the effects of organic farming on arthropods are needed. In particular, it is poorly known if landscape effects differ between conventional and organic management (Östman et al. 2001). Landscape effects may be stronger in conventional fields because they depend more on immigration, or in organic fields because they can take up more immigrants. Here, we tested the relative impact of landscape and management on spiders in winter wheat fields using a paired-field approach along a gradient of landscape complexity, testing which properties of the spider community are determined at the local and at the landscape scale. 


\section{Materials and methods}

In the study region around the city of Göttingen (Germany), twelve non-overlapping landscape sectors of $1.5 \mathrm{~km}$ radius were chosen along a gradient from structurally simple, with $>80 \%$ arable land, to structurally complex, with $>50 \%$ non-crop habitats. Simple and complex landscapes were geographically interspersed. In each landscape sector, one conventionally and one organically managed winter wheat field (according to European Union Regulation 2092/91/EEC) were chosen, thus avoiding differences in landscape context between the two management forms. The percentage of non-crop habitats within a radius of $1.5 \mathrm{~km}$ around the study fields was calculated as a measure of landscape complexity, based on official digital thematic maps (ATKIS - Digitales Landschaftsmodell 25/1; Landesvermessung und Geobasisinformation, Hannover, Germany 1991-1996). Arable land covered on average 58.6\%, and non-crop habitats comprised all other habitats: mostly forest (21.5\%), grassland (12.7\%) and settlement (5.6\%, including gardens). Spiders were captured with four pitfall traps per field, arranged in a square of $10 \times 10 \mathrm{~m}$, two traps 15 and $25 \mathrm{~m}$ from a grassy field edge, respectively. The traps consisted of $0.5 \mathrm{~L}$ plastic cups with openings of $8.8 \mathrm{~cm}$ diameter. $3 \mathrm{~cm}$ beneath the opening, pieces of $2 \mathrm{~cm}$ mesh hardware cloth were inserted to prevent vertebrates from entering. Each trap was filled with $0.12 \mathrm{~L}$ of a mixture (1:2) of ethylene glycol (antifreeze) and water plus a few drops of detergent and protected from rain with $25 \times 25 \mathrm{~cm}$ acrylic glass roofs. The traps were operated twice for fourteen days, starting on May 8th, 2002 and June 28th, 2002, similar to the sampling scheme suggested by Duelli et al. (1999) for collecting the maximal proportion of a full season catch with minimal effort. Catches were transferred to $80 \%$ ethanol. As pitfall trap catches reflect a combination of each species' abundance and disposition to get trapped (largely determined by walking activity), we term the numbers of individuals captured per field 'activity densities', assuming that they reflect between-field differences in absolute densities (Topping and Sunderland 1992). Adult spiders were identified to species, and juveniles to family, the nomenclature following Blick et al. (2002). Females of Oedothorax apicatus and $O$. retusus were not distinguished. Species richness was calculated using only adult individuals. Effects of (i) conventional versus organic management and (ii) the percentage of non-crop habitats in the surrounding landscape on species richness and activity density were analysed with general linear models (SAS proc mixed, SAS institute, Cary, NC, USA), using the two sampling periods as repeated measures and the landscapes (1-12) as random blocking factor. Non-significant 
interactions were backward eliminated. At the species level, increased probabilities of falsely rejecting null hypotheses in multiple comparisons were avoided by considering Bonferroni corrections, and by calculating the overall probability for the observed incidence of outcomes falling below the nominal significance level $\alpha=0.05$ with Bernoulli equations (Moran 2003). Averages \pm standard errors are given in text and figures.

\section{Results}

8013 spider individuals from 69 species were sampled, 7911 of which were adult. The number of individuals captured per species in conventional and organic fields is given in the appendix. Activity densities were $62 \%$ higher in organic than in conventional fields (Fig. 1, Table 1). Additionally, activity density in conventional fields during May was positively correlated to the percentage of non-crop habitats (conventional $\mathrm{Y}=85+$ 1.86 X, $\mathrm{r}=0.70, \alpha=0.012$, organic $\mathrm{Y}=228+0.47 \mathrm{X}, \mathrm{r}=0.09, \alpha=0.78$ ), as manifested by the date $\times$ non-crop interaction in the global test (Table 1). In contrast, species richness was related to the percentage of non-crop habitats in the surrounding landscape (Fig. 2), but only in May, as reflected by the date $\times$ non-crop interaction (Table 1).

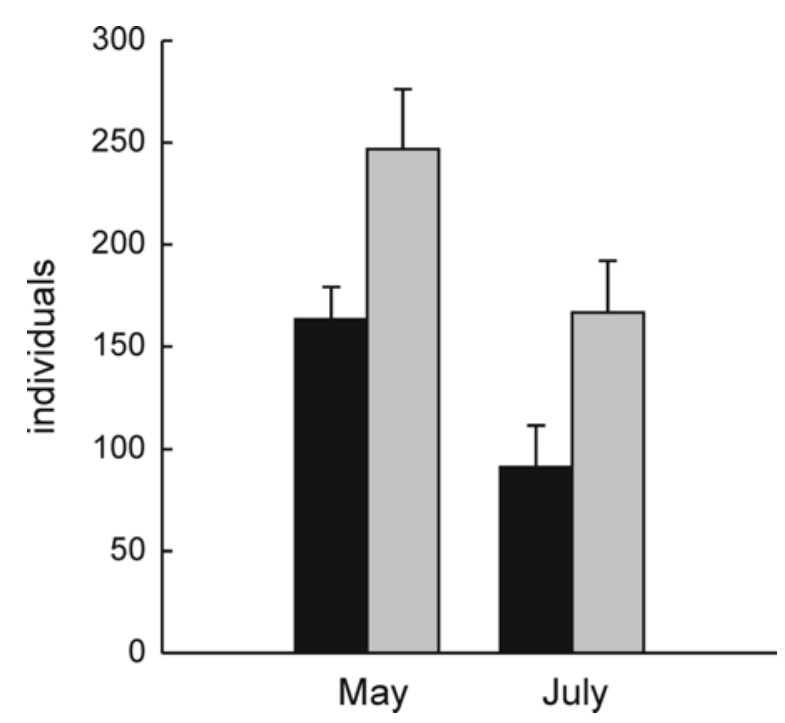

Figure 1: Spider activity density in conventional (black bars) versus organic (grey bars) winter-wheat fields in May (left) and July (right). Significantly more spiders were captured in organic fields (Table 1). 

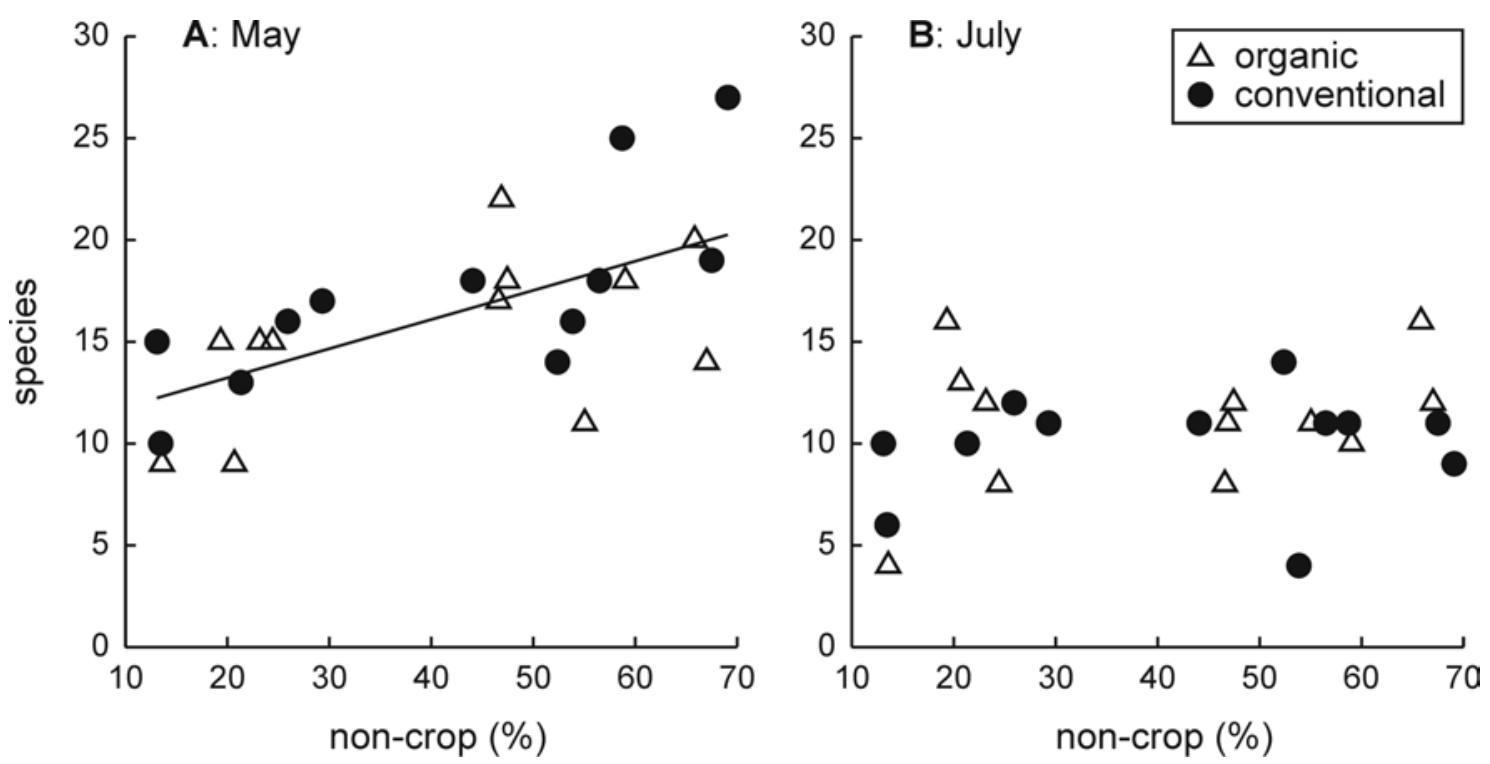

Figure 2: Correlations between the percentage of non-crop habitats and spider species richness. A: Species richness in May was positively correlated to the percentage of non-crop habitats irrespective of management $(\mathrm{Y}=10.4+0.14 \mathrm{X}, \mathrm{r}=0.63, \alpha=0.001$; global test: Table 1$)$. B: Species richness in July was not significantly related to the percentage of non-crop habitats $(r=0.19$, n.s.)

Table 1: General linear models (SAS proc mixed) on effects of conventional versus organic management, the percentage of non-crop habitat in the surrounding landscape, and sampling date on activity density and species richness of spiders in winter wheat fields.

\begin{tabular}{llccc}
\hline & Factor & d.f. & F & p \\
\hline Activity density & management & 10 & 16.44 & 0.002 \\
& date & 11 & 0.14 & 0.71 \\
& management $\times$ date & - & - & - \\
& non-crop & 11 & 0 & 0.99 \\
& non-crop $\times$ management & - & - & - \\
& non-crop $\times$ date & 11 & 6.36 & 0.028 \\
\hline Species richness & management & 10 & 0.19 & 0.67 \\
& date & 11 & 0.22 & 0.65 \\
& management $\times$ date & - & - & - \\
& non-crop & 11 & 7.74 & 0.018 \\
& non-crop $\times$ management & - & - & - \\
& non-crop $\times$ date & 11 & 5.26 & 0.043 \\
\hline
\end{tabular}

In spite of this clear pattern at the community level, there were no significant effects of landscape or management at the species level. A sign test did not indicate that a majority of all 69 species would have had higher abundances under either management $(Z=0.38, p=0.7)$. Using t-tests for matched pairs for the 27 species with six or more occurrences, three species appeared to have different numbers under organic than conventional management $(\alpha<0.05)$. Yet, this is not significant according to the Bernoulli equation $(\mathrm{p}=0.15)$, and the individual $\alpha$-levels do not sustain Bonferroni corrections. In descriptive terms, the overall higher activity densities in organic than in 
conventional fields were largely attributable to the higher numbers of Oedothorax spp. females $(\mathrm{t}=-3.3, \alpha=0.008)$ and of wolf spiders (e.g. Pardosa amentata: $\mathrm{t}=-2.6, \alpha=$ 0.024; see Appendix). In correlations between activity densities and the percentage of non-crop habitats, two out of 27 species showed $\alpha$ levels below 0.05 (Bathyphantes gracilis: $\mathrm{n}=12, \mathrm{r}=0.68, \alpha=0.015$; Trochosa terricola: $\mathrm{n}=12, \mathrm{r}=0.75, \alpha=0.005$ ). This frequency could again be expected by chance $(\mathrm{p}=0.39)$, and $\alpha$-levels do not sustain Bonferroni corrections.

\section{Discussion}

The impacts of landscape context and local management on spiders in cereal fields were differentiated in this study. The landscape context affected species richness irrespective of management type, while organic and conventional fields differed exclusively in activity density. Hence, the local habitat conditions were more favourable under organic management, allowing higher densities of surface-active spiders, but no additional spider species. Three mechanisms potentially enhance spider densities in organic fields. First, omitting pesticides may either directly reduce spider mortality, or increase food availability via reducing the mortality of spider prey. However, no insecticides were used in the studied conventional fields prior to the first sampling period, when the difference in activity density already existed. Therefore, insecticides alone could not have caused the observed difference. Second, spiders may benefit from higher weed populations in organic fields, which evoke higher structural complexity and hideouts at the soil surface, and potentially increase the availability of herbivore prey. Total coverage and species richness of arable weeds were $158 \%$ and $87 \%$ higher in the organic fields, respectively (IR unpublished work), potentially causing the observed difference in spider density (Sunderland and Samu 2000). Third, the use of manure in organic farming instead of predominantly mineral fertilizers in conventional fields may benefit spiders by increasing the availability of saprophagous insects such as springtails (Collembola) and midges (Diptera), which are among their most important prey groups (Alderweireldt 1994, Nyffeler 1999). Species richness was not enhanced by organic management, probably constrained by sources of immigrants in the landscape. Furthermore, only $1.7 \%$ of the arable land in the study region was organic, meaning that organic fields were mostly surrounded by conventionally managed land (Niedersächsisches Landesamt für Statistik, personal communication). Further-reaching benefits could be expected if organic farming became more widespread and spanned more continuous tracts of the agricultural landscape. 
The intermingling of organic and conventional fields may also be responsible for the similar increase in species richness with the proportion of non-crop habitats in the surrounding landscape in both management forms. Thus, spider communities in wheat fields were not saturated (Srivastava 1999, Loreau 2000), and fewer species arrived in wheat fields in crop-dominated landscapes. This suggests that fewer species exist in structurally simple landscapes (Landis et al. 2000, Sunderland and Samu 2000). Alternatively, fields could have been too isolated from source habitats to be reached by certain species, but this seems unlikely as the distances from the traps to the next grassy field margin (small-scale heterogeneity) were equal in all study sites. As is typical for pitfall traps (Topping and Sunderland 1992), our catches were dominated by wolf spiders (Lycosidae) and money spiders (Erigoninae). The species caught in the highest numbers, Oedothorax apicatus (Erigoninae), and also wolf spiders presumably walk into fields from their overwintering sites in spring (Lemke and Poehling 2002). Other important species in crops (e.g. Linyphiinae, Araneidae and Theridiidae), which were poorly represented in our samples, disperse more aerially, and may hence respond differently to the landscape context (Halley et al. 1996, Thomas et al. 2003). Additional to the landscape effect on species richness, spider activity densities in conventional fields during May were positively related to the percentage of non-crop habitats, approximating $80 \%$ higher activity densities in the most complex landscapes compared to the simplest ones. This suggests that activity densities in conventional fields were determined by landscape-wide immigration processes, while organic fields developed more self-sustained populations. All landscape effects were confined to the spring sampling, reflecting the strong contribution of wolf spiders that were caught in 37 times higher numbers in May than in July for phenological reasons.

In conclusion, both organic farming and a high percentage of non-crop habitats in agricultural landscapes enhanced spiders in wheat fields. These effects contribute to the conservation of biodiversity, and may favour agricultural productivity (Östman et al. 2003). Spiders are among the most numerous terrestrial predators, and their encouragement can improve the biological control of herbivores (Landis et al. 2000, Symondson et al. 2002). As parasitoid wasps (Hymenoptera parasitica) and ladybirds (Coleoptera: Coccinellidae) also benefit from landscape diversification, it becomes apparent that structurally complex landscapes host generally more biological control agents (Thies and Tscharntke 1999, Elliott et al. 2002). According to our results, agrienvironment schemes may successfully enhance biological control by providing 
financial incentives for organic farming. However, the important contribution of landscape diversification is not acknowledged by these schemes, thereby reducing their potential efficiency (see Kleijn and Sutherland 2004).

\section{Acknowledgements}

We thank Christian Kluth for help with the statistics, Jason Tylianakis for linguistic advice and Oliver-David Finch and Theo Blick for checking spider identifications. Financial support came from the German Science Foundation (DFG) and the German Ministry for Research and Education (BMBF). MHS was supported by the German National Academic Foundation (Studienstiftung des deutschen Volkes).

Appendix: Spiders captured in 12 conventional and 12 organic fields (mean \pm S.E.).

\begin{tabular}{|c|c|c|c|}
\hline Family & Species & Conventional & Organic \\
\hline Dictynidae & Cicurina cicur & $0.1 \pm 0.1$ & $0.0 \pm 0.0$ \\
\hline \multirow[t]{29}{*}{ Erigoninae } & Araeoncus humilis & $0.8 \pm 0.3$ & $0.8 \pm 0.3$ \\
\hline & Ceratinella brevis & $0.1 \pm 0.1$ & $0.0 \pm 0.0$ \\
\hline & Collinsia inerrans & $0.7 \pm 0.4$ & $1.7 \pm 1.1$ \\
\hline & Dicymbium nigrum brevisetosum & $0.6 \pm 0.3$ & $0.3 \pm 0.2$ \\
\hline & Diplocephalus latifrons & $0.4 \pm 0.2$ & $0.0 \pm 0.0$ \\
\hline & Dismodicus bifrons & $0.1 \pm 0.1$ & $0.0 \pm 0.0$ \\
\hline & Erigone atra & $46.3 \pm 5.3$ & $51.1 \pm 8.6$ \\
\hline & Erigone dentipalpis & $8.2 \pm 1.5$ & $16.3 \pm 5.4$ \\
\hline & Erigonella hiemalis & $0.1 \pm 0.1$ & $0.1 \pm 0.1$ \\
\hline & Gongylidiellum latebricola & $0.1 \pm 0.1$ & $0.1 \pm 0.1$ \\
\hline & Gongylidiellum vivum & $0.1 \pm 0.1$ & $0.1 \pm 0.1$ \\
\hline & Leptorhoptrum robustum & $1.0 \pm 0.3$ & $1.6 \pm 0.8$ \\
\hline & Micrargus herbigradus & $0.2 \pm 0.1$ & $0.0 \pm 0.0$ \\
\hline & Micrargus subaequalis & $0.6 \pm 0.2$ & $0.2 \pm 0.2$ \\
\hline & Oedothorax apicatus, males & $29.7 \pm 6.3$ & $43.3 \pm 6.9$ \\
\hline & Oedothorax fuscus & $1.3 \pm 0.5$ & $4.8 \pm 2.6$ \\
\hline & Oedothorax retusus, males & $3.6 \pm 1.5$ & $4.3 \pm 1.1$ \\
\hline & Oedothorax spp., females & $66.8 \pm 19.4$ & $138.5 \pm 35.3$ \\
\hline & Parapelecopsis nemoralis & $0.1 \pm 0.1$ & $0.0 \pm 0.0$ \\
\hline & Pocadicnemis juncea & $0.0 \pm 0.0$ & $0.1 \pm 0.1$ \\
\hline & Tapinocyba insecta & $0.0 \pm 0.0$ & $0.1 \pm 0.1$ \\
\hline & Tiso vagans & $0.1 \pm 0.1$ & $0.2 \pm 0.2$ \\
\hline & Walckenaeria atrotibialis & $0.3 \pm 0.3$ & $0.3 \pm 0.1$ \\
\hline & Walckenaeria capito & $0.1 \pm 0.1$ & $0.0 \pm 0.0$ \\
\hline & Walckenaeria dysderoides & $0.1 \pm 0.1$ & $0.2 \pm 0.1$ \\
\hline & Walckenaeria nudipalpis & $0.2 \pm 0.1$ & $0.2 \pm 0.1$ \\
\hline & Walckenaeria unicornis & $0.0 \pm 0.0$ & $0.1 \pm 0.1$ \\
\hline & Walckenaeria vigilax & $1.8 \pm 0.8$ & $2.7 \pm 0.8$ \\
\hline & immatures & $0.1 \pm 0.1$ & $0.3 \pm 0.2$ \\
\hline \multirow[t]{7}{*}{ Gnaphosidae } & Drassylus lutetianus & $0.1 \pm 0.1$ & $0.0 \pm 0.0$ \\
\hline & Drassylus praeficus & $0.1 \pm 0.1$ & $0.0 \pm 0.0$ \\
\hline & Drassylus pusillus & $0.3 \pm 0.1$ & $0.1 \pm 0.1$ \\
\hline & Haplodrassus signifer & $0.2 \pm 0.2$ & $0.1 \pm 0.1$ \\
\hline & Haplodrassus umbratilis & $0.1 \pm 0.1$ & $0.0 \pm 0.0$ \\
\hline & Micaria pulicaria & $0.0 \pm 0.0$ & $0.1 \pm 0.1$ \\
\hline & Zelotes latreillei & $0.1 \pm 0.1$ & $0.0 \pm 0.0$ \\
\hline Hahnidae & Antistea elegans & $0.0 \pm 0.0$ & $0.1 \pm 0.1$ \\
\hline
\end{tabular}




\begin{tabular}{|c|c|c|c|}
\hline & Hahnia nava & $0.1 \pm 0.1$ & $0.1 \pm 0.1$ \\
\hline \multirow[t]{11}{*}{ Linyphiinae } & Bathyphantes gracilis & $2.7 \pm 0.7$ & $1.3 \pm 0.4$ \\
\hline & Centromerita bicolor & $0.2 \pm 0.2$ & $0.0 \pm 0.0$ \\
\hline & Centromerus cavernarum & $0.1 \pm 0.1$ & $0.0 \pm 0.0$ \\
\hline & Centromerus sylvaticus & $0.0 \pm 0.0$ & $0.1 \pm 0.1$ \\
\hline & Diplostyla concolor & $0.4 \pm 0.3$ & $0.0 \pm 0.0$ \\
\hline & Meioneta rurestris & $0.7 \pm 0.3$ & $0.8 \pm 0.4$ \\
\hline & Ostearius melanopygius & $0.1 \pm 0.1$ & $0.0 \pm 0.0$ \\
\hline & Porrhomma errans & $0.4 \pm 0.3$ & $0.3 \pm 0.1$ \\
\hline & Porrhomma microphthalmum & $0.8 \pm 0.3$ & $0.0 \pm 0.0$ \\
\hline & Tenuiphantes tenuis & $4.4 \pm 1.0$ & $3.9 \pm 0.8$ \\
\hline & Tenuiphantes zimmermanni & $0.1 \pm 0.1$ & $0.0 \pm 0.0$ \\
\hline \multirow[t]{14}{*}{ Lycosidae } & Alopecosa cuneata & $1.8 \pm 1.2$ & $3.4 \pm 2.8$ \\
\hline & Alopecosa pulverulenta & $4.7 \pm 1.3$ & $5.3 \pm 1.6$ \\
\hline & Pardosa agrestis & $2.2 \pm 0.8$ & $11.8 \pm 5.5$ \\
\hline & Pardosa amentata & $24.9 \pm 9.7$ & $51.7 \pm 12.4$ \\
\hline & Pardosa lugubris & $1.1 \pm 0.8$ & $0.6 \pm 0.6$ \\
\hline & Pardosa monticola & $0.0 \pm 0.0$ & $0.1 \pm 0.1$ \\
\hline & Pardosa palustris & $11.2 \pm 3.7$ & $24.3 \pm 6.2$ \\
\hline & Pardosa pullata & $9.8 \pm 3.2$ & $11.2 \pm 3.3$ \\
\hline & Pirata latitans & $0.0 \pm 0.0$ & $0.1 \pm 0.1$ \\
\hline & Pirata uliginosus & $0.1 \pm 0.1$ & $0.0 \pm 0.0$ \\
\hline & Trochosa ruricola & $3.8 \pm 0.9$ & $4.9 \pm 1.8$ \\
\hline & Trochosa spinipalpis & $0.1 \pm 0.1$ & $0.0 \pm 0.0$ \\
\hline & Trochosa terricola & $2.2 \pm 1.3$ & $1.5 \pm 0.6$ \\
\hline & immatures & $2.8 \pm 0.8$ & $4.8 \pm 1.6$ \\
\hline \multirow[t]{4}{*}{ Tetragnathidae } & Pachygnatha clercki & $4.5 \pm 1.6$ & $2.8 \pm 0.8$ \\
\hline & Pachygnatha degeeri & $10.8 \pm 2.0$ & $16.3 \pm 4.0$ \\
\hline & Tetragnatha pinicola & $0.0 \pm 0.0$ & $0.1 \pm 0.1$ \\
\hline & immatures & $0.0 \pm 0.0$ & $0.3 \pm 0.2$ \\
\hline \multirow[t]{3}{*}{ Theridiidae } & Neottiura bimaculata & $0.0 \pm 0.0$ & $0.1 \pm 0.1$ \\
\hline & Robertus lividus & $0.3 \pm 0.2$ & $0.0 \pm 0.0$ \\
\hline & Robertus neglectus & $0.1 \pm 0.1$ & $0.0 \pm 0.0$ \\
\hline \multirow[t]{3}{*}{ Thomisidae } & Xysticus cristatus & $0.2 \pm 0.1$ & $0.4 \pm 0.3$ \\
\hline & Xysticus kochi & $0.3 \pm 0.2$ & $0.0 \pm 0.0$ \\
\hline & immatures & $0.1 \pm 0.1$ & $0.0 \pm 0.0$ \\
\hline Zoridae & Zora spinimana & $0.1 \pm 0.1$ & $0.0 \pm 0.0$ \\
\hline
\end{tabular}




\section{Landscape context of sheetweb spider population dynamics in cereal fields}

\section{Summary}

1. Abundances of farmland spiders and their biological control efficiency may depend on non-crop habitats used for overwintering. We tested effects of landscape composition on sheetweb spider (Araneida: Linyphiinae) abundance in crop fields with special attention to the range of their aerial dispersal and its weather-dependence.

2. Sheetweb spider abundances in winter wheat fields were compared among 18 landscape sectors with 15 to 75 \% non-crop habitats during May and June 2001 to 2003. Landscape composition was considered at eleven spatial scales between 95 and $3000 \mathrm{~m}$ radius around the study sites.

3. In 2001 and 2003, spider abundances were enhanced by high percentages of non-crop habitats in one to three kilometres circumference (e.g. from 18 to 130 $\mathrm{m}^{-2}$ in late May 2001), and multiplied during consecutive sampling periods (e.g. from on average 36 to $131 \mathrm{~m}^{-2}$ between mid May and late June 2001).

4. Spider abundances were constantly low and unrelated to the landscape context in 2002. Immigration appeared to be inhibited by factors connected to exceptionally high amounts of rain during May.

5. Synthesis and applications: Sheetweb spiders responded to landscape composition kilometres away and the effects varied between years, demonstrating the need to consider large space and time scales to understand their population dynamics. Semi-natural habitats should be preserved to enhance these important natural enemies of crop pests and augment biodiversity in agricultural landscapes.

Key-words: Araneida, ballooning, biological control, dispersal distance, inter-annual variation, Linyphiidae, winter wheat 


\section{Introduction}

It is increasingly recognized that landscape patterns influence local population dynamics of animals (Ricklefs 1987; Kareiva \& Wennegren 1995; Östman, Ekbom \& Bengtsson 2001; Benton, Vickery \& Wilson 2003; Tscharntke \& Brandl 2004). This should apply particularly to mobile species that disperse to newly formed patches of suitable habitat one or several times during their lives. Sheetweb spiders (Araneida: Linyphiinae) are known to be highly mobile, being able to cover large distances by ballooning through the air on threads of silk (Vugts \& van Wingerden 1976; Greenstone et al. 1987; Bishop \& Riechert 1900; Suter 1999). Their abundances vary greatly between and within different farmland habitats and years. In summer, they rank among the most abundant predators in annual crops, often with more than 100 individuals per square metre (Thomas \& Jepson 1999; Nyffeler \& Sunderland 2003). In winter and spring, however, higher abundances of the same species in non-crop habitats suggest that these may be better suited for overwintering and an important source of immigrants into crops during spring (Luczak 1979; Thomas \& Jepson 1997; MHS unpublished data). Models have demonstrated how the exchange of individuals between different habitats can influence the overall population dynamics of farmland spiders (Topping $\&$ Sunderland 1994; Halley, Thomas \& Jepson 1996; Topping 1997, 1999). They predict that non-crop habitats enhance overall spider populations by providing refuges during times when crops are disturbed. Surprisingly, there seems to exist no published empirical evidence for positive effects of non-crop habitats on spider populations on a landscape scale.

A critical factor for understanding the link between landscape and population dynamics is the dispersal range of the study species. The assumed dispersal power (between 50 and $1000 \mathrm{~m}$ ) greatly affected simulated spider abundance and distribution in a cropdominated agricultural model landscape, whereby ranges of 500 and $750 \mathrm{~m}$ allowed for the maximum overall population sizes (Topping 1997). Direct measurements of the dispersal range of small ubiquist arthropods are extremely difficult and have, to the best of our knowledge, never been attempted for sheetweb spiders on farmland. Thomas, Brain \& Jepson (2003) modelled their dispersal distance from meteorology and behavioural aspects such as the observed between-flight intervals, the vertical distribution of ballooning spiders in the air and estimated rates of ascent and descent. They reasoned that sheetweb spiders could potentially disperse a mean distance of approximately $30 \mathrm{~km}$ on a summer day with $6 \mathrm{~h}$ of suitable weather. An alternative 
approach for assessing the magnitude of distances covered by arthropods that cannot be individually tracked has been used by Steffan-Dewenter, Münzenberg \& Tscharntke (2001); Steffan-Dewenter et al. (2002); Krauss, Steffan-Dewenter \& Tscharntke (2003); Thies, Steffan-Dewenter \& Tscharntke (2003) and Westphal, Steffan-Dewenter \& Tscharntke (2003). The densities of insects (Diptera, Lepidoptera, Hymenoptera) in crop-dominated landscapes were related to the availability of favoured foraging and/or overwintering habitats. By considering the landscape composition at variable scales between $250 \mathrm{~m}$ and $3 \mathrm{~km}$ around the study plot, the "functional scale" could be determined for which the correlation between insect density and landscape composition was closest. For example, solitary wild bees responded to the availability of seminatural habitats at the smallest scale of $250 \mathrm{~m}$, whereas the correlation for honey bees improved up to the largest scale of $3 \mathrm{~km}$ (Steffan-Dewenter et al. 2002).

Inter-annual variations in population dynamics of arthropods in crops and other ephemeral habitats may be determined by the intensity of immigration (Toft 1995; Elliott et al. 1998). Although the motivation of individual spiders to balloon can depend on local conditions such as food shortage, aeronautic activity in the field largely reflects ground densities (Weyman, Sunderland \& Fenlon 1994; Weyman, Jepson \& Sunderland 1995 ) and is triggered by favourable weather (Vugts \& van Wingerenden 1976; Toft 1995). In a coastal situation, low wind velocities were the best predictor for days with high aeronautic activity (Vugts \& van Wingerenden 1976). As passive particles, ballooning spiders further depend on rising air currents occurring mostly on days with clear, sunny weather after cold nights, which can be predicted by high daily temperature ranges. Ballooning is inhibited by precipitation and very low temperatures, but otherwise occurs year-round (Toft 1995; Thorbek, Topping \& Sunderland 2002).

In the study presented here, we test whether the build-up of sheetweb spider populations in winter wheat (Triticum aestivum L.) is related to the availability of non-crop habitats in the surrounding landscape at distinct spatial scales. We further investigate if the differences observed between three years of field data can be explained by weather. 


\section{Materials and methods}

Eighteen non-overlapping landscape sectors of $3 \mathrm{~km}$ radius were chosen in the study region around the city of Göttingen (Germany). They formed a gradient from structurally simple, with up to $85 \%$ arable land, to structurally complex, with high percentages of grassland and other non-crop habitats. Landscapes with high and low percentages of non-crop were geographically interspersed. Fields of conventionally managed winter wheat were chosen in the centre of each landscape. Due to crop rotation, the majority of sample fields had to shift each year up to $600 \mathrm{~m}$ away from the original position. The percentage of non-crop habitats comprising all land-use types except annual arable crops was calculated for eleven radii between 95 and $3000 \mathrm{~m}$ around these fields, the considered area doubling with each subsequent radius $(95,135$, $190,265,375,530,750,1060,1500,2120$ and $3000 \mathrm{~m})$. Land use data were handmapped and analysed with a Geographic Information System (ARCView 3.1, ESRI Geoinformatik GmbH, Hannover, Germany). Abundances of sheet webs were recorded in May and June with a distance method (Toft, Vangsgaard \& Goldschmidt 1995). In 2001, two measures of the fifth-closest web to random points were taken in one field per landscape during three sampling periods. In eight landscapes, an additional close-by field was sampled and the data averaged. In 2002 and 2003, five measures of the fifthclosest web were taken in one field per landscape during two sampling periods. When there were less than five webs within a radius of $30 \mathrm{~cm}$ around the random point, the number of webs found was divided by the area searched $\left(0.28 \mathrm{~m}^{2}\right)$. All measures of web abundance were taken 15 to $30 \mathrm{~m}$ from the field edge, and $10 \mathrm{~m}$ from each other. Sheetweb spiders do not eat and renew their webs daily like orbweavers, but use the same web for several days and eventually leave it (Janetos 1982). However, abandoned sheet webs degenerate quickly, and only a small fraction of the populations are floaters (Toft et al. 1995). Therefore, the abundance of webs measured in this study can be assumed to approximate the total abundance of the sheetweb spiders Bathyphantes gracilis (Blackwall, 1841), Meioneta rurestris (C.L. Koch, 1836) and Tenuiphantes tenuis (Blackwall, 1852) in the habitat. Webs of Microlinyphia (Gerhardt, 1928) and money spiders (Araneida: Erigoninae) are separable and were not considered in this study. Pearson's correlations were made between web abundance and the percentage of non-crop habitats with the $\mathrm{n} \leq 18$ landscapes as replicates using STATISTICA 6.1 (StatSoft Inc., Tulsa, OK, USA). Arithmetic means \pm standard deviations are given in text and table. We did not apply Bonferroni corrections in order to avoid inflated 
probabilities for type-II errors. This was justified given the robustness of our results across spatial scales, and because clearly more outcomes fell below the nominal $\alpha$ level of 0.05 than could have been expected by chance (Moran 2003). Weather data for Göttingen supplied by the Deutscher Wetterdienst (Offenbach, Germany) were analysed to explain between-year differences. The aeronautic index after Vugts and van Wingerenden (1976) was calculated by dividing the daily range of temperature (in ${ }^{\circ} \mathrm{C}$ ) by the mean wind velocity (in $\mathrm{m} / \mathrm{s}$ ). The number of favourable ballooning days per month was assessed by counting the days with an aeronautic index $>4$. As further possible indicators of favourable ballooning conditions we calculated the monthly mean temperature, total precipitation, and mean aeronautic index for April, May and June of the three study years.

\section{Results}

The studied landscapes were dominated by open farmland, with on average $53.8 \%$ annual arable crops, $12.5 \%$ grasslands, and 3.6\% fallows (Table 1). Forests, groves and hedgerows covered another 15.6\%. Settlements and traffic routes, including accompanying green spaces, together made up $12.8 \%$ of the area. Of the annual crops, $67.3 \%$ were cereals, which were almost entirely winter-sown.

Table 1: Average composition of the 18 studied landscape sectors $(\mathrm{r}=1500 \mathrm{~m})$.

\begin{tabular}{lrccc}
\hline Habitat type & Area $(\%) \pm$ SD & Minimum & Maximum \\
\hline Annual arable crops & 53.8 & \pm 17.4 & 25.5 & 85.0 \\
Fallows & 3.6 & \pm 2.7 & 0.6 & 10.0 \\
Grasslands & 12.5 & \pm 6.7 & 1.2 & 28.4 \\
Orchards & 0.6 & \pm 1.0 & 0.0 & 4.7 \\
Forests, groves and hedgerows & 15.6 & \pm 11.2 & 0.2 & 35.8 \\
Watercourses & 0.6 & \pm 0.8 & 0.0 & 3.6 \\
Settlements (incl. parks and gardens) & 6.5 & \pm 3.2 & 0.7 & 15.9 \\
Traffic routes (incl. fringes) & $6.1 \pm 2.0$ & 0.0 & 10.0 \\
\hline
\end{tabular}

There were significant correlations between sheetweb abundance and the percentage of non-crop habitats during four out of seven sampling periods (Fig. 1). These correlations were all positive, and robust across scales (landscape radii) from 1060 to $3000 \mathrm{~m}$ around the study plots. Towards small scales, the relationships between web abundance and landscape invariably disappeared. In mid May 2001 there were $36 \pm 23$ sheetwebs per square metre, and their abundance was positively correlated to the percentage non-crop, 
explaining $31 \%$ of the variance at a scale of $r=1500 \mathrm{~m}$ (Fig. $1 \mathrm{~A}, \mathrm{H})$. Two weeks later, in late May, the mean sheetweb abundance had doubled to $74 \pm 42$ webs per square metre. The percentage of non-crop explained $61 \%$ of the variance in sheetweb density, which rose seven-fold from 18 to 130 webs per square metre with increasing percentage of non-crop (Fig. 1 B, I). By the end of June in the same year, there were on average $131 \pm 48$ sheetwebs per square metre, and their abundance was no longer significantly related to the landscape context (Fig. 1 C, J). In 2002, sheetweb abundances stayed lower than in the preceding year (mid May: $13 \pm 15 \mathrm{~m}^{-2}$, mid June: $16 \pm 9 \mathrm{~m}^{-2}$ ). There were no significant correlations between web abundance and landscape context during either of the sampling periods (Fig. 1 D, E, K, L). Sheetweb densities were again low in early May $2003\left(4.8 \pm 4.0 \mathrm{~m}^{-2}\right)$, but significantly correlated to the percentage of noncrop habitat, which explained $55 \%$ of their variance at a scale of $r=1500 \mathrm{~m}$ (Fig. $1 \mathrm{~F}, \mathrm{M}$ ). At the end of the month, $22 \pm 11$ sheetwebs per square metre were still positively correlated to the percentage of non-crop areas, rising from $12 \mathrm{~m}^{-2}$ to $31 \mathrm{~m}^{-2}$ along the landscape gradient (Fig. $1 \mathrm{G}, \mathrm{N}$ ).

In summary, the year 2002 differed from 2001 and 2003 in that there were no significant landscape effects on sheetweb abundance, and in that the sheetweb densities did not distinctly increase across the consecutive sampling periods. This peculiarity of 2002 does not coincide with a clear pattern in mean temperatures, which were similar in all study years during May, and higher in each consecutive year during April (Table 2). The number of days with high aeronautic indices during May was equally similar between the three study years, and the pattern in April $(2003>2002>2001)$ does not match the differences in spider dynamics. However, May 2002 had exceptionally high precipitation, and the average aeronautic index was lower than in both 2001 and 2003. 

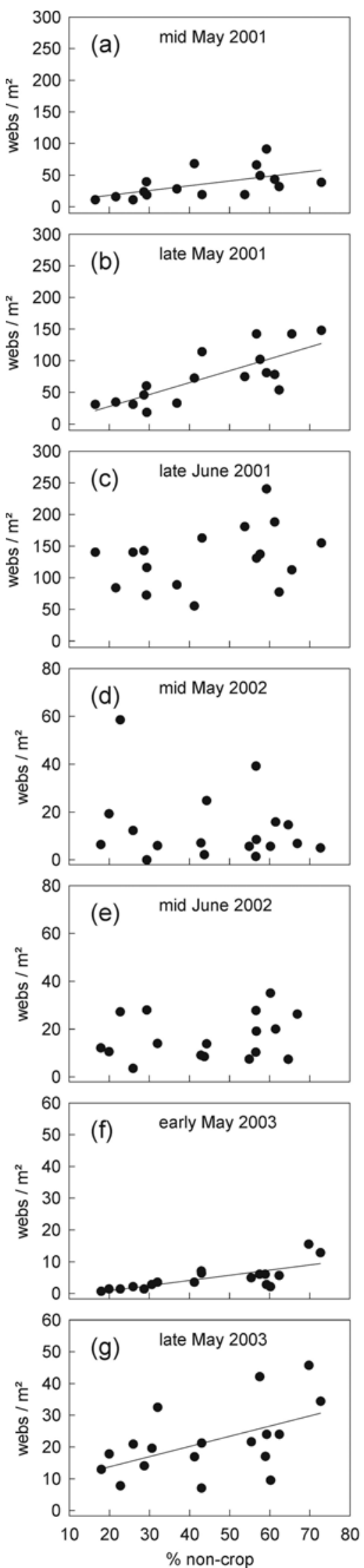

Figure 1: Correlations between the percentage of non-crop habitats and the abundance of sheetwebs. Adjoining diagrams refer to the same sampling period. A-G: Scatter plots of sheetweb abundance versus percent non-crop in landscape sectors with $1500 \mathrm{~m}$ radius around the sampling site. $\mathrm{H}-\mathrm{N}$ : Strength of the correlations (correlation coefficient $r$ ) between sheetweb abundance and percentage non-crop plotted for each radius of the landscape sectors. Filled triangles: correlation significant at $\mathrm{p}<0.05$. Open triangles: correlation not significant. Sampling periods: A, H: May $09-14^{\text {th }} 2001$; B, I: May 23-26 ${ }^{\text {th }}$ 2001; C, J: June $29^{\text {th }}-$ July $3^{\text {rd }}$ 2001; D, K: May $15-22^{\text {nd }} 2002$; E, L: June $14-18^{\text {th }} 2002 ; \mathrm{F}, \mathrm{M}$ : May $08^{\text {th }} 2003 ; \mathrm{G}, \mathrm{N}$ : May $30^{\text {th }}$ 2003. A: $\mathrm{n}=16$ landscapes, $\mathrm{r}=$ $0.56, p=0.024, y=3.1+$ $0.75 x . \mathrm{B}: \mathrm{n}=17$ landscapes, $\mathrm{r}=$ $0.78, \quad \mathrm{p}=0.0002, \mathrm{y}=-10+$ 1.88x. C: $\mathrm{n}=17$ landscapes, $\mathrm{r}=$ $0.34, \mathrm{p}=0.18$. $\mathrm{D}: \mathrm{n}=18$ landscapes, $\mathrm{r}=-0.23, \mathrm{p}=0.36$. $\mathrm{E}: \mathrm{n}=17$ landscapes, $\mathrm{r}=0.21$, $\mathrm{p}=0.42 . \mathrm{F}: \mathrm{n}=18$ landscapes, $\mathrm{r}=0.74, \mathrm{p}=0.0005, \mathrm{y}=-2.4+$ $0.16 \mathrm{x}$. G: $\mathrm{n}=18$ landscapes, $\mathrm{r}$ $=0.52, \mathrm{p}=0.026, \mathrm{y}=7.4+$ $0.32 \mathrm{x}$. 
Table 2: Weather characteristics during spring of the three study years. $T_{\text {mean }}$ : averages of the daily mean air temperature in ${ }^{\circ} \mathrm{C}$. Precipitation: monthly sum of precipitation in $\mathrm{mm}$. $\mathrm{A}_{\text {mean }}$ : averages of the daily aeronautic index (daily temperature range in ${ }^{\circ} \mathrm{C}$ divided by mean wind velocity in $\mathrm{m} / \mathrm{s}$ ). Days with $\mathrm{A}>4$ : the number of days per month with an aeronoutic index higher than four.

\begin{tabular}{|c|c|c|c|c|}
\hline & & 2001 & 2002 & 2003 \\
\hline \multirow{3}{*}{$\mathrm{T}_{\text {mean }}$} & April & 7.4 & 7.8 & 8.5 \\
\hline & May & 13.6 & 13.6 & 13.9 \\
\hline & June & 13.9 & 16.7 & 18.1 \\
\hline \multirow{3}{*}{ precipitation } & April & 61 & 61 & 35 \\
\hline & May & 23 & 111 & 55 \\
\hline & June & 60 & 71 & 48 \\
\hline \multirow{3}{*}{$\mathrm{A}_{\text {mean }}$} & April & 3.3 & 4.6 & 4.3 \\
\hline & May & 5.4 & 4.2 & 5.0 \\
\hline & June & 5.4 & 5.1 & 7.0 \\
\hline \multirow{3}{*}{$\begin{array}{l}\text { days } \\
A>4\end{array}$} & April & 7 & 13 & 15 \\
\hline & May & 17 & 17 & 16 \\
\hline & June & 18 & 14 & 22 \\
\hline
\end{tabular}

\section{Discussion}

According to our results, sheetweb spider abundances in arable crops are influenced to a great extent by the composition of the surrounding landscape. In 2001 and 2003, spider abundances multiplied within weeks during spring and were thereby several times higher in landscapes with high percentages of non-crop habitats than in purely cropdominated landscapes. However, spider densities appeared unaffected by the landscape context in 2002 and stayed comparatively low throughout May. Positive effects of noncrop habitats on sheetweb spider densities have long been predicted (Luczak 1979; Bishop \& Riechert 1990; Topping \& Sunderland 1994; Toft 1995; Halley et al. 1996), but are difficult to show because of the large-scale aerial dispersal of these species. The ground-based immigration of other spiders such as Oedothorax apicatus (Erigoninae) and wolf spiders (Lycosidae) can be detected tens of metres adjacent to field margins in which they overwinter (e.g. Holland, Perry \& Winder 1999; Lemke \& Poehling 2002). In contrast, the correlations between sheetweb spider abundance and percentage noncrop were most distinct at scales of one to three kilometres, indicating that the spiders move over such large distances in numbers relevant for the build-up of crop field populations. The high mobility may also explain why sheetweb spiders are more evenly distributed across fields than other arthropods (Holland et al. 1999). The significant landscape effects during the two sampling periods in May 2001 had disappeared by late June, with abundances exceeding one hundred webs per square metre even in some of the most crop-dominated landscapes. This was presumably caused by two complementary processes. First, ongoing dispersal could have levelled out the 
differences between landscapes. Second, many spiders have reproduced by that time (Topping \& Sunderland 1994; Thorbek, Sunderland \& Topping 2003), approaching their maximum densities which can be constrained by local factors such as the availability of sites for web construction (Alderweireldt 1994).

The constantly low web abundances and the absence of landscape effects in 2002 suggest that little aerial immigration into the fields took place prior to the sampling periods. This is in strong contrast with the two other years, which underlines the value of long-term studies of processes depending on uncontrollable forces such as weather. The three years of the present study do not allow a formal discrimination between the potential factors that inhibited immigration of sheetweb spiders into fields in 2002. It is nevertheless noteworthy that the number of days with an aeronautic index higher than four, which reliably predicted high ballooning activity in the coastal study of Vugts and van Wingerenden (1976), did not indicate a reduced number of favourable ballooning days during April or May 2002 relative to the other years. The mean aeronautic index was somewhat lower in May 2002, but the strongest contrast between the three years lay in the exceptionally high $111 \mathrm{~mm}$ of rainfall during May 2002, with half of that amount in 2003 and one fourth of it in 2001. Wet weather has delayed the date of first haymaking from about mid May to late May/early June in 2002, a factor that could induce sheetweb spiders to emigrate from grasslands into crops (Thomas \& Jepson 1997). Other potential factors of ballooning motivation and/or preconditions could have also been affected by rain. Further inland studies of spider ballooning are needed to reveal if factors additional to wind velocities determine the aerial activity of spiders.

In conclusion, populations of sheetweb spiders, a dominant group of predators in temperate farmland, were enhanced by high percentages of non-crop habitats in the surrounding landscape. The response to the landscape context on scales of one to three kilometres underpins their high dispersal ability, and the need for a large-scale perspective to understand their population dynamics. Sheetweb spiders contribute to the natural control of major crop pests such as cereal aphids (Symondson, Sunderland \& Greenstone 2002; Östman, Ekbom \& Bengtsson 2003; Schmidt et al. 2003). The earlyseason landscape effects on spiders can be particularly important for aphid suppression, because predation is expected to have the highest impact during the initially low aphid densities (Luczak 1979; Carter et al. 1982; Chiverton 1986). Our study further indicates that parts of the strong inter-annual variability typical for farmland arthropods can be 
explained by weather. A better understanding of landscape and climate effects on natural enemies may improve pest management by predicting situations favourable for potential biocontrol. Semi-natural non-crop habitats such as fallows and grasslands should be preserved on a landscape scale, to enhance pest control by their natural enemies and augment overall farmland biodiversity.

\section{Acknowledgements}

We are indebted to Søren Toft and Jason Tylinanakis for valuable comments on the manuscript, and to Doreen Gabriel, Anne le Mellec and Christoph Bürger for help with the landscape data. MHS was supported by the German National Academic Foundation (Studienstiftung des deutschen Volkes). 


\section{Relative importance of predators and parasitoids for cereal aphid control}

\section{Summary}

Field experiments with manipulations of natural enemies of plant-feeding insects may show how a diverse enemy group ensures an important ecosystem function such as naturally occurring biological pest control. We studied cereal aphid populations in winter wheat under experimentally reduced densities of: (i) ground-dwelling generalist predators (mostly spiders, carabid and staphylinid beetles); (ii) flying predators (coccinellid beetles, syrphid flies, gall midges, etc.) and parasitoids (aphidiid wasps), and the combination of (i) and (ii), compared to open controls. Aphid populations were $18 \%$ higher at reduced densities of ground-dwelling predators, $70 \%$ higher when flying predators and parasitoids were removed, and 172\% higher in the removal of both enemy groups. Parasitoid wasps probably had the strongest effect, as flying predators occurred only in negligible densities. The great importance of parasitism is a new finding for aphid control in cereal fields. In conclusion, more detailed knowledge of the mechanisms of natural pest control would help to develop environmentally sound crop management with reduced pesticide applications.

Keywords: biological control, Aphidiidae, Araneae, Sitobion avenae, winter wheat

\section{Introduction}

Top-down regulation of herbivores is more likely in ecosystems with few species and little heterogeneity in space and time, as suggested by models and recent meta-analysis of field studies (Hawkins et al. 1999; Schmitz et al. 2000). Despite their temporal instability, annual crops are terrestrial habitats in which predators can exert the strongest regulation of herbivore populations, and where herbivores may cause the highest levels of plant damage when predators fail to control them (Halaj \& Wise 2001). Yet herbivore-natural enemy interactions in winter wheat, which is the dominant crop in many temperate areas, are still not sufficiently understood to predict pest outbreaks. The lack of knowledge of the relative importance of control agents and their interactions contributes to this unpredictability (Sunderland et al. 1997; Fagan et al. 1998; Lang 2003). 
The herbivore community of winter wheat in Germany is dominated by three species of cereal aphids (Sitobion avenae (Fabricius), Metopolophium dirhodum (Walker), Rhopalosiphum padi (Linnaeus)), which cause economic damage in some years, and against which insecticides are commonly applied. Several groups of natural enemies may limit aphid populations: adults and larvae of ladybirds (Coccinellidae), larvae of hoverflies (Syrphidae), gall midge larvae (Cecidomyiidae) and lacewing larvae (Chrysopidae) live in the upper vegetation of cereal fields and feed predominantly on aphids (Wratten \& Powell 1991). Parasitoid wasps (Hymenoptera: mainly Aphidiidae) occupy the same stratum and are specialised on one or several aphid host species (Sigsgaard 2002). Ground-dwelling predators like spiders (Araneae), carabids (Carabidae) and rove beetles (Staphylinidae) have a much wider prey spectrum, but include aphids in their diet and are able to suppress their numbers (Symondson et al. 2002). The relative abundances of the natural enemies vary widely among years and study sites. There are published records of successful aphid control by all of them, but their relative importance and interactions are little known, because most field studies deal with only one group. Thus it is necessary to experimentally study the effect of several enemy groups at the same time (Winder et al. 1994; Sih et al. 1998, Lang 2003).

Here, we compared the relative impact of different natural enemies on aphid population development in a two-factor field experiment. The predation effect under natural densities was compared with treatments where either ground-dwelling predators or flying predators and parasitoids were reduced singly and in combination. We expected that these two groups have an effect on aphid population growth, and that the generalist predators were most important early in the season, while specialist predators and parasitoids, which respond numerically to aphid abundances, would have their highest impact at high aphid densities late in the season (Kromp 1999; Marc et al. 1999).

\section{Materials and methods}

The experiments were carried out in 2001 in four insecticide-free winter wheat fields, representing varied site conditions typical for the area. The field cultivation was done by the Reinshof research farm of Göttingen University in Lower Saxony, Germany. Two of the fields were situated in a structurally rich landscape with nutrient poor calcareous soils and a high diversity of land-use types. The other two fields lay in a structurally poor, crop-field dominated landscape in the Leine valley on deep, nutrient rich loamy soils. In each landscape, one field was conventionally managed (structurally 
poor landscape: Field 2; structurally rich landscape: Field 4), and one was managed according to the European Union Regulation 2092/91/EEC on organic farming, without artificial fertilizers and pesticides (structurally poor landscape: Field 1; structurally rich landscape: Field 3). The experimental treatments were applied in a $2 \times 2$ factorial design with six replications of ground-dwelling predator removal (-G), flying predator + parasitoid removal (-F), complete removal (the combination of both; -G-F) and open control (0) in each field. Experimental plots were circular with a diameter of one meter, resulting in a plot area of $0.78 \mathrm{~m}^{2}$. For the removal of ground-dwelling predators, plastic barriers reaching $10 \mathrm{~cm}$ into the soil and projecting $30 \mathrm{~cm}$ over the surface were set up in early May to reduce the exchange with the surrounding field. One "live" pitfall trap with a circular opening of $8.7 \mathrm{~cm}$ diameter was placed in each barrier, and operated on thirteen days throughout May and June. Ground-dwelling predators (spiders, carabids, rove beetles and ants) captured in these live traps were identified and removed. All other animals were returned into the experimental plot. Additionally, web-building spiders were removed manually six times during May and June. The webs were made visible with starch powder (Toft et al. 1995), spiders individually removed with a pooter, identified and released outside the plot. To test for the effectiveness of the web spider removal, spider webs were counted in all treatments in Field 1 on July 17th, one day after the cages had been removed and aphids been counted. Flying aphid predators and parasitoids were reduced by setting wire cages over the plots at the end of June. The cages had a mesh size of $8 \mathrm{~mm}$ to avoid changes in microclimate and were covered with sticky glue to deter or capture flying arthropods (see Müller \& Godfray 1999). The bottom line of the cages was left without glue, and gaps resulting from the uneven soil surface gave ground-dwelling predators access. To test whether the cages had a relevant effect on the microclimate, daily minimum and maximum temperature $(\mathrm{T})$ and relative humidity $(\mathrm{h})$ were measured on ten consecutive days within and outside a wire cage. $\mathrm{t}$ tests for matched pairs yielded no detectable differences (synchronous samples as pairs; $\operatorname{Tmin}=11.64 \pm 0.66$ versus $11.74 \pm 0.63{ }^{\circ} \mathrm{C}, \mathrm{t}=-1.58$, d.f. $=9, \mathrm{p}=0.148 ; \operatorname{Tmax}=$ $28.01 \pm 1.71$ versus $28.80 \pm 1.65^{\circ} \mathrm{C}, \mathrm{t}=-1.22$, d.f. $=9, \mathrm{p}=0.254 ; \mathrm{hmin}=63.0 \pm 3.9$ versus $61.2 \pm 5.0 \%, \mathrm{t}=0.41$, d.f. $=9, \mathrm{p}=0.689 ; \mathrm{hmax}=100.0 \pm 0 \%$ in both cases).

Aphids and all natural enemies were counted visually in all treatments on 20 (first date, wheat flowering, 21-26 June 2001) and 40 (second date, milk ripening, 14-18 July 2001) wheat shoots per plot, respectively, before the installation of the wire cages, and three weeks later, after the cages had been removed. Parasitized aphids (mummies) 
were taken to the lab, to rear and identify the parasitoids. Parasitism was calculated as the ratio of mummies to total aphids. Counts of aphids were converted into individuals per 100 shoots. Aphid densities were analysed by ANOVA, including the factors field (1-4), ground-dwelling predator removal (1-2 = yes-no) and flying predator plus parasitoid removal $(1-2=$ yes-no). The skewness of the data was compensated either by $\log 10(x+1)$-transformation of the aphid densities or arcsine-transformation of aphid parasitism. In addition, the relation of aphid population growth (difference between the two counting dates) to percent parasitism was analysed by simple regressions. All statistical treatments were performed using the STATISTICA for Windows Package 5.5 (StatSoft Inc., Tulsa, USA).

\section{Results}

Overall, we found 4715 aphids, of which $89.7 \%$ were Sitobion avenae, followed by Metopolophium dirhodum (7.9\%), and Rhopalosiphum padi (2.4\%). Aphid infestations averaged 73.6 individuals per 100 shoots, well below the threshold level of economic damage (5 per shoot; Giller et al. 1995). The open-field population densities for aphids and their natural enemies are summarised in Table 1. Aphid-eating gall midges (Cecidomyiidae, Aphidoletes cf. aphidimyza (Rondani)) were only abundant in field 1 with $31.0 \pm 4.7$ individuals per 100 shoots, without significant differences between treatments. In the other three fields, these gall midges occurred only with $0.5 \pm 0.2$ individuals per 100 shoots. Spiders were the next most numerous predator on the vegetation, with on average $5.3 \pm 0.5$ individuals per 100 shoots. Larvae of lacewings (Chrysopidae; $0.14 \pm 0.09$ individuals per 100 shoots) and ladybirds (Coccinellidae; $0.04 \pm 0.04$ individuals per 100 shoots) were rare, and aphid-eating larvae of hoverflies (Syrphidae) were not encountered at all. 
Table 1: Ambient (unmanipulated) densities of aphids and their natural enemies in the experimental fields. Aphids, parasitoids and flying predators: Individuals per 100 shoots, $n=24$ plots (treatment 0 ). Web spiders: Individuals per square meter, $\mathrm{n}=48$ plots $(17 \mathrm{May}$; treatments $-\mathrm{G}$ and $-\mathrm{G}-\mathrm{F}$ before manipulation) and $n=12$ plots (17 July; treatment 0 and $-F$; Field 1 only). Other ground-dwelling predators: Individuals captured per unenclosed pitfall trap on 13 days through May-June, n $=24$ traps $(6$ per field). Arithmetic means \pm standard errors.

\begin{tabular}{|c|c|c|c|}
\hline & & 21-26 June & 14-18 July \\
\hline \multirow[t]{3}{*}{ Aphids } & Sitobion avenae & $39.2 \pm 11.7$ & $59.2 \pm 5.7$ \\
\hline & Metopolophium dirhodum & $16.9 \pm 4.4$ & $0.4 \pm 0.2$ \\
\hline & Rhopalosiphum padi & $1.7 \pm 1.3$ & $0.1 \pm 0.1$ \\
\hline Parasitoids & Aphidiidae $^{\mathrm{a}}$ & $0.8 \pm 0.8$ & $15.6 \pm 2.6$ \\
\hline \multirow[t]{5}{*}{ Flying predators } & Aphidoletes cf. aphidimyza (larvae) & $10.4 \pm 4.8$ & $13.1 \pm 5.4$ \\
\hline & Araneae $^{\mathrm{b}}$ & $4.6 \pm 1.4$ & $6.8 \pm 0.8$ \\
\hline & Chrysopidae (larvae) & 0 & $0.1 \pm 0.1$ \\
\hline & Coccinellidae (larvae) & 0 & 0 \\
\hline & & 17 May & 17 July \\
\hline \multirow{5}{*}{$\begin{array}{l}\text { Ground-dwelling } \\
\text { predators }\end{array}$} & web spiders $^{\mathrm{c}}$ & $10.9 \pm 0.9$ & $95.6 \pm 9.2$ \\
\hline & & May-June & \\
\hline & cursorial spiders $^{\mathrm{d}}$ & $20.5 \pm 2.0$ & \\
\hline & Carabidae & $22.1 \pm 1.8$ & \\
\hline & Staphylinidae & $8.2 \pm 1.5$ & \\
\hline
\end{tabular}

a Aphid mummies: mostly Aphidius, hyperparasitized by Asaphes (Pteromalidae) and Dendrocerus (Megaspilidae)

${ }^{\mathrm{b}}$ Individuals associated with shoots: mostly Linyphiidae and Theridiidae

${ }^{\mathrm{c}}$ Mostly Tenuiphantes tenuis (Linyphiidae) and Bathyphantes gracilis (Linyphiidae)

${ }^{\mathrm{d}}$ Pardosa sp. (Lycosidae) and Pachygnatha degeeri (Tetragnathidae)

With pitfall traps, 603 carabids, 393 rove beetles, 10 ants (Formicidae) and 580 spiders (309 Lycosidae, 238 Linyphiidae and 33 Tetragnathidae) were removed from treatments $-\mathrm{G}$ and $-\mathrm{G}-\mathrm{F}$ at 13 dates during May and June. Another 2439 spiders were removed manually at 6 dates through web search. These were dominated by the subfamily Linyphiinae (80.6\%), followed by Araneidae plus Tetragnathidae (11.3\%), Erigoninae (5.3\%), and Theridiidae (2.7\%). The initial density of spider webs on May 17 th was $10.9 \pm 0.9 \mathrm{~m}^{-2}$, without significant differences between fields. On July $17 \mathrm{th}$, at the end of the experiment, web abundance in field 1 was $41.2 \%$ lower in the ground predator removal $\left(\mathrm{F}_{1,20}=18.7, \mathrm{p}<0.001\right)$, and unaffected by the flying predator removal $\left(\mathrm{F}_{1,20}=\right.$ $0.27, \mathrm{p}=0.61)$. In the un-manipulated plots $95.6 \pm 9.2$ webs per square meter covered some $10.6 \pm 1.3 \%$ of the ground surface.

Aphid densities at wheat flowering showed no significant treatment effects $\left(-G\right.$ : $F_{1,80}=$ $\left.0.46, p=0.50 ;-F: F_{1,80}=1.56, p=0.21\right)$. They differed between fields $\left(F_{3,80}=7.65, p=\right.$ 
0.0001 ), ranging from $30.8 \pm 9.1$ individuals per 100 shoots in field 3 to $71.9 \pm 8.5$ individuals per 100 shoots in field 4. By the end of the experiment (milk ripening stage), the removal of ground-dwelling predators led to a $44.4 \%$ increase in aphid populations $\left(\mathrm{F}_{1,80}=4.0, \mathrm{p}=0.048\right)$, while the removal of flying predators led to an increase in aphid densities of $102.8 \%\left(\mathrm{~F}_{1,80}=38.2, \mathrm{p}<0.0001\right)$. Aphid densities were 17.9\%, 69.8\% and $172.0 \%$ higher in the treatments $-\mathrm{G},-\mathrm{F}$ and $-\mathrm{G}-\mathrm{F}$ respectively, compared to open controls (figure 1). There was no significant interaction between the removal treatments $\left(-\mathrm{G} \times-\mathrm{F}: \mathrm{F}_{1,80}=2.0, \mathrm{p}=0.16\right)$. The effect of ground-dwelling predators varied between fields, being marked only in fields 1 and 4 (interaction $-\mathrm{G} \times$ field: $\mathrm{F}_{3,80}=2.8, \mathrm{p}=$ $0.048)$.

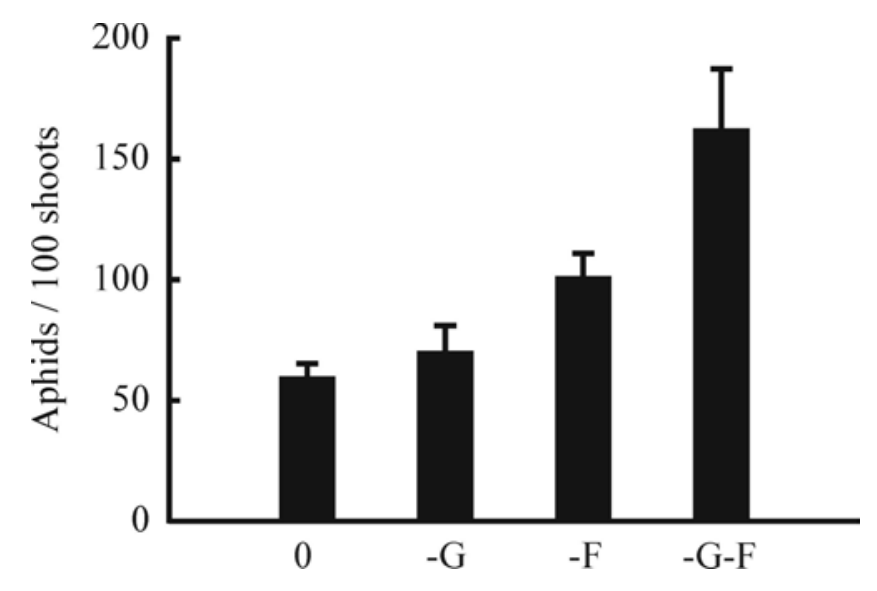

Figure 1: Aphid densities at the end of the experiment (milk ripening). 0, open control; -G, grounddwelling predator removal; -F, flying predator and parasitoid removal; -G-F, removal of all predators and parasitoids.

Parasitism of aphids by wasps (Aphidiidae) increased from $1.8 \pm 1.1 \%$ on the first sampling date to $18.4 \pm 1.5 \%$ on the second date (for absolute densities, see Table 1). On the second date, parasitism differed significantly between fields $\left(\mathrm{F}_{3,80}=13.8, \mathrm{p}<\right.$ $0.001)$, with higher values in the structurally rich landscape $(24.5 \pm 2.3$ versus $12.4 \pm$ $1.6 \%$ ), but no obvious differences between organic and conventional management (18.5 \pm 2.4 versus $18.3 \pm 1.9 \%$ ). Parasitism was $56.4 \%$ lower in the flying predator and parasitoid removal treatment than in controls $\left(11.2 \pm 1.3\right.$ versus $25.6 \pm 2.2 \% ; \mathrm{F}_{1,80}=$ $40.85, \mathrm{p}<0.001$ ), and tended also to be reduced by ground-dwelling predator removal $\left(16.0 \pm 2.0\right.$ versus $\left.20.8 \pm 2.2 \% ; \mathrm{F}_{1,80}=3.18, \mathrm{p}=0.078\right)$. The development of aphid populations correlated negatively with parasitism (figure 2), but not with predator densities. Aphid populations decreased between wheat flowering and milk ripening at 
parasitism rates higher than $33 \%$. The negative correlation between aphid population growth and parasitism was present in every field, and hence was not an artefact of fieldspecific differences (field 1: $\mathrm{r}=-0.51, \mathrm{n}=24$ plots, $\mathrm{p}=0.01, \mathrm{y}=193-6.9 \mathrm{x}$; field 2: $\mathrm{r}=$ $-0.47, \mathrm{n}=24$ plots, $\mathrm{p}=0.02, \mathrm{y}=93-2.4 \mathrm{x}$; field $3: \mathrm{r}=-0.58, \mathrm{n}=24$ plots, $\mathrm{p}=0.003, \mathrm{y}=$ 167 - 3.2x; field 4: $\mathrm{r}=-0.74, \mathrm{n}=24$ plots, $\mathrm{p}<0.001, \mathrm{y}=223-6.6 \mathrm{x})$. Sixty-eight percent of the aphid mummies reared in the laboratory contained hyperparasitoids.

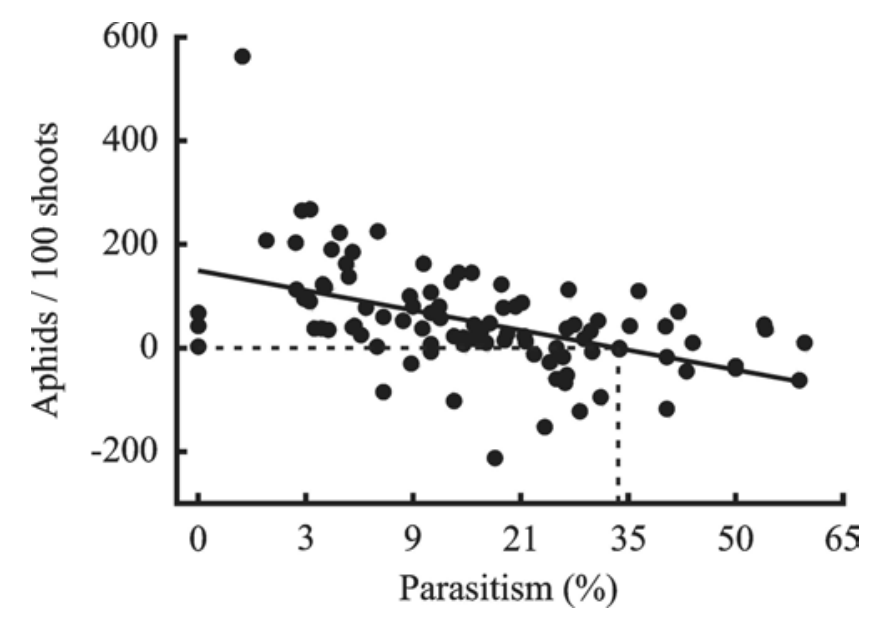

Figure 2: Correlation between aphid population growth (the difference in aphid density between wheat flowering and milk ripening) and (arcsine-transformed) parasitism. $\mathrm{r}=-0.49, \mathrm{n}=96$ plots, $\mathrm{p}<0.001 . \mathrm{y}=$ $149-3.8 x$.

\section{Discussion}

The experimental manipulations showed that both groups of enemies are able to reduce cereal aphid population growth. The effect of flying predators plus parasitoids was stronger than that of the ground-dwelling predators. As the abundance of flying predators was very low, parasitoid wasps were likely to have provided the most important contribution towards suppression of aphid densities in the treatments in which they occurred at natural densities. The reduced parasitism in the patches where the flying predators and parasitoids were removed, and the overall negative correlation between aphid population growth and parasitism support this finding. At parasitism levels above $33 \%$, aphid densities decreased between the two sampling dates. This rate is within the threshold value of 32 to $36 \%$, below which success in classical biological control has never been found (Hawkins \& Cornell 1994). Few other studies report similarly high parasitism of cereal aphids (e.g. Sigsgaard 2002), and only Levie et al. (2000) found regulation of cereal aphids by parasitoids released into field cages. To the 
best of the authors' knowledge, the study presented here is the first field experiment that gives evidence for a control of cereal aphids by naturally occurring parasitoid wasps. Fluctuations in population density, abiotic stress factors, hyperparasitism, and intraguild predation of parasitoids by predators may prevent the effectiveness of parasitoids in many situations (Sunderland et al. 1997). The high levels of hyperparasitism that we found did not appear to prevent an effective control of cereal aphids by their primary parasitoids during the time period examined, although hyperparasitism has been shown previously to reduce the effectiveness of primary parasitoids (Rosenheim 1998).

Many studies show that ground-dwelling generalist predators may reduce pest numbers (Symondson et al. 2002), but several in European winter wheat revealed only weak, temporary or no effects (Holland et al. 1996; Holland \& Thomas 1997; Lang 2003). Theoretical considerations and some experimental evidence suggest that effects of ground-dwelling predators on aphids should be strongest as early as May, when aphid densities in cereals are low and reproduction is slower than in summer (Chiverton 1986; Kromp 1999; Marc et al. 1999; Lang 2003). Our study revealed an effect of grounddwelling predators in July, which may be attributable to the fact that mostly linyphiid spiders were manipulated. Their abundance peaks in July, when the densities of other ground-dwelling predators have already declined.

Multiple enemy species may act synergistically on their shared prey (Völkl 1992; Hoelmer et al. 1994; Losey \& Denno 1998; Colfer \& Rosenheim 2001). In contrast, intraguild predation, and particularly predation of parasitized pests may disrupt biological control (Rosenheim et al. 1995; Sunderland et al. 1997; Raymond et al. 2000). Our results indicate that the dominant web spiders and parasitoid wasps complement each other. Removal of ground-dwelling predators tended to reduce parasitism, hence strong intraguild predation appears unlikely. Aphids get caught in linyphiid webs when they drop from the vegetation, a behaviour also shown to escape from Aphidius wasps (Longley \& Jepson 1996). The immobility of aphid mummies should preserve them from spider predation. This may explain why the generalist predators in our study did not interfere with parasitoids. In contrast, vegetation-climbing carabids may prefer mummies to unparasitized aphids and thereby disrupt biological control by parasitoid wasps (Snyder \& Ives 2001).

Entomophagous arthropods are expected to benefit from diversification within the field and at the landscape level (due to diverse food sources, places for hibernation, and 
shelter from the disturbances caused by agricultural practices; Altieri et al. 1993; Wratten \& van Emden 1995; Thies \& Tscharntke 1999; Sunderland \& Samu 2000). In accordance with this hypothesis, we found higher parasitism in the structurally rich landscape, but unexpectedly no differences between conventional and organic management. However, more landscape and management replicates are necessary to verify these relations.

In conclusion, the role of parasitoid wasps in the control of cereal aphids has to be reconsidered. They appeared to be more important than ground-dwelling generalist predators, and the effects of both groups were complementary. More field experiments should compare the relative impacts of different aphid natural enemies under the varied relative abundances at which they occur in the field. Also, more knowledge is needed about factors that determine their population densities, including landscape, climate, and management. Biological pest control becomes increasingly important, as public opinion is in favour of reduced pesticide applications and environmentally sound cereal production (Tilman et al. 2002). Farming schemes could further promote, and benefit from, naturally occurring aphid enemies.

\section{Acknowledgements}

The authors are grateful to Jay Rosenheim, Keith Sunderland, David Wise and two anonymous referees for giving valuable comments on an earlier draft of this article, and to Jason Tylianakis for linguistic advice. The study is part of the BIOPLEX project (Biodiversity and spatial complexity in agricultural landscapes under global change), funded by the BIOLOG program of the German Ministry for Research and Education (BMBF). M.H.S. was supported by the German National Academic Foundation (Studienstiftung des deutschen Volkes). 


\begin{abstract}
Large populations of natural enemies are the basis for natural pest control. Effects of mulch on predator-prey interactions in arable fields are poorly known, despite its potential to enhance ground-dwelling predators and thereby reduce pest infestations. We studied densities of predators and parasitoids and their impact on cereal aphids in the presence and absence of mulch. Released populations of the bird cherry aphid Rhopalosiphum padi (L.) (Homoptera: Aphididae), and two naturally occurring aphid species, were monitored under experimentally reduced densities of (i) ground-dwelling predators, (ii) flying predators and parasitoids, and (iii) with straw mulch. The three treatments were applied in a $2 \times 2 \times 2$ factorial design in a field of spring wheat (Triticum aestivum L.). Exclusion of ground-dwelling predators increased aphid populations by $55 \%$ in June and $40 \%$ in July, respectively. Mulched plots had $25 \%$ lower aphid densities in June. This was presumably due to enhanced densities of spiders (Araneida) in mulched plots. Exclusion of flying predators and parasitoids led to $94 \%$ higher aphid populations in late July (109 versus 56 individuals per 100 shoots), irrespective of mulch or ground predator manipulation. This was attributed to larvae of gall midges Aphidoletes cf. aphidimyza (Rondani) (Diptera: Cecidomyiidae) and hoverflies (Diptera: Syrphidae). The results indicate that scarcity of predators and a bare soil surface render crops more susceptible to arthropod pests. Farming schemes should aim at enhancing both ground-dwelling and flying predators for high levels of natural pest control.
\end{abstract}

\title{
Introduction
}

Natural control of herbivores is particularly important, and often strong, in agricultural systems (Halaj \& Wise, 2001; Symondson et al., 2002). As it is usually due to multiple enemies, their relative role and interactions need examination (Sunderland et al., 1997; Hawkins et al., 1999; Losey \& Denno, 1999; Sih et al., 1998). For example, cereal aphids attacking wheat can be suppressed by generalist predators such as spiders and ground beetles, specialist predators like ladybirds (Coleoptera: Coccinellidae) and hoverflies, and parasitoid wasps (Hymenoptera: Aphidiidae) (Wratten \& Powell, 1991). Generalist predators can already be abundant when aphids start to colonize crop fields, 
because they do not entirely depend upon aphids as prey. Their effect on aphids is often strong early in the season (Chiverton, 1986; Marc et al., 1999; Lang 2003), but can continue until aphid populations peak (Winder, 1990; Schmidt et al., 2003). In other cases, substantial reductions of ground-dwelling predator densities affected aphids only erratically (Holland et al., 1996; Holland \& Thomas, 1997). The more specialised flying predators are most effective during high aphid densities late in the season and can accelerate the breakdown of aphid populations (Chambers et al., 1983; Freier et al., 1997). Recent studies suggest that parasitoid wasps contribute more to the natural control of cereal aphids than has been previously thought (Levie et al., 2000; Schmidt et al., 2003). Still, the majority of field experiments manipulated only one group of aphid enemies at a time, and the relative role and interactions between different aphid enemies remain little explored. In a study involving different groups of ground-dwelling predators, ground beetles reduced the densities of wolf spiders, but the general effect of ground beetles and spiders on aphids was additive (Lang, 2003). Sheetweb weavers (Araneida: Linyphiidae) and parasitoid wasps may complement each other's impact on cereal aphid populations (Schmidt et al., 2003). In a similar system involving pea aphids on alfalfa, ground beetles disrupted biological control by parasitoids, while in turn other generalist predators (Nabidae and web spiders) and parasitoids acted additively (Snyder \& Ives, 2001, 2003).

Densities, and thereby pest control potential of entomophagous arthropods, are affected by stand structure, prey availability, and disturbance (Landis et al., 2000). Mulch can enhance predator populations by giving shelter (Riechert \& Bishop, 1990; Rypstra et al., 1999), by providing alternative prey from the detritivore food chain (Humphreys \& Mowat, 1994; Scheu, 2001), and by reducing intraguild predation (Finke \& Denno, 2002, 2003). Straw mulch is used in vegetable cultivation (e.g. Snyder \& Wise, 1999), and in cereals in tropical and arid environments (Amir \& Sinclair, 1996; Buerkert et al., 2000). Although mulching techniques may easily be applied, little evidence exists for effects of mulch on beneficial arthropods in temperate cereal fields (Sunderland \& Samu, 2000). Mulch could enhance the densities of generalist predators, and thereby strengthen the control of agricultural pests (Wise et al., 1999). Here, straw mulch and selective exclusion of two natural enemy groups of cereal aphids were applied in a three-factorial field experiment in spring wheat. The study aimed at testing (i) the relative importance of ground-dwelling and flying aphid enemies in spring wheat, (ii) if 
mulch alters the natural enemy community, and (iii) if mulch thereby affects cereal aphid control.

\section{Materials and methods}

The experiment was carried out in a 0.5 ha field sown with spring wheat (variety 'Thassos') in April 2001. It was treated once with the herbicide IPU 500, and fertilized with $100 \mathrm{~kg} \mathrm{~N} /$ ha. Treatments were installed in a $2 \times 2 \times 2$ factorial design comprising exclusion of ground-dwelling predators (-G), exclusion of flying predators and parasitoids (-F), and mulching (M). Four replicates of each of the eight possible treatment combinations were set up in 32 circular experimental plots of $1 \mathrm{~m}$ diameter $\left(0.79 \mathrm{~m}^{2}\right)$. Densities of ground-dwelling predators were reduced by installing plastic barriers in early May, that reached $5 \mathrm{~cm}$ into the soil and projected $25 \mathrm{~cm}$ over the surface. One pitfall trap ( $8.7 \mathrm{~cm}$ diameter) was placed in each barrier and operated on eleven days between May 29th and June 31st. Captured ground beetles and spiders were counted and released outside the plots; all other arthropods were returned into the plots. Additionally, spider webs were made visible with starch powder on five dates between May 31st and July 3rd and spiders manually removed from the plots. Web abundance was recorded in all plots at the end of the experiment, on July 24th. Flying predators and parasitoids were excluded by setting wire cages over the plots in early July, corresponding to their immigration after the establishment of aphid-populations (Chambers et al., 1983). Cages had a coarse mesh of $8 \mathrm{~mm}$ to avoid microclimatic change. They were covered with sticky glue to deter or capture flying aphid enemies, sparing the lower edge to avoid effects on ground-dwelling arthropods (Müller \& Godfray, 1999; Schmidt et al., 2003). Barley straw shredded to 10-15 cm was applied as mulch at $0.9 \mathrm{~kg}$ per plot in late May, covering some $90 \%$ of the soil surface.

500 laboratory-reared Rhopalosiphum padi were added to the centre of each plot on June 15th. This was done to reduce natural variation in aphid densities between plots, and because $R$. padi is known to be suppressed by ground-dwelling predators (Chiverton, 1986). Aphids and their natural enemies were counted visually on June 25th (first sampling date, wheat flowering) on 20 wheat shoots per plot, and on July 23rd (second sampling date, milk ripening stage) on 40 shoots per plot. Counts were converted into individuals per 100 shoots. Parasitized aphids (mummies) were taken to the laboratory, to rear and identify the parasitoids. Parasitism was calculated as the ratio of mummies to total aphids. Arthropod densities were analysed using Generalized 
Linear Models with Poisson distribution in Statistica 6.1 for Windows (StatSoft Inc., Tulsa, OK). For the first sampling date, effects of the factors mulch $(0-1=$ no-yes $)$ and ground-dwelling predator exclusion $(0-1=$ no-yes $)$ were tested. Analyses for the second date additionally included the factor flying predator plus parasitoid exclusion $(0-1=$ noyes). Untransformed arithmetic means \pm one standard error are given in text, tables and figures.

\section{Results}

In the plots without enemy manipulations, the bird cherry aphid Rhopalosiphum padi was dominant during wheat flowering (Table 1). Its densities fell below those of Sitobion avenae (Fabricius) at the milk ripening stage. Aphid mummies were predominantly found at the second date, comprising $14 \%$ of all aphids on July $23 \mathrm{rd}$. Flying predators were more common on July 23rd, as well. Most abundant were larvae of Aphidoletes cf. aphidimyza, followed by spiders and hoverfly larvae. Despite high numbers of hoverfly eggs already on June 25 th, only few larvae were encountered. Ground-dwelling predators were represented by ground beetles, wolf spiders, and sheetweb weavers.

\section{Ground-dwelling predators}

271 ground beetles and 95 spiders (37 Linyphiidae and 58 Lycosidae) were removed from treatment $-\mathrm{G}(\mathrm{n}=16$ plots $)$ with pitfall traps. $88 \%$ more spiders were captured in the mulched plots than in the plots without mulch $(7.8 \pm 1.1$ versus $4.1 \pm 0.7$ individuals, d.f. $=14, \mathrm{~W}=7.3, \mathrm{P}<0.01$ ), while ground beetles showed no significant difference $(16.3 \pm 2.8$ versus $17.6 \pm 3.2$ individuals, d.f. $=14, \mathrm{~W}=0.1, \mathrm{P}=0.75)$. Rove beetles (Coleoptera: Staphylinidae), as well as spiders other than Linyphiidae and Lycosidae were not captured. Through web search, another 152 Linyphiidae were removed from the 16 plots of treatment $-\mathrm{G}$, whereby mulched and unmulched plots showed no significant difference. On July 24 th, $55 \pm 3.7$ sheetwebs per square meter were found across all treatments. Web abundances were $16 \%$ lower in the grounddwelling predator exclusion, and $21 \%$ higher in the mulched plots, but neither the differences nor their interaction were significant (-G: d.f. $=24, \mathrm{~W}=1.5, \mathrm{P}=0.22, \mathrm{M}$ : d.f. $=24, \mathrm{~W}=1.9, \mathrm{P}=0.16,-\mathrm{G} \times \mathrm{M}$ : d.f. $=24, \mathrm{~W}=0.0, \mathrm{P}=0.97)$. The exclusion of flying predators and parasitoids did not affect web densities $($ d.f. $=24, \mathrm{~W}=0.0, \mathrm{P}=$ $0.87)$. 
Table 1: Densities of aphids and their natural enemies in mulched and unmulched wheat without exclusion of predators. Aphids, parasitoids and flying predators: Individuals per 100 shoots. Web spiders: Individuals per square meter. Other ground-dwelling predators: Individuals captured per unenclosed pitfall trap on 4 days between June 14th and June 31 st. June 25 th: $n=8$ replications, including the flying enemy exclusions before cages were installed. Other dates: $n=4$ replications. Arithmetic means $\pm \mathrm{SE}$.

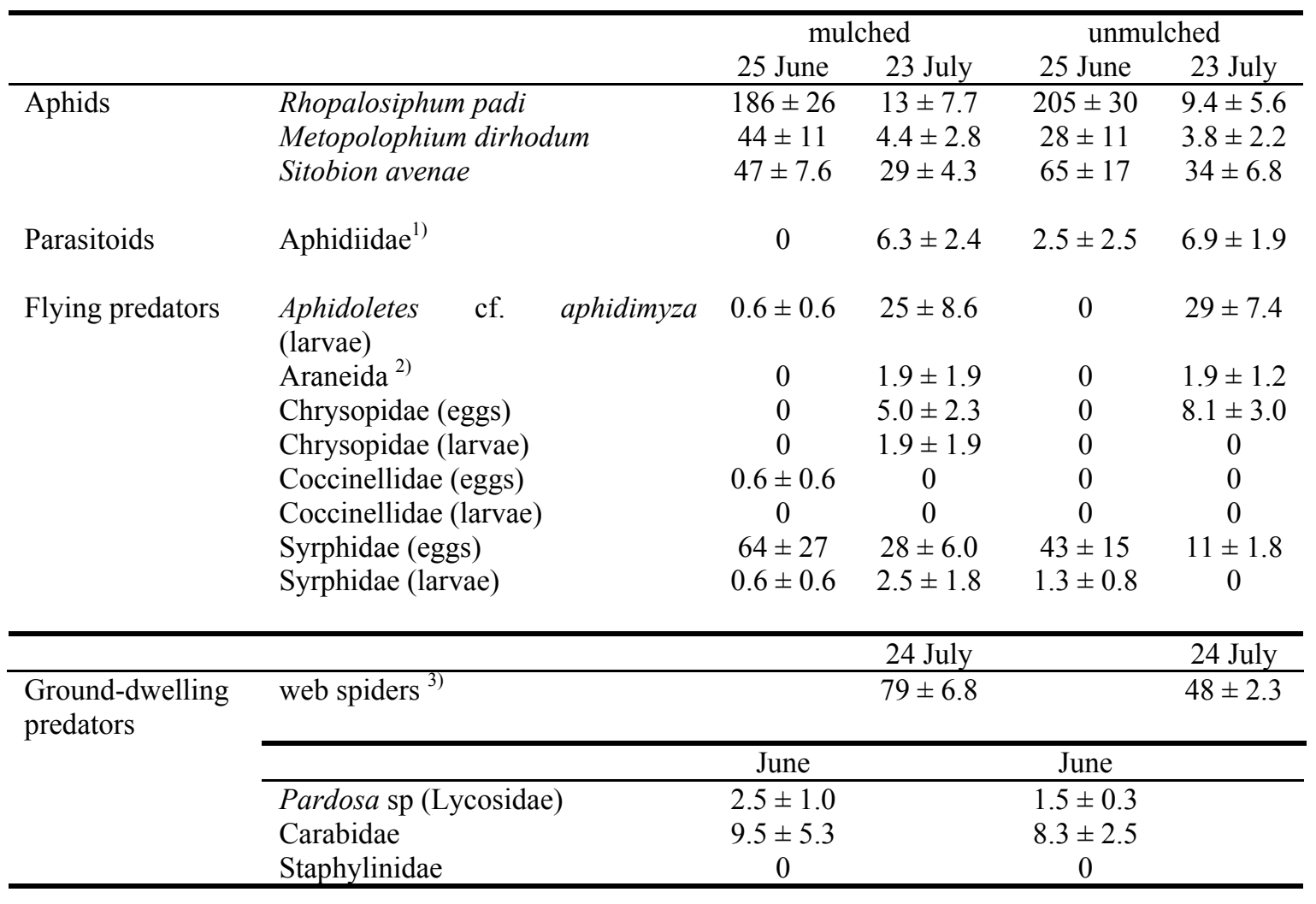

\footnotetext{
1)Aphid mummies: Aphidius sp. and Praon sp.

${ }^{2)}$ Individuals associated with shoots: mostly Linyphiidae

${ }^{3)}$ Mostly the Tenuiphantes tenuis (Blackwall) and Bathyphantes gracilis (Blackwall) (both Linyphiidae)
}

\section{Flying aphid enemies}

Neither flying predators nor parasitoids were significantly affected by mulch or the removal of ground-dwelling predators. Contrastingly, all flying predators and parasitoids had lower densities in treatment -F on July 23rd, though only gall midge larvae and parasitoid mummies were frequent enough for analysis. Numbers of hoverfly eggs were reduced in the flying predator plus parasitoid exclusion by $96 \%(0.8 \pm 0.4$ versus $19.5 \pm 3.2$ per 100 shoots). Hoverfly larvae had $93 \%$ lower numbers in the flying predator exclusion $(0.2 \pm 0.2$ versus $2.2 \pm 0.7$ per 100 shoots $)$. Lacewing eggs (Neuroptera: Chrysopidae) were found only in plots open to flying predators ( 0 versus $5.2 \pm 1.3$ per 100 shoots). The abundance of gall-midge larvae was $75 \%$ lower in treatment $-\mathrm{F}(6.7 \pm 2.1$ versus $27.2 \pm 3.3$ per 100 shoots, d.f. $=24, \mathrm{~W}=18.0, \mathrm{P}<0.001)$. The number of mummified aphids was reduced in the flying predator plus parasitoid 
exclosure by $45 \%(3.8 \pm 0.7$ versus $6.9 \pm 1.0$ per 100 shoots, d.f. $=24, \mathrm{~W}=6.3, \mathrm{P}=$ 0.012). Sitobion avenae was the only aphid species parasitized in considerable numbers (July 23rd: $14.2 \%$ parasitism, mummies in 25 out of 32 plots), and parasitism was reduced by half in treatment $-\mathrm{F}(9.8 \pm 2.2$ versus $18.7 \pm 3.4 \%)$. Rhopalosiphum padi was only parasitized at $0.44 \%$ (July 23rd). Metopolophium dirhodum (Walker) showed $16.4 \%$ parasitism on July $23 \mathrm{rd}$, but mummies were found only in 7 out of 32 plots.

\section{Response of aphids}

Mean aphid densities decreased from $366 \pm 27$ individuals per 100 shoots on June 25th to $83 \pm 7.6$ individuals per 100 shoots on July 23rd (all treatments combined). Rhopalosiphum padi was dominant at both dates $(73 \%$ and $50 \%$ of all aphids, respectively), followed by Sitobion avenae (15\% and $43 \%$ ) and Metopolophium dirhodum (12\% and $6 \%$ ). On June 25th, aphid densities were on average $55 \%$ higher in the exclusion of ground-dwelling predators (Fig. 1A, Table 2). Mulching lowered their densities by $25 \%$. Mulch seemed to affect aphids only in the plots with reduced densities of ground-dwelling predators (Fig. 1A), but the interaction term between ground-dwelling predators and mulch was only marginally significant (Table 2). On July 23rd, aphid densities in ground-dwelling predator exclusions were still elevated by $40 \%$ (Table 2). The effect of ground-dwelling predator removal appeared to be restricted to the plots without mulch (Fig. 1B), but there was no significant interaction between $-\mathrm{G}$ and mulching (Table 2). Exclusions of flying predators plus parasitoids retained $94 \%$ higher aphid populations than controls (Fig. 1B, Table 2). No signs of interaction occurred between flying aphid enemy exclusion and the other treatments.
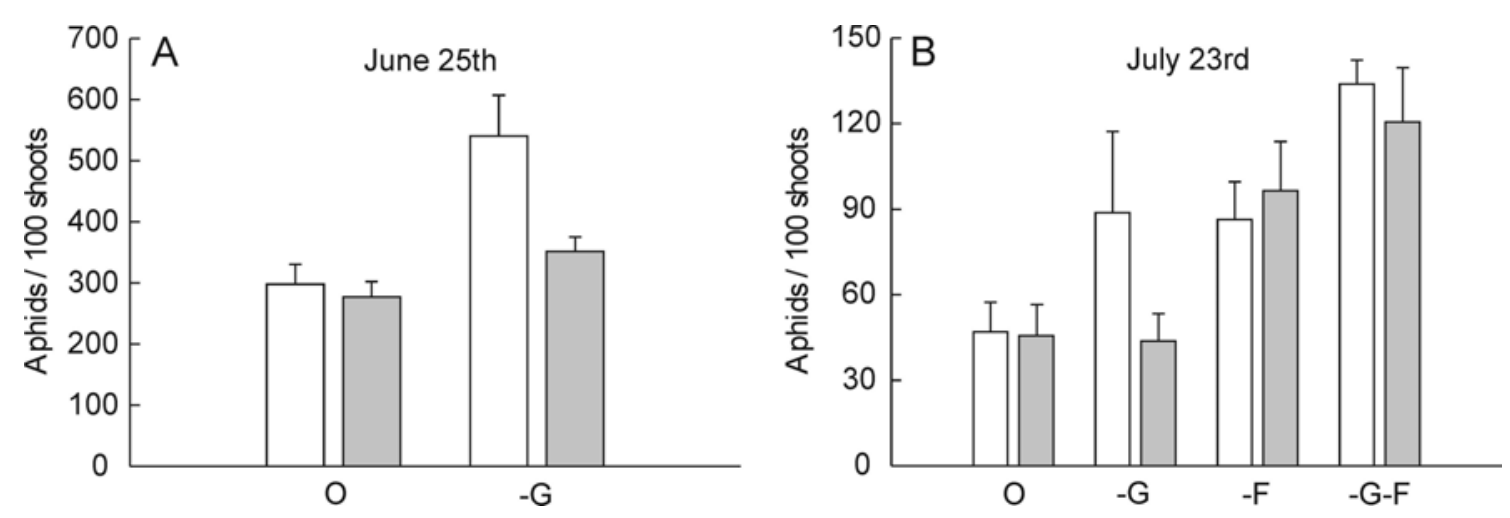

Figure 1: Aphid densities (Rhopalosiphum padi, Metopolophium dirhodum and Sitobion avenae) in mulched (grey columns) and unmulched (open columns) wheat on (A) June 25th (flowering) and (B) July 23rd (milk ripening). $0=$ open control, $-\mathrm{G}=$ ground-dwelling predators excluded, $-\mathrm{F}=$ flying predators and parasitoids excluded. For test statistics see Table 2. 
Table 2: Response of aphid densities to mulch (M) and natural enemy exclusion. - $\mathrm{G}=$ ground-dwelling predator exclusion, $-\mathrm{F}=$ flying predator and parasitoid exclusion. For aphid densities see Fig. 1.

\begin{tabular}{llccc}
\hline Date & Factor & d.f. & W & P \\
\hline June $25^{\text {th }}$ & $-\mathrm{G}$ & 1 & 15.2 & $<0.001$ \\
& $\mathrm{M}$ & 1 & 5.5 & 0.019 \\
& $-\mathrm{G} \times \mathrm{M}$ & 1 & 2.8 & 0.095 \\
& error & 28 & & \\
\hline July $23^{\text {rd }}$ & $-\mathrm{G}$ & 1 & 4.4 & 0.037 \\
& $-\mathrm{F}$ & 1 & 21.8 & $<0.001$ \\
& $\mathrm{M}$ & 1 & 1.4 & 0.23 \\
& $-\mathrm{G} \times-\mathrm{F}$ & 1 & 0.0 & 0.90 \\
& $-\mathrm{G} \times \mathrm{M}$ & 1 & 2.4 & 0.12 \\
& $-\mathrm{F} \times \mathrm{M}$ & 1 & 1.5 & 0.22 \\
& $-\mathrm{G} \times-\mathrm{F} \times \mathrm{M}$ & 1 & 0.6 & 0.43 \\
\hline
\end{tabular}

\section{Discussion}

\section{Ground-dwelling predators}

The capture of $87 \%$ more spiders in mulched plots suggest a positive effect of mulch on spider densities, as expected (Riechert \& Bishop, 1990; Rypstra et al., 1999). However, mulch did not increase the abundance of families other than Linyphiidae and Lycosidae. A diverse spider community (including Gnaphosidae, Thomisidae, and other families) inhabited the fallow-like vegetation surrounding the experimental field. Presumably, the time since mulch was deployed did not suffice for colonization. In contrast to spiders, ground beetle densities did not appear to be enhanced by mulch, possibly due to the short duration since the mulch was applied (Humphreys \& Mowat, 1994). In the ground-dwelling predator exclusions, a considerable proportion of spiders and beetles have been removed with pitfall traps and by hand. Although spiders and beetles may have re-colonized the plots through the air, their densities should have been at least temporarily depressed (Holland, 1998; Schmidt et al., 2003), as indicated by the 16\% lower web densities in the exclusion plots at the end of the experiment, twenty days after the last web spider manipulation had occurred.

\section{Flying aphid enemies}

The high effectiveness of the exclusion cages in reducing local densities of flying predators and parasitoids was obvious on July 23rd. All flying aphid enemies had reduced numbers inside the exclusion cages compared to open controls. Aphid mummies occurred at $45 \%$ lower densities in the cages, indicating that the glue-covered wire mesh was a significant obstacle even to small parasitoid wasps that would have 
physically fit through the $8 \mathrm{~mm}$ openings. The difference in abundance between inside and outside the cages was still more distinct for the larger aphid enemies, culminating in the complete absence of lacewing eggs in the exclusions.

\section{Response of aphids}

Aphid populations were suppressed by both ground-dwelling and flying predators in our experiment. Ground-dwelling predators may prey on aphids either directly on the ground, as aphids regularly drop from the vegetation (Winder, 1990; Duffield et al., 1996), or by climbing the vegetation, e.g. at night (Vickerman \& Sunderland, 1975). Straw mulch enhanced ground-dwelling spiders and reduced aphid densities at the first sampling date (Table 2). This suggests that aphid suppression in mulched plots was due to spiders, as ground beetles, which may also control cereal aphids (Lang, 2003), did not respond to mulch in our experiment. The weaker response of aphids to grounddwelling predator removal in the presence of mulch (Fig. 1) may then reflect that the predator exclusion was not complete, but allowed more spiders to remain in mulched than in unmulched removal plots. However, the mean aphid densities in Figure 1 also suggest that, despite a significant negative effect of mulch on aphids, their densities were only slightly reduced in the mulched plots without ground predator manipulation. As the interaction term between $-\mathrm{G}$ and mulching was not significant, this may have been caused by the strong variability in aphid densities. Otherwise, the presumably enhanced spider densities in the mulched open plots were either less efficient at preying on aphids, or additional processes such as intraguild interference played a role (Lang, 2003). By increasing the structural complexity at the soil surface, mulch may reduce the probability of encounter between predators and aphids (compare Finke \& Denno, 2002). Overall, our results indicate that the bare soil can both constrain spider abundance and increase aphid infestation in arable crops. The generality and mechanism of this observation need further investigation, for example using carbon isotopes to trace trophic pathways (Staddon 2004).

The positive effect of flying enemy exclusion on aphid densities did not interact with mulch or the exclusion of ground-dwelling predators. Although there was considerable parasitism (about $15 \%$ ) of the two rarer aphid species, the effects of flying aphid enemies in our experiment cannot be attributed to parasitoid wasps alone. Higher aphid densities in plots with flying enemy exclusion originated mainly from the higher survival of Rhopalosiphum padi, which was little parasitized. Therefore, dipterans with 
aphidophagous larvae probably exerted the highest impact on aphid populations in July, because, in contrast to spiders, their densities responded to the exclusion of flying enemies. Larvae of the gall midge Aphidoletes cf. aphidimyza were found in the highest numbers. The density of hoverfly larvae was an order of magnitude lower. However, hoverfly larvae are known to vigorously feed on aphids (Freier et al., 1997), and their densities were possibly underestimated because most species are nocturnal and conceal during daytime (Vickerman \& Sunderland, 1975; Holmes, 1984). Presumably, both hoverflies and gall midges reduced aphid abundance in control treatments. More detailed studies are necessary to assess the relative importance of these two aphid enemies. Besides its employment for aphid control in greenhouses (van Schelt \& Mulder, 2000), Aphidoletes aphidimyza is little known and deserves more attention as a control agent in arable fields, as well.

In conclusion, our experiment suggests that ground-dwelling predators and dipteran larvae reduced cereal aphid infestations in spring wheat. As the two groups of natural enemies did not interfere, combinations of multiple predators and parasitoids appear to protect crops from pests most effectively. Mulch enhanced ground-dwelling spiders and reduced aphid infestation, suggesting that enrichment of the soil surface with litter in crop fields can improve pest control. Conservation or application of crop residues to arable fields is thus a promising cultural technique to enhance natural forces of pest regulation.

\section{Acknowledgements}

Comments by James T. Cronin, Nick J. Mills, Stefan Scheu and three anonymous reviewers greatly improved this manuscript. The study is part of the BIOPLEX project (Biodiversity and spatial complexity in agricultural landscapes under global change), funded by the BIOLOG program of the German Ministry for Research and Education (BMBF). MHS was supported by the German National Academic Foundation (Studienstiftung des deutschen Volkes). 


\section{Introduction}

Historically, biological control has primarily relied on local facilitation of natural enemy populations, but recent studies have found strong effects of landscape structure on the dynamic interactions between pests and their natural enemies. Case studies in arable crops show how predators and parasitoids of major pests have been enhanced by the presence of a high percentage of non-crop habitats in the landscape. We explore the major challenge of understanding the coaction of landscape effects on both pests and their multiple enemies, and of identifying applicable measures for landscape management that enhances natural pest control.

The importance of the spatial context for interactions between plants, herbivores, and their enemies has been increasingly recognised during the past decades (Ricklefs 1987, Kareiva 1990a,b). Because of the high mobility of many organisms, the spatial scale of many studies has widened to include processes active over whole landscapes. Theory is successfully expanding to consider population dynamics and plant-pest-enemy interactions at a landscape scale (Kareiva \& Wennegren 1995, Holt \& Hochberg 2001, Holt 2002, Tscharntke \& Brandl 2004). In contrast, conducting manipulative experiments with independent landscape replicates is difficult, though scaling-up from the local to the landscape level may provide new insights (e.g. Kruess \& Tscharntke 1994, 2000, With \& Christ 1995, Roland \& Taylor 1997, Cappuccino et al. 1998, van Nouhuys \& Hanski 2002, With et al. 2002). Here, we focus on the current development of large-scale studies demonstrating landscape effects on processes relevant for biological control.

The applicability of classical spatial concepts such as island biogeography or metapopulation theory to annual crops is limited (Tscharntke \& Brandl 2004). Impoverishment of biodiversity is typical for simplified agricultural landscapes dominated by few types of annual crops (Stoate et al. 2001, Benton et al. 2003). In such landscapes, crop fields are not isolated from each other, but may be distant from less disturbed habitats that are potential sources of immigrants. Many organisms depend, at some life stage, on resources that annual crops lack and such species may be rare or absent in crop-dominated landscapes if their dispersal power is smaller than the distance to these resources (Tscharntke \& Brandl 2004). For example, dispersal limitation of 
many parasitoids leads to reduced build-up of populations in crop fields. When natural enemies of herbivores become locally impoverished, their host or prey may be released from natural control and increasingly damage crops. Essential resources for biocontrol agents that are usually not available in annually ploughed fields are pollen and nectar sources for adults of parasitoid Hymenoptera and Diptera, or perennial plant cover and an undisturbed soil surface for overwintering and larval development of a wide array of insects and spiders (Landis et al. 2000, Tscharntke 2000, Gurr et al. 2003). The few existing studies with replicated landscapes mostly found strong effects of landscape context on local community structure and interactions (Roland \& Taylor 1997, Thies \& Tscharntke 1999, Östman et al. 2001, Elliott et al. 2002, Steffan-Dewenter et al. 2002, but see Menalled et al. 1999). Considering the landscape context adds exciting new aspects to biological control, some of which will be described in this chapter.

\section{Two case studies: cereals and oilseed rape}

\section{Study area and organisms}

The case studies presented here deal with pest-natural enemy interactions in oilseed rape and winter wheat, which are two major crop species in many temperate areas such as the study region around the city of Göttingen, Germany. In this region, structurally simple landscapes dominated by annual crops (covering $>95 \%$ ) are geographically interspersed with structurally complex landscapes comprising a mixture of crop fields, grasslands, fallows, forests and other non-crop elements (>50\% non-crop area). Arable land covered $43 \%$ of the area, $36 \%$ of which was planted to winter wheat (Triticum aestivum) and 14\% to winter oilseed rape (Brassica napus). Forests covered 33\%, and grasslands $7.5 \%$ of the area (Niedersächsisches Landesamt für Statistik, pers. comm.). Interactions between major insect pests and their natural enemies were studied in relation to landscape context in 15 (rape) and 18 (wheat) non-overlapping landscape sectors, respectively, covering a gradient of structural complexity. Thereby, the percentage of (annually ploughed) arable land was a good indicator for structural complexity, showing close correlations with other parameters of landscape composition and configuration (Table 1). Low percentages of arable land were associated with high values of the perimeter-to-area ratio, meaning that fields are small and large amounts of field edges could enhance immigration of species whose occurrence in fields is limited by dispersal. At the same time, percentage of arable land was negatively correlated to the diversity of land-use types and to percentage grassland. Depending on species, 
grassland or other non-crop habitats provide potential overwintering habitats (Landis et al. 2000, Sunderland \& Samu 2000).

Table 1: Correlation coefficients between the percentage of arable land, percentage grassland, perimeterto-area ratio (PAR) and the Shannon-Wiener diversity of land-use types (HS) in the eighteen studied landscape sectors of $1 \times 1 \mathrm{~km}$. All correlations are significant at $\mathrm{p}<0.01$.

\begin{tabular}{lccc}
\hline & PAR & HS & grassland (\%) \\
\hline arable land (\%) & -0.81 & -0.94 & -0.66 \\
grassland (\%) & 0.84 & 0.77 & \\
HS & 0.90 & & \\
\hline
\end{tabular}

In oilseed rape, the pollen beetle Meligethes aeneus (Coleoptera: Nitidulidae) is one of the major pest species. Pollen feeding of the adults inhibits pod and seed development, leading to economically important crop damage. Larvae of the pollen beetles, which develop in the rape flowers, are mainly attacked by parasitoid wasps (Hymenoptera: Ichneumonidae). Pollen beetle herbivory was measured as percentage of destroyed buds, and its mortality due to parasitism was recorded by dissecting last instar larvae for the presence of parasitoid eggs (see Thies et al. 2003).

Cereal aphids (Homoptera: Aphididae) are dominant herbivores in winter wheat, causing economic damage in some years, partly due to transmission of viruses (BYDV, Bruehl 1961). Three species are common in the study region, of which Sitobion avenae is usually the most abundant, followed by Metopolophium dirhodum and Rhopalosiphum padi. Natural enemies of cereal aphids were quantified. Parasitoid wasps (Hymenoptera: Aphidiidae) and spiders (Araneae: mostly Linyphiidae) were found to be important antagonists of cereal aphids in the study region (Schmidt et al. 2003).

\section{Enhanced biological control in complex landscapes}

Plant damage by the rape pollen beetle and its parasitism by wasps were studied in winter rape fields within the fifteen landscapes varying from structurally simple to complex. Additionally, potted summer rape plants were raised under standardised conditions and exposed in grassy field margin strips in each landscape. This was done to circumvent confounding influences such as local soil type, which may vary between landscapes. The full-flowering period of rape was in May (fields) and June (potted 
plants). Parasitism of pollen beetles increased with the percentage of non-crop area in the surrounding landscape on both the potted rape plants (Fig. 1A) and in the rape fields (Thies \& Tscharntke 1999). Correspondingly, the percentage of buds destroyed by the beetle declined with increasing landscape complexity (Fig. 1B). In landscapes with more than $20 \%$ non-crop area, parasitism exceeded the threshold value of $32-36 \%$, below which a success in classical biological control has never been found (Hawkins and Cornell 1994).
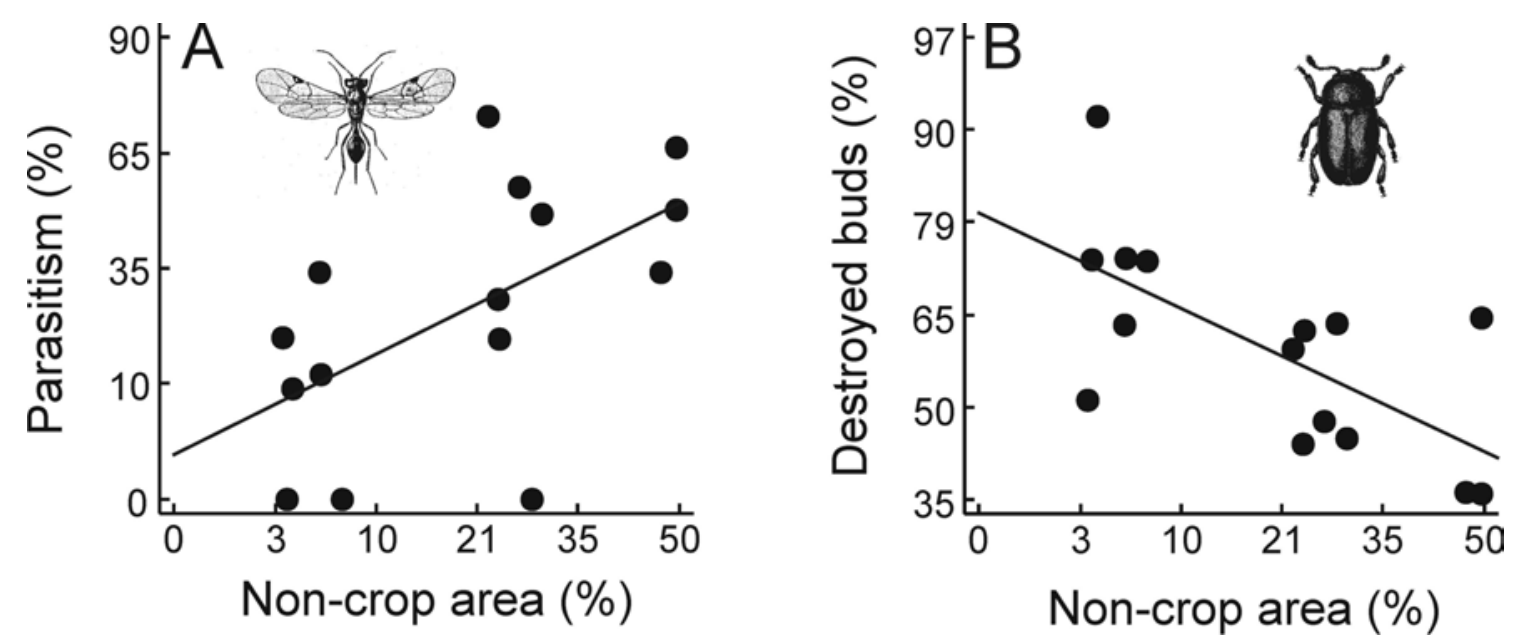

Figure 1: (A) Percentage parasitism of rape pollen beetles by wasps in relation to the percentage of noncrop habitats in a circular sector of $1.5 \mathrm{~km}$ diameter around the experimental plot. $\mathrm{y}=7.75+0.87 \mathrm{x}, \mathrm{n}=$ $15, r=0.57, p=0.02$. (B) Percentage of buds destroyed by rape pollen beetles in relation to the percentage of non-crop habitats in a circular sector of $1.5 \mathrm{~km}$ diameter around the experimental plot. $\mathrm{y}=$ $70.8-0.51 \mathrm{x}, \mathrm{n}=15, \mathrm{r}=0.66, \mathrm{p}=0.007$. Reprinted with permission from Thies \& Tscharntke, Science 285:893-895. Copyright 1999 AAAS.

\section{Functional scales of landscape processes}

A basic question in the study of landscape effects is at which scale they are manifested. Dispersal and foraging distances are hard to measure for many agricultural pests and antagonists, because they are too small, too abundant, or too mobile for mark-recapture experiments. A possible approach for specialists is to expose food plants or hosts at known distances to the next population, and measure their colonisation (e.g. Kruess \& Tscharntke 1994, 2000). However, rape pollen beetles, cereal aphids and their natural enemies also live on wild crucifers and grasses, respectively, and hence in many noncrop habitats (Charpentier 1985, Dean 1974, Horstmann 1981). Their widespread occurrence complicates determining the distance to the nearest population. However, the response of parameters such as parasitism to non-crop habitats in the surrounding landscape renders an alternative approach possible. Landscape metrics can be calculated 
for various diameters around the study sites (Fig. 2A), most straightforwardly with a geographic information system (GIS). Correlations for the organisms' response to landscape features can be calculated across a range of spatial scales. Results of this approach show that the strength of such relations, measured by the coefficient of determination $\mathrm{r}^{2}$, peaks at distinct scales (Fig. 2B). This is the functional spatial scale at which a species responds to the landscape context, and likely reflects its foraging range. The approach can be used to test the hypothesis that the spatial scale experienced by organisms widens with increasing trophic level (Holt 1996), or body size (Ritchie \& Olff 1999). For the rape pollen beetle system, a larger spatial domain for the parasitoids than for herbivores was not found. Functional scales of both herbivory and their parasitism by wasps lay at $1.5 \mathrm{~km}$ diameter (Fig. 2B; Thies et al. 2003). In contrast, parasitoids of cereal aphids are influenced by landscape structure at smaller scales (0.5$1 \mathrm{~km}$ diameter), probably related to their smaller body size (CT, unpublished data), whereas strong dispersers such as sheetweb weaving spiders (Araneae: Linyphiidae) respond to landscape structure at larger scales of about 2-3km (MHS, unpublished data). Densities of pollinators revealed a differentiation of functional scales from small $(0.5 \mathrm{~km}$ for solitary wild bees) to large (6km for honey bees) (Steffan-Dewenter et al. 2002).
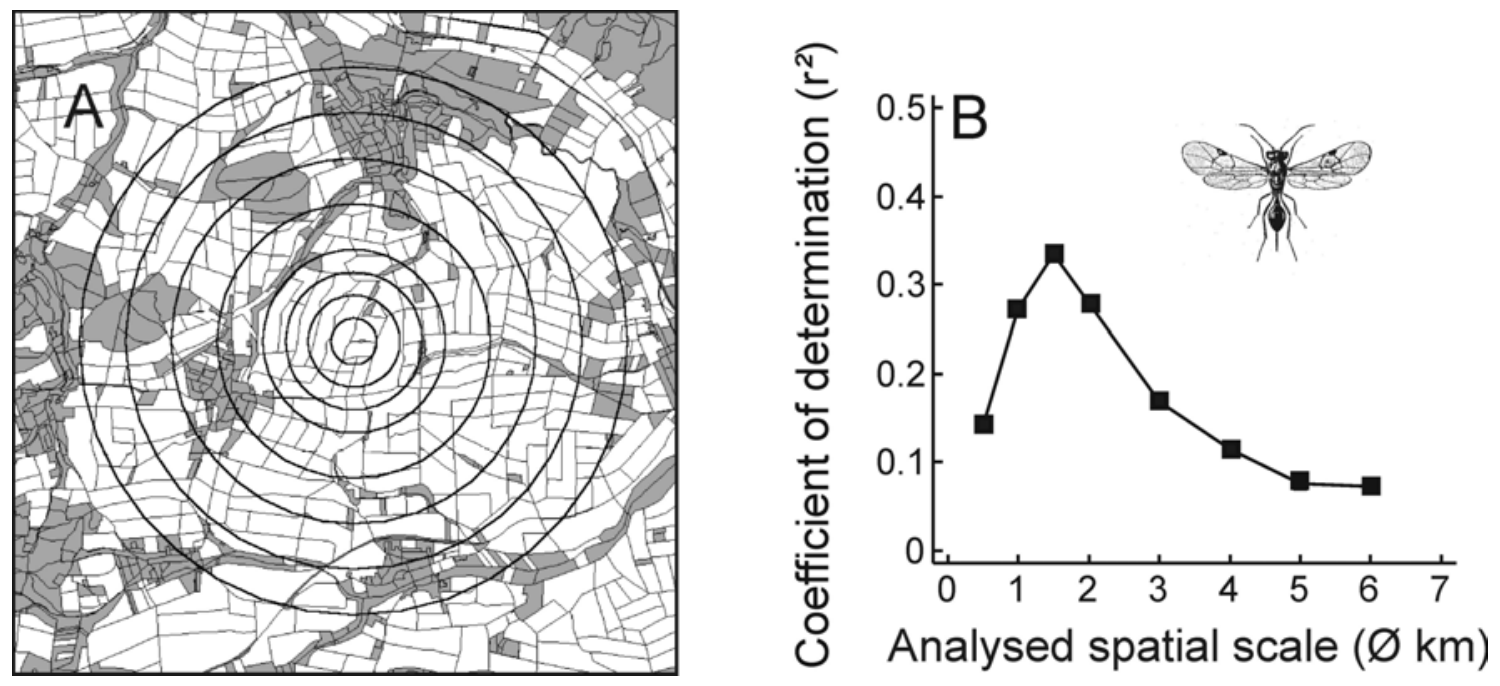

Figure 2: (A) Calculating landscape metrics for nested sectors of varied size around one out of fifteen study fields (white $=$ arable crops; grey $=$ non-crop habitats, diameters ranging from $0.5-6 \mathrm{~km}$ ). (B) Comparing coefficients of determination from correlations between parasitism and percentage of noncrop within diameters between 0.5 to $6 \mathrm{~km}$ around the study plots (single correlations analogous to Fig. 1A). The functional scale for parasitism can be inferred at $1.5 \mathrm{~km}$. Reprinted with permission from Thies et al. (2003). 


\section{Temporal dynamics}

Agricultural landscapes are subject to yearly changes in land use resulting from crop rotations and changes in political schemes and subsidies. This may affect pest and natural enemy populations, which further vary with climate, annual phenologies and interspecific interactions (Holt \& Barfield 2003). Particularly, crop rotations continuously change the arrangement and composition of crop types to prevent selective depletion of soil nutrients and local build-up of (mostly soil-borne) pest populations. Large-scale consequences of crop rotations and the resulting change in habitat area were studied for the rape pollen beetle and its parasitoids. Herbivory (\% destroyed buds) and parasitism were negatively correlated to the change in rape-crop area relative to the preceding year (Thies et al. in review). In landscapes where the percentage of rape crop had decreased, rape fields showed higher levels of both the attack by pollen beetles and parasitism. In landscapes where rape-crop area had expanded, herbivory and parasitism were reduced. This indicates crowding and dilution effects resulting from changed availabilities of food resources at the landscape level. A large-scale bottom-up effect of resource availability acts on pollen beetles in addition to the top-down effect induced by landscape structure via parasitism.

An example of a very dynamic system, probably driven by the availability of overwintering habitat and weather, is the colonisation of arable fields by sheetwebweaving spiders. Spider densities in wheat fields were low relative to grasslands in early spring, but rose considerably in late spring, especially in grassland-rich landscapes. This temporarily led to more than four times higher spider abundances in wheat fields with a high percentage of grassland in the surrounding landscape than in wheat fields with a grassland-poor surrounding (MHS, unpublished data). A similar variation in spider densities has been shown to affect cereal aphid populations in field experiments (Schmidt et al. 2003), thereby suggesting that aphid population growth can be reduced by high spider densities in grassland-rich landscapes. However, the differences in spider abundances between simple and complex landscapes were only temporary, because populations in simple landscapes caught up within few weeks. This may have been due to reproduction or ongoing long-distance dispersal in concert with limited carrying capacity of the habitat (competition for web sites). Moreover, the timing of spider immigration into crops varied considerably between years, probably being influenced by the suitable weather for the ballooning dispersal of these species (Vugts \& van Wingerenden 1976). 


\section{Interactions between local and regional diversification}

Non-crop vegetation, such as field margins, sown flower strips, beetle banks, or conservation headlands, can enhance populations of beneficials in adjacent crops (Landis et al. 2000, Marshall \& Moonen 2002, Pfiffner \& Wyss, this volume). It contributes to diversification at the landscape scale. However, its effect may depend on landscape structure. This has been found in the rape pollen beetle system (Tscharntke et al. 2002). Parasitism of pollen beetles was higher near the crop field edge, near the parasitoids' overwintering habitats, and decreased towards the centre of the field. However, this was only true in landscapes dominated by annual crops $(<20 \%$ non-crop area). In landscapes with a high percentage of permanent non-crop area, such edge effects disappeared (Fig. 3), presumably due to the high overall density of the parasitoids. Thus, decisions about the placement of such diversification measures should consider that the local benefit is probably higher in structurally poor landscapes. Local orientation of management practices appears to be necessary and useful only in simple landscapes. However, for the conservation of biodiversity including the many rare or sensitive species, creation of new habitats may be more effective in structurally rich landscapes where such species are still present. Consequently, evaluations of local diversification measures should take the landscape context into account.

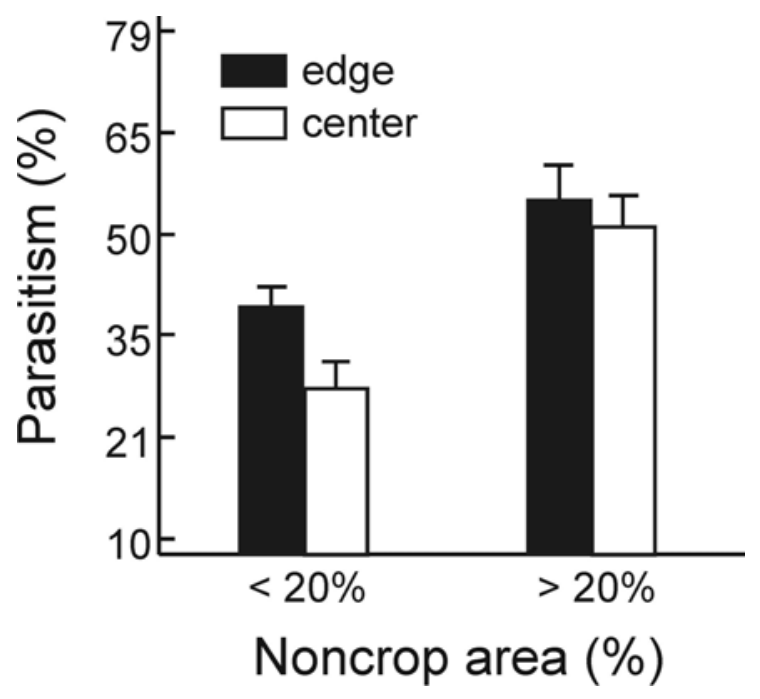

Figure 3: Parasitism ( $\pm 1 \mathrm{SE}$ ) of the rape pollen beetle in relation to the percentage of non-crop area in the agricultural landscape. Parasitism significantly decreased from the edge to the centre of the field in landscapes with $<20 \%$ of non-crop area $(\mathrm{n}=16, \mathrm{~F}=6.0, \mathrm{p}=0.028)$, whereas parasitism did not decrease from the edge to the centre in landscapes with $>20 \%$ of non-crop area $(\mathrm{n}=14, \mathrm{~F}=0.38, \mathrm{p}=0.55)$. Reprinted with permission from Tscharntke et al. (2002). 


\section{Counteracting processes}

The landscape context can influence pests and their multiple enemies at the same time. Under certain conditions, the resulting interactions may impede biological control. For example, cereal aphids overwinter predominantly in perennial habitats (Dean 1974). Despite the fact that these aphids can bridge tens or even hundreds of kilometres as aerial plankton, infestation levels in wheat where higher in structurally complex landscapes in June (CT, unpublished data). Hence, two counteractive processes are caused by structural complexity in the landscape: increased aphid colonisation, but also increased aphid control by parasitoid wasps and spiders. In both the aphids and their enemies, the increased availability of alternative resources may have enhanced early populations, but aphid abundances were no longer correlated to landscape complexity later in the season. Possibly, enhanced control by their natural enemies adjusted the initially higher aphid abundances in complex landscapes to similar levels as in structurally poor landscapes. These preliminary results point at extensive interactions that are likely to be driven by landscape complexity. Counterintuitive outcomes may also occur in the case of strong interference between multiple predators (Sih et al. 1998). Snyder and Ives (2001) showed how ground beetles (Coleoptera: Carabidae), which themselves were able to reduce aphid densities, disrupted aphid control by parasitoid wasps through preying selectively on the parasitised aphids (mummies) in alfalfa. In the long term, parasitoids alone suppressed aphid populations more effectively than did ground beetles alone, or both enemies in combination. Thereby, landscape management in favour of both enemy groups would prove less efficient than selective facilitation of the parasitoid wasps. Contrastingly, in the case of cereal aphid suppression, no interference between parasitoid wasps and spiders was found, and both enemy groups together produced the highest level of aphid control (Schmidt et al. 2003). Direct impacts of landscape diversification on pests and emergent impacts of multiple enemies need consideration in landscape manipulations for pest management.

\section{Conclusions}

The recent focus on landscape context of pest-natural enemy interactions suggests that a purely local orientation of biological control is not sufficient. Examples from oilseed rape and winter wheat underline the importance of non-crop habitats for natural enemies of major pest species. Also, the effectiveness of local habitat diversification (e.g. field margin strips) was affected by the structure of the surrounding landscape. Our results 
indicate that many natural enemies of major pest species depend on other, less disturbed, habitats than the crop itself. This is a substantial argument for the conservation or creation of refuge habitats such as grasslands, fallows, or other species rich habitats in agricultural landscapes. Despite these emerging patterns, our knowledge is still fragmentary. A major challenge arises when pests and their multiple enemies are concurrently affected by landscape structure, leading to counteractive processes. In such cases, specific conditions for pest inhibition and facilitation of beneficials need to be detected. We need additional well-designed, long-term field studies on a landscape scale, accompanied by theoretical work, to better understand patterns and mechanisms of food-web interactions in time and space.

\section{Acknowledgements}

Geoff M. Gurr, Robert D. Holt and Douglas A. Landis provided valuable comments on an earlier draft of this manuscript. We are grateful to Christoph Bürger, Doreen Gabriel, Indra Roschewitz and Ulrich Thewes for help in the field and processing of landscape data. The work greatly profited from collaboration with Jens Dauber, Tobias Purtauf and Volkmar Wolters within the BIOPLEX project (Biodiversity and spatial complexity in agricultural landscapes under global change), funded by the German Ministry for Research and Education (BMBF). Further support came from the German Science Foundation (Deutsche Forschungsgemeinschaft) and from the German National Academic Foundation (Studienstiftung des deutschen Volkes). 


\section{Literaturverzeichnis}

Aebischer N.H. (1991) Twenty years of monitoring invertebrates and weeds in cereal fields in Sussex. In: The Ecology of Temperate Cereal Fields. 32nd Symposium of the British Ecological Society (eds Firbank I.G., Carter N., Darbyshire J.F. \& Potts G.R.), pp. 305-331. Blackwell Scientific Publications, Oxford.

Alderweireldt M. (1994) Prey selection and prey capture strategies of Linyphiid spiders in highinput agricultural fields. Bulletin of the British Arachnological Society 9, 300-308.

Altieri M.A., Cure J.R. \& Garcia M.A. (1993) The role and enhancement of parasitic hymenoptera biodiversity in agroecosystems. In: Hymenoptera and Biodiversity (ed LaSalle J \& Gauld ID), pp. 257-275. C A B International, Wallingford UK.

Amir J. \& Sinclair T.R. (1996) A straw mulch system to allow continuous wheat production in an arid climate. Field Crops Research 47, 21-31.

Benton T.G., Vickery J.A. \& Wilson J.D. (2003) Farmland biodiversity: is habitat heterogeneity the key? Trends in Ecology and Evolution 18, 182-188.

Bishop L. \& Riechert S.E. (1990) Spider colonization of agroecosystems: mode and source. Environmental Entomology 19, 1738-1745.

Blick T., Hänggi A. \& Thaler K. (2002) Checklist of the arachnids of Germany, Switzerland, Austria, Belgium and the Netherlands (Arachnida: Araneae, Opiliones, Pseudoscorpiones, Scorpiones, Palpigradi). Version 2002 June 1. Internet: http://www.AraGes.de/checklist_e.html.

Blick T., Pfiffner L. \& Luka H. (2000) Epigäische Spinnen auf Äckern der Nordwest-Schweiz im mitteleuropäischen Vergleich (Arachnida: Araneae). Mitteilungen der Deutschen Gesellschaft für Allgemeine und Angewandte Entomologie 12, 267-278.

Bolaños A. (2003) Spider assemblages and habitat bindings in Central Europe. Verlag Agrarökologie, Bern.

Bonte D., Baert L. \& Maelfait J.-P. (2002) Spider assemblage structure and stability in a heterogenous coastal dune system (Belgium). Journal of Arachnology 30, 331-343.

Booij C.J.H. \& Noorlander J. (1992) Farming systems and insect predators. Agriculture, Ecosystems and Environment 40, 125-135.

Booij C.J.H., Topping C.J., Szysko J., van Dijk Th., Paoletti M. \& Helenius J. (1996) Assessment of survival and mortality factors in field populations of beneficial arthropods. Acta Jutlandica 71, 69-78.

Bruehl G.W. (1961) Barley yellow dwarf, a virus disease of cereals and grasses. Monograph of the American Phytopathological Society I.

Buerkert A., Bationo A. \& Dossa K. (2000) Mechanisms of residue mulch-introduced cereal growth in West Africa. Soil Science Society of America Journal 64, 346-358.

Cappuccino N., Lavertu D., Bergeron Y. \& Régnière J. (1998) Spruce budworm impact, abundance and parasitism rate in a patchy landscape. Oecologia 114, 236-242.

Carter N., Gardner S., Fraser A.M. \& Adams T.H.L. (1982) The role of natural enemies in cereal aphid population dynamics. Annals of Applied Biology 101, 190-195.

Chambers R.J., Sunderland K.D., Wyatt I.J. \& Vickerman G.P. (1983) The effects of predator exclusion and caging on cereal aphids in winter wheat. Journal of Applied Ecology 20, 209224. 
Charpentier R. (1985) Host plant-selection by the pollen beetle Meligethes aeneus. Entomologia Experimentalis et Applicata 38, 277-285.

Chen B.R. \& Wise D.H. (1999) Bottom-up limitation of predaceous arthropods in a detritusbased food web. Ecology 80, 761-772.

Chiverton P.A. (1986) Predator density manipulation and its effects on the populations of Rhopalosiphum padi (Hom: Aphididae) in spring barley. Annals of Applied Biology 109, 49-60.

Cole L.J., McCracken D.I., Downie I.S., Dennis P., Foster G.N., Waterhouse T., Murphy K.J., Griffin A.L. \& Kennedy M.P. (2003) Comparing the effects of farming practices on ground beetle (Coleoptera: Carabidae) and spider (Araneae) assemblages of Scottish farmland. Biodiversity and Conservation online.

Colfer R.G. \& Rosenheim J.A. (2001) Predation on immature parasitoids and its impact on aphid suppression. Oecologia 126, 292-304.

Dean G.J. (1974) The overwintering and abundance of cereal aphids. Annals of applied Biology $76,1-7$.

Dinter A. (1997) Density and activity density fluctuations of Oedothorax apicatus (Blackwall) in winter wheat in northern Germany. Acta Jutlandica 72, 87-99.

Dinter A. (1995) Untersuchungen zur Populationsdynamik von Spinnen (Arachnida: Araneae) in Winterweizen und deren Beeinflussung durch insektizide Wirkstoffe. Cuvillier, Göttingen.

Duelli P., Obrist M.K. \& Schmatz D.R. (1999) Biodiversity evaluation in agricultural landscapes: above-ground insects. Agriculture, Ecosystems and Environment 74, 33-64.

Ekschmitt K., Weber M. \& Wolters V. (1997) Spiders, carabids and staphylinids. The ecological potential of predatory macroarthropods. In: Fauna in soil ecosystems (ed Benckiser G.), pp. 307-362. Marcel Decker, New York.

Elliott N.C., Kieckhefer R.W. \& Beck D.A. (2002) Effect of aphids and the surrounding landscape on the abundance of Coccinellidae in cornfields. Biological Control 24, 214-220.

Elliott N.C., Kieckhefer R.W., Lee J.-H. \& French B.W. (1998) Influence of within-field and landscape factors on aphid predator populations in winter wheat. Landscape Ecology 14, 239-252.

Elliott N.C., Kieckhefer R.W., Michels G.J. \& Giles K.L. (2002) Predator abundance in alfalfa fields in relation to aphids, within-field vegetation, and landscape matrix. Environmental Entomology 31, 253-260.

Fagan W.F., Hakim A.L., Ariawan H. \& Yuliyantiningsih S. (1998) Interactions between biological control efforts and insecticide applications in tropical rice agroecosystems: the potential role of intraguild predation. Biological Control 13, 121-126.

Feber R.E., Bell J., Johnson P.J., Firbank L.G. \& Macdonald D.W. (1998) The effects of organic farming on surface-active spider (Araneae) assemblages in wheat in southern England (UK). Journal of Arachnology 26, 190-202.

Finke D.L. \& Denno R.F. (2003) Intra-guild predation relaxes natural enemy impacts on herbivore populations. Ecological Entomology 28, 67-73.

Finke D.L. \& Denno R.F. (2002) Intraguild predation diminished in complex-structured vegetation: implications for prey suppression. Ecology 83, 643-652.

Freier B., Triltsch H., Möwes M. \& Rappaport V. (1997) Der relative Wert von Prädatoren bei der natürlichen Kontrolle von Getreideblattläusen und die Verwendung von Prädatoreinheiten. Nachrichtenbl. Deut. Pflanzenschutzd. 49, 215-222. 
Giller P.S., Ryan B., Kennedy T. \& Connery J. (1995) Aphid-parasitoid interactions in a winter cereal crop: field trials involving insecticide application. Journal of Applied Entomology 119, 233-239.

Glück E. \& Ingrisch S. (1990) The effect of bio-dynamic and conventional agriculture management on Erigoninae and Lycosidae spiders. Journal of Applied Entomology 110, 136-148.

Greenstone M.H., Morgan C.E., Hultsch A.L., Farrow R.A. \& Dowse J.E. (1987) Ballooning spiders in Missouri, USA, and New South Wales, Australia: family and mass distributions. Journal of Arachnology 15, 163-170.

Gurr G.M., Wratten S.D. \& Luna J.M. (2003) Multi-function agricultural biodiversity: pest management and other benefits. Basic and Applied Ecology 4, 107-116.

Halaj J. \& Wise D.H. (2001) Terrestrial trophic cascades: how much do they trickle? The American Naturalist 157, 262-281.

Halley J.M., Thomas C.F.G. \& Jepson P.C. (1996) A model for the spatial dynamics of linyphiid spiders in farmland. Journal of Applied Ecology 33, 471-492.

Hänggi A., Stöckli E. \& Nentwig W. (1995) Habitats of central European spiders. Centre Suisse de cartographie de la faune, Neuchâtel.

Harwood J.D., Sunderland K.D. \& Symondson W.O.C. (2001) Living where the food is: web location by linyphiid spiders in relation to prey availability in winter wheat. Journal of Applied Ecology 38, 88-99.

Hawkins B.A. \& Cornell H.V. (1994) Maximum parasitism rate and sucessful biolocigal control. Science 262, 1886.

Hawkins B.A., Mills N.J., Jervis M.A. \& Price P.W. (1999) Is the biological control of insects a natural phenomenon? Oikos 86, 493-506.

Heimer S. \& Nentwig W. (1991) Spinnen Mitteleuropas: ein Bestimmungsbuch. Parey, Berlin.

Heydemann B. \& Meyer H. (1983) Auswirkungen der Intensivkultur auf die Fauna in den Agrarbiotopen. Schriftreihe des Deutschen Rates für Landespflege 42, 174-191.

Hoelmer K.A., Osborne L.S. \& Yokomi R.K. (1994) Interactions of the whitefly predator Delphastus pusillus (Coleoptera: Coccinellidae) with parasitized sweetpotato whitefly (Homoptera: Aleyrodidae). Ecological Entomology 23, 136-139.

Holland J.M. (1998) The effectiveness of exclusion barriers for polyphagous predatory arthropods in wheat. Bulletin of Entomological Research 88, 305-310.

Holland J.M., Perry J.N. \& Winder L. (1999) The within-field spatial and temporal distribution of arthropods in winter wheat. Bulletin of Entomological Research 89, 499-513.

Holland J.M. \& Thomas S.R. (1997) Quantifying the impact of polyphagous invertebrate predators in controlling cereal aphids and in preventing wheat yield and quality reductions. Annals of Applied Biology 131, 375-397.

Holland J.M., Thomas S.R. \& Hewitt A. (1996) Some effects of polyphagous predators on an outbreak of cereal aphid (Sitobion avenae F.) and orange wheat blossom midge (Sitodoplosis mosellana Gehin). Agriculture, Ecosystems and Environment 59, 181-190.

Holmes P.R. (1984) A field study of the predators of the grain aphid, Sitobion avenae (F.) (Hemiptera: Aphididae), in winter wheat in Britain. Bulletin of entomological Research 74, 623-631.

Holt R.D. (1996) Food webs in space: an island biogeographic perspective. In: Food webs integration of patterns and dynamics (eds Polis GA \& Winemiller KO), pp. 313-323. Chapman \& Hall, New York. 
Holt R.D. (2002) Food webs in space: On the interplay of dynamic instability and spatial processes. Ecological Research 17, 261-273.

Holt R.D. \& Barfield M. (2003) Impacts of temporal variation on apparent competition and coexistence in open ecosystems. Oikos 101, 49-58.

Holt R.D. \& Hochberg M.E. (2001) Indirect interactions, community modules and biological control: a theoretical perspective. In: Evaluating indirect ecological effects of biological control (eds Wajnberg E., Scott J.K. \& Quimby P.C.), pp. 13-37. CABI Publishing, Wallingford UK.

Holt R.D., Lawton J.H., Polis G.A. \& Martinez N.D. (1999) Trophic rank and the species-area relationship. Ecology 80, 1495-1504.

Horstmann K. (1981) Revision der Europäischen Tersilochinen II (Hymenoptera: Ichneumonidae). Spixiana Suppl. 4, 1-76.

Humphreys I.C. \& Mowat D.J. (1994) Effects of some organic treatments on predators (Coleoptera: Carabidae) of cabbage root fly, Delia radicum (L.) (Diptera: Anthomyiidae), and on alternative prey species. Pedobiologia 38, 513-518.

Hyvonen T. \& Salonen J. (2002) Weed species diversity and community composition in cropping practices at two intensity levels - a six-year experiment. Plant Ecology 159, 73-81.

Janetos A.C. (1982) Foraging tactics of two guilds of web-spinning spiders. Behavioural Ecology and Sociobiology 10, 19-27.

Kareiva P. (1990) Population dynaics in spatially complex environments: theory and data. Philosophical Transactions of the Royal Society of London, Series B: Biological Sciences 330, 175-190.

Kareiva P. (1990) The spatial dimension in pest-enemy interactions. In: Critical issues in biological control (eds Machauer M., Ehler L.E. \& Roland J.), pp. 213-226. Intercept press, Andover UK.

Kareiva P. \& Wennegren U. (1995) Connecting landscape patterns to ecosystem and population processes. Nature 373, 299-302.

Kean J., Wratten S., Tylianakis J. \& Barlow N. (2003) The population consequences of natural enemy enhancement, and implications for conservation biological control. Ecology Letters 6, 604-612.

Kleijn D. \& Sutherland W.J. (2004) How effective are European agri-environment schemes in conserving and promoting biodiversity? Journal of Applied Ecology 40, 947-969.

Krauss J., Steffan-Dewenter I. \& Tscharntke T. (2003) How does the landscape context contribute to effects of habitat fragmentationon diversity and population density of butterflies? Journal of Biogeography 30, 889-900.

Krebs J.R., Wilson J.D., Bradbury R.B. \& Siriwardena G.M. (1999) The second silent spring? Nature 400, 611-612.

Kruess A. \& Tscharntke T. (2000) Effects of habitat fragmentation on plant-insect communities. In: Interchanges of insects between agricultural and surrounding landscapes (eds Ekbom B, Irwin ME \& Robert Y), pp. 53-70. Kluwer Academic Publishers, Dordrecht.

Kruess A. \& Tscharntke T. (1994) Habitat fragmentation, species loss, and biological control. Science 264, 1581-1584.

Landis D.A., Wratten S.D. \& Gurr G.M. (2000) Habitat management to conserve natural enemies of arthropod pests in agriculture. Annual Review of Entomology 45, 175-201.

Lang A. (2003) Intraguild interference and biocontrol effects of generalist predators in a winter wheat field. Oecologia 134, 144-153. 
Lee J.C., Menalled F.B. \& Landis D.A. (2001) Refuge habitats modify impact of insecticide disturbance on carabid beetle communities. Journal of Applied Ecology 38, 472-483.

Legendre P. \& Legendre L. (1998) Numerical Ecology. Elsevier, Amsterdam.

Lemke A. \& Poehling H.-M. (2002) Sown weed strips in cereal fields: overwintering site and "source" habitat for Oedothorax apicatus (Blackwall) and Erigone atra (Blackwall) (Araneae: Erigonidae). Agriculture, Ecosystems and Environment 90, 67-80.

Levie A., Dogot P. \& Hance T. (2000) Release of Aphidius rhopalosiphi (Hymenopter: Aphidiinae) for cereal aphid control: field cage experiments. European Journal of Entomology 97, 527-531.

Longley M. \& Jepson P.C. (1996) Effects of honeydew and insecticide residues on the distribution of foraging aphid parasitoids under glasshouse and field conditions. Entomologia Experimentalis et Applicata 81, 189-198.

Loreau M. (2000) Are communities saturated? On the relationship between $\alpha, \beta$ and $\gamma$ diversity. Ecology Letters 3, 73-76.

Losey J.E. \& Denno R.F. (1999) Factors facilitating synergistic predation: the central role of synchrony. Ecological Applications 9, 378-386.

Losey J.E. \& Denno R.F. (1998) Positive predator-predator interactions: enhanced predation rates and synergistic suppression of aphid populations. Ecology 79, 2143-2152.

Łuczak J. (1979) Spiders in agrocenoses. Polish ecological studies 5, 151-200.

Marc P., Canard A. \& Ysnel F. (1999) Spiders (Araneae) useful for pest limitation and bioindication. Agriculture, Ecosystems and Environment 74, 229-273.

Marshall E.J.P. \& Moonen A.C. (2002) Field margins in northern Europe: their functions and interactions with agriculture. Agriculture, Ecosystems and Environment 89, 5-21.

Menalled F.D., Gross K.L. \& Hammond M. (2001) Weed aboveground and seedbank community responses to agricultural management systems. Ecological Applications 11, 1586-1601.

Menalled F.D., Marino P.C., Gage S.H. \& Landis D.A. (1999) Does agricultural landscape structure affect parasitism and parasitoid diversity? Ecological Applications 9, 634-641.

Moran M.D. (2003) Arguments for rejecting the sequential Bonferroni in ecological studies. Oikos 100, 403-405.

Moreby S.J., Aebischer N.J., Southway S.E. \& Sotherton N.W. (1994) A comparison of the flora and arthropod fauna of organically and conventionally grown winter wheat in southern England. Annals of Applied Biology 125, 13-27.

Müller C.B. \& Godfray H.C.J. (1999) Predators adn mutualists influence the exclusion of aphid species from natural communities. Oecologia 119, 120-125.

Niedersächsisches Landesamt für Statistik (2001) Agrarstrukturerhebung 2001.

Nyffeler M. (1999) Prey selection of spiders in the field. Journal of Arachnology 27, 317-324.

Nyffeler M. \& Benz G. (1988) Prey and predatory importance of micryphantid spiders in winter wheat fields and hay meadows. Journal of Applied Entomology 105, 190-197.

Nyffeler M. \& Sunderland K.D. (2003) Composition, abundance and pest control potential of spider communities in agroecosystems: a comparison of European and US studies. Agriculture, Ecosystems and Environment 95, 579-612.

Östman Ö., Ekbom B. \& Bengtsson J. (2001) Farming practice and landscape heterogeneity influence biological control. Basic and Applied Ecology 2, 365-371. 
Östman Ö., Ekbom B. \& Bengtsson J. (2003) Yield increase attributable to aphid predation by ground-living polyphagous natural enemies in spring barley in Sweden. Ecological Economics 45, 149-158.

Pfiffner L. \& Luka H. (2003) Effects of low-input farming systems on carabids and epigeal spiders - a paired farm approach. Basic and Applied Ecology 4, 117-127.

Pfiffner L. \& Niggli U. (1996) Effects of bio-dynamic, organic and conventional farming on ground beetles (Col. Carabidae) and other epigaeic arthropods in winter wheat. Biological Agriculture and Horticulture 12, 353-364.

Raymond B., Darby A.C. \& Douglas A.E. (2000) Intraguild predators and the spatial distribution of a parasitoid. Oecologia 124, 367-372.

Ricklefs R.E. (1987) Community diversity: relative roles of local and regional processes. Science 235, 167-171.

Riechert S.E. \& Bishop L. (1990) Prey control by an assemblage of generalist predators: spiders in garden test systems. Ecology 71, 1441-1450.

Riechert S.E. \& Lockley T. (1984) Spiders as biological control agents. Annual Review of Entomology 29, 199-320.

Ritchie M.E. \& Olff H. (1999) Spatial scaling laws yield a synthetic theory of biodiversity. Nature 400, 557-560.

Roberts M.J. (1995) Spiders of Britain and Northern Europe. Harper Collins, London.

Roland J. \& Taylor P.D. (1997) Insect parastioid species respond to forest structure at different spatial scales. Nature 386, 710-713.

Rosenheim J.A. (1998) Higher-order predators and the regulation of insect herbivore populations. Annual Review of Entomology 43, 421-447.

Rosenheim J.A., Kaya H.K., Ehler L.E., Marois J.J. \& Jaffee B.A. (1995) Intraguild predation among biological-control agents: theory and evidence. Biological Control 5, 303-335.

Rypstra A.L., Carter P.E., Balfour R.A. \& Marshall S.D. (1999) Architectural features of agricultural habitats and their impact on the spider inhabitants. Journal of Arachnology 27, 371-377.

Samu F., Sunderland K.D. \& Szinetár C. (1999) Scale-dependent dispersal and distribution patterns of spiders in agricultural systems: a review. Journal of Arachnology 27, 325-332.

Samu F. \& Szinetár C. (2002) On the nature of agrobiont spiders. Journal of Arachnology 30, 389-402.

Scheu S. (2001) Plants and generalist predators as links between the below-ground and aboveground system. Basic and Applied Ecology 2, 3-13.

Schmidt M.H., Lauer A., Purtauf T., Thies C., Schaefer M. \& Tscharntke T. (2003) Relative importance of predators and parasitoids for cereal aphid control. Proceedings of the Royal Society of London Series B-Biological Sciences 270, 1905-1909.

Schmitz O.J., Hambäck P.A. \& Beckermann A.P. (2000) Trophic cascades in terrestrial ecosystems: a review of the effects of carnivore removal on plants. The American Naturalist $155,141-153$.

Settle W.H., Ariawan H., Astuti E.T., Cahyana W., Hakim A.L., Hindayana D. \& Lestari A.S. (1996) Managing tropical rice pests through conservation of generalist natural enemies and alternative prey. Ecology 77, 1975-1988.

Sigsgaard L. (2002) A survey of aphids and aphid parasitoids in cereal fields in Denmark, and the parasitoids' role in biological control. Journal of Applied Entomology 126, 101-107. 
Sih A., Englund G. \& Wooster D. (1998) Emergent impacts of multiple predators on prey. Trends in Ecology and Evolution 13, 350-355.

Snyder W.E. \& Ives A.R. (2001) Generalist predators disrupt biological control by a specialist parasitoid. Ecology 82, 705-716.

Snyder W.E. \& Ives A.R. (2003) Interctions between specialist and generalist natural enemies: parasitoids, predators, and pea aphid biocontrol. Ecology 84, 91-107.

Snyder W.E. \& Wise D.H. (2001) Contrasting trophic cascades generated by a community of generalist predators. Ecology 82, 1571-1583.

Srivastava D.S. (1999) Using local-regional richness plots to test for species saturation: pitfalls and potentials. Journal of Animal Ecology 68, 1-16.

Staddon P.L. (2004) Carbon isotopes in functional soil ecology. Trends in Ecology and Evolution 19, 148-154.

StatSoft I. (2000) STATISTICA for Windows. Tulsa, OK.

Steffan-Dewenter I. (2002) Landscape context affects trap-nesting bees, wasps, and their natural enemies. Ecological Entomology 27, 631-637.

Steffan-Dewenter I., Münzenberg U., Burger C., Thies C. \& Tscharntke T. (2002) Scaledependent effects of landscape context on three pollinator guilds. Ecology 83, 1421-1432.

Steffan-Dewenter I., Münzenberg U. \& Tscharntke T. (2001) Pollination, seed set and seed predation on a landscape scale. Proceedings of the Royal Society of London, Series B: Biological Sciences 268, 1685-1690.

Stewart A.J.A. \& Wright A.F. (1995) A new inexpensive suction apparatus for sampling arthropods in grassland. Ecological Entomology 2, 98-102.

Stoate C., Boatman N.D., Borralho R.J., Carvalho C.R., de Snoo G.R. \& Eden P. (2001) Ecological impacts of arable intensification in Europe. Journal of Environmental Management 63, 337-365.

Sunderland K. \& Samu F. (2000) Effects of agricultural diversification on the abundance, distribution, and pest control potential of spiders: a review. Entomologia Experimentalis et Applicata 95, 1-13.

Sunderland K.D., Axelsen J.A., Dromph K., Freier B., Hemptinne J.-L., Holst N.H., Mols P.J.M., Petersen M.K., Powell W., Ruggle P., Trilsch H. \& Winder L. (1997) Pest control in a community of natural enemies. Acta Jutlandica 72, 271-326.

Suter R.B. (1999) An aerial lottery: the physics of ballooning in a chaotic atmosphere. Journal of Arachnology 27, 281-293.

Symondson W.O.C., Sunderland K.D. \& Greenstone H.M. (2002) Can generalist predators be effective biocontrol agents? Annual Review of Entomology 47, 561-594.

Thies C., Steffan-Dewenter I. \& Tscharntke T. (2003) Effects of landscape context on herbivory and parasitism at different spatial scales. Oikos 101, 18-25.

Thies C., Steffan-Dewenter I. \& Tscharntke T. (in review) Plant pest-natural enemy interactions in spatio-temporally changing agricultural landscapes.

Thies C. \& Tscharntke T. (1999) Landscape structure and biological control in agroecosystems. Science 285, 893-895.

Thomas C.F.G., Brain P. \& Jepson P.C. (2003) Aerial activity of linyphiid spiders: modelling dispersal distances from meteorology and behaviour. Journal of Applied Ecology 40, $912-$ 927. 
Thomas C.F.G., Hol E.H.A. \& Everts J.W. (1990) Modelling the diffusion component of dispersal during recovery of a population of linyphiid spiders from exposure to an insecticide. Functional Ecology 4, 357-368.

Thomas C.F.G. \& Jepson P.C. (1999) Differential aerial dispersal of linyphiid spiders from a grass and a cereal field. Journal of Arachnology 27, 294-300.

Thomas C.F.G. \& Jepson P.C. (1997) Field-scale effects of farming practices on linyphiid spider populations in grass and cereals. Entomologia Experimentalis et Applicata 84, 59-69.

Thorbek P., Sunderland K.D. \& Topping C.J. (2003) Eggsac development rates and phenology of agrobiont linyphiid spiders in relation to temperature. Entomologica Experimentalis et Applicata 109, 89-100.

Thorbek P., Topping C.J. \& Sunderland K.D. (2002) Validation of a simple method for monitoring aerial activity of spiders. Journal of Arachnology 30, 57-64.

Tilman D., Cassman K.G., Matson P.A., Naylor R. \& Polasky S. (2002) Agricultural sustainability and intensive production practices. Nature 418, 671-677.

Toft S. (1995) Two functions of gossamer dispersal in spiders? Acta Jutlandica 70, 257-268.

Toft S., Vangsgaard C. \& Goldschmidt H. (1995) Distance methods used to estimate densities of web spiders in cereal fields. Acta Jutlandica 70, 33-45.

Topping C.J. (1999) An individual-based model for dispersive spiders in agroecosystems: simulations of the effects of landscape stucture. Journal of Arachnology 27, 378-386.

Topping C.J. (1997) Predicting the effect of landscape heterogeneity on the distribution of spiders in agroecosystems using a population dynamics driven landscape-scale simulation model. Biological Agriculture and Horticulture 15, 325-336.

Topping C.J. \& Sunderland K.D. (1992) Limitations in the use of pitfall traps in ecological studies exemplified by a study of spiders in a field of winter wheat. Journal of Applied Ecology 29, 485-491.

Topping C.J. \& Sunderland K.D. (1994) A spatial population dynamics model for Lepthyphantes tenuis (Araneae: Linyphiidae) with some simulations of the spatial and temporal effects of farming operations and land-use. Agriculture, Ecosystems and Environment 48, 203-217.

Tscharntke T. (2000) Parasitoid populations in the agricultural landscape. In: Parasitoid population biology (eds Hochberg M.E. \& Ives A.R.), pp. 235-253. Princeton University Press, Princeton.

Tscharntke T. \& Brandl R. (2004) Plant-insect interactions in fragmented landscapes. Annual Review of Entomology 49, 405-430.

Tscharntke T., Klein A.-M., Kruess A., Steffan-Dewenter I. \& Thies C. (2003) Biodiversität und Pflanze-Insekt-Interaktionen in Kulturlanschaften. In: Biodiversitätsforschung. Die Entschlüsselung von Artenvielfalt in Raum und Zeit (eds Grandstein S.R., Willmann R. \& Zizka G.), pp. 171-183. E. Schweizbart'sche Verlagsbuchhandlung, Stuttgart.

Tscharntke T., Steffan-Dewenter I., Kruess A. \& Thies C. (2002) Characteristics of insect populations on habitat fragments: a mini review. Ecological Research 17, 229-239.

van Nouhuys S. \& Hanski I. (2002) Multitrophic interactions in space: metacommunity dynamics in fragmented landscapes. In: Multitrophic level interactions (eds Tscharntke T. \& Hawkins B.A.), pp. 127-147. Cambridge University Press, Cambridge.

van Schelt J. \& Mulder S. (2000) Improved methods of testing an release of Aphidoletes aphidimyza (Diptera: Cecidomyiidae) for aphid control in glasshouses. European Journal of Entomology 97, 511-515. 
Vickerman G.P. \& Sunderland K.D. (1975) Arthropods in cereal crops: nocturnal activity, vertical distribution and aphid predation. Journal of Applied Ecology 12, 755-766.

Völkl W. (1992) Aphids or their parasitoids: who actually benefits from ant-attendance? Journal of Animal Ecology 61, 273-281.

Vugts H.F. \& van Wingerenden W.K.R.E. (1976) Meteorological aspects of aeronautic behaviour of spiders. Oikos 27, 433-444.

Weibull A.C. \& Östman O. (2003) Species composition in agroecosystems: the effect of landscape, habitat, and farm management. Basic and Applied Ecology 4, 349-361.

Westphal C., Steffan-Dewenter I. \& Tscharntke T. (2003) Mass flowering crops enhance pollinator densities at a landscape scale. Ecology Letters 6, 961-965.

Weyman G.S., Jepson P.C. \& Sunderland K.D. (1995) Do seasonal changes in numbers of aerially dispersing spiders reflect population-density on the ground or variation in ballooning motivation? Oecologia 101, 487-493.

Weyman G.S., Sunderland K.D. \& Fenlon J.S. (1994) The effect of food depriviation on aeronautic dispersal behaviour (ballooning) in Erigone spp. spiders. Entomologia Experimentalis et Applicata 73, 121-126.

Winder L. (1990) Predation of the cereal aphid Sitobion avenae by polyphagous predators on the ground. Ecological Entomology 15, 105-110.

Winder L., Hirst D.J., Carter N., Wratten S.D. \& Sopp P.I. (1994) Estimating predation of the grain aphid Sitobion avenae by polyphagous predators. Journal of Applied Ecology 31, 112.

Wise D.H. (1993) Spiders in ecological webs. Cambridge University Press, Cambridge.

Wise D.H., Snyder W.E., Tuntibunpakul P. \& Halaj J. (1999) Spiders in decomposition food webs of agroecosystems: theory and evidence. Journal of Arachnology 27, 363-370.

Wissinger S. (1997) Cyclic colonization in predictably ephemeral habitats: a template for biological control in annual crop systems. Biological Control 10, 4-15.

With K.A. \& Christ T.O. (1995) Critical thresholds in species' response to landscape structure. Ecology 76, 2446-2459.

With K.A., Pavuk D.M., Worchuck J.L., Oates R.K. \& Fisher J.L. (2002) Threshold effects of landscape structure on biological control in agroecosystems. Ecological Applications 12, $52-65$.

Wratten S.D. \& Powell W. (1991) Cereal aphids and their natural enemies. In: The ecology of temperate cereal fields (eds Firbank I.G., Carter N., Darbyshire J.F. \& Potts G.R.), pp. 233257. Blackwell Science, Oxford.

Wratten S.D. \& van Emden H.F. (1995) Habitat management for enhanced activity of natural enemies on insect pests. In: Ecology and integrated farming systems. 32nd symposium of the British Ecological Society (eds Glen D.M., Greaves M.P. \& Anderson H.M.), pp. 117145. John Wiley \& Sons, UK.

Zobel M. (1997) The relative role of species pools in determining plant species richness: an alternative explanantion of species coexistence? Trends in Ecology and Evolution 12, 266269. 


\section{Summary}

Agriculture is substantially influencing the habitats of wild animal and plant species, but also benefits from services provided by these species, for example from the natural control of crop pests. Annual crops are predominately inhabited by mobile species that spend part of their life cycle in other habitats. Therefore, animal communities in annual crops should be affected by the composition of the surrounding landscape. This study investigates landscape effects on farmland spiders and compares them to the effects of local management. In addition, the relative importance of spiders and other natural enemies for cereal aphid control is analyzed using field experiments.

The study took place in 76 wheat fields and 24 other habitats (fallow, grassland, springsown crops) around the city of Göttingen, Germany. The majority of spider species typical for annual crops were several times more abundant in grasslands and fallows during spring. Species richness of ground-dwelling spiders was enhanced from on average 12 to 20 species per wheat field by the percentage of non-crop habitats (13$69 \%$ ) in the surrounding landscape. Organic management did not affect species richness, but increased activity density by $62 \%$ compared to conventionally managed fields. Abundances of sheetweb spiders were enhanced by high percentages of non-crop habitats in 1 to $3 \mathrm{~km}$ circumference, e.g. from on average 18 to 130 webs per $\mathrm{m}^{2}$ in late May 2001. The positive effect of non-crop habitats on sheetweb weavers appeared to depend on suitable weather for their aerial dispersal (ballooning). In field experiments, ground-dwelling predators (mostly spiders), parasitoid wasps and aphid-eating larvae of Diptera each reduced aphid infestations by $31-51 \%$, complementing each other. Mulch enhanced spider densities and thereby reduced aphid populations by $25 \%$.

Consequently, spiders contribute to the natural control of cereal aphids and can be enhanced by practices such as organic farming and mulch. Spider populations in cereal fields further depend on the composition of the surrounding landscapes. Habitats such as grasslands and fallows should be preserved to allow for abundant, species-rich spider communities in crop fields. Overall, it appears that many natural enemies of arable crop pests benefit from the availability of non-crop habitats in the landscape. Considering large spatial and temporal scales appears to be essential to improve our understanding of population dynamics of farmland arthropods, and to develop biological control strategies. 


\section{Zusammenfassung}

Die Landwirtschaft formt einerseits maßgeblich den Lebensraum freilebender Tier- und Pflanzenarten und profitiert andererseits von den Leistungen dieser Arten, beispielsweise von der natürlichen Schädlingskontrolle. Einjährige Kulturen werden überwiegend von mobilen Arten bewohnt, die einen Teil ihres Lebenszyklus' außerhalb der Felder in anderen Lebensräumen verbringen. Deshalb sollte das Vorkommen dieser Arten von der Zusammensetzung der Landschaft abhängen. In dieser Arbeit werden Landschaftseffekte auf Spinnen in Getreidefeldern untersucht und mit der Wirkung der lokalen Bewirtschaftungsweise verglichen. Ferner wird der Beitrag von Spinnen und anderen Gegenspielern zur natürlichen Kontrolle von Getreideblattläusen, einem der Hauptschädlinge im Getreide, anhand von Freilandexperimenten getestet.

Die Untersuchungen fanden in insgesamt 76 Weizenfeldern und 24 anderen Lebensräumen (Brachen, Grünland, Sommerkulturen) in der Umgebung von Göttingen statt. Sie ergaben, dass die meisten für Äcker typischen Spinnenarten im Frühjahr in Grünländern und Brachen in mehrfach höheren Dichten vorkamen als auf den Feldern. Der Artenreichtum bodenlebender Spinnen stieg mit dem Anteil an Nicht-Ackerflächen (13-69\%) in der umgebenden Landschaft von durchschnittlich 12 auf 20 Arten pro Weizenfeld. Ökologische Bewirtschaftung wirkte sich nicht auf den Artenreichtum aus, steigerte jedoch die Aktivitätsdichten bodenlebender Spinnen um 62\% gegenüber konventionellen Feldern. Die Dichten von Baldachinspinnen in Weizenfeldern wurden durch hohe Anteile naturnaher Lebensräume in 1 bis $3 \mathrm{~km}$ Umgebung deutlich erhöht, beispielsweise von 18 auf 130 Netze pro $\mathrm{m}^{2}$ Ende Mai 2001. Der positive Einfluss der Landschaft auf die Dichten von Baldachinspinnen schien von geeignetem Wetter für die Ausbreitung durch die Luft abzuhängen. In Freilandexperimenten haben bodenlebende Räuber (v.a. Spinnen), Schlupfwespen und blattlausfressende Dipterenlarven den Befall mit Getreideblattläusen um je 31-51\% verringert und sich dabei ergänzt. Mulch erhöhte die Spinnendichte und verringerte dadurch den Blattlausbefall um 25\%.

Folglich sind Spinnen an der natürlichen Kontrolle von Getreideblattläusen beteiligt und lassen sich durch Maßnahmen wie ökologische Bewirtschaftung und Mulch fördern. Darüber hinaus hängt das Vorkommen von Spinnen auf Äckern in hohem Maße von der Zusammensetzung der umgebenden Landschaft ab. Naturnahe Lebensräume wie 
Grünländer und Brachen sollten erhalten werden, um arten- und individuenreiche Spinnengemeinschaften auch auf Äckern zu ermöglichen. Zahlreiche Gegenspieler schädlicher Insekten im Ackerbau profitieren vom Angebot naturnaher Lebensräume auf Landschaftsebene. Die Betrachtung großer räumlicher und zeitlicher Skalen ist für das Verständnis der Populationsdynamik von Arthropoden im Kulturland unverzichtbar. Aufgrund ihrer großen Bedeutung sollte die Landschaft bei der Entwicklung biologischer Schädlingskontrolle berücksichtigt werden. 


\section{Danksagung}

Mein besonderer Dank gilt Prof. Dr. Teja Tscharntke für die Überlassung des Themas und die hervorragende Betreuung und Unterstützung von der Planung der Freilandarbeit bis zur Publikation. Prof. Dr. Matthias Schaefer hat durch seine Lehre den Arachnologen in mir geweckt, die Doktorarbeit mitbetreut und dadurch sehr zu ihrem Gelingen beigetragen. Prof. Dr. Stefan Vidal danke ich für die freundliche Übernahme des Korreferats und für die gute Zusammenarbeit im Rahmen des BIOPLEX-Projektes.

Ganz herzlich bedanken möchte ich mich auch bei Dr. Carsten Thies für die immer freundliche, sehr effektive Zusammenarbeit. Indra Roschewitz war so nett, mich in ihre Untersuchung ökologisch und konventionell bewirtschafteter Weizenfelder im Landschaftsgradienten einzubeziehen. Andreas Lauer und Ulrich Thewes haben in ihren Diplomarbeiten zu den Interaktionen kleiner Tiere Großes geleistet. Beim gesamten Göttinger Fachgebiet Agrarökologie bedanke ich mich für die tolle Arbeitsatmosphäre, die anregenden Diskussionen und die große Hilfsbereitschaft. Der Studienstiftung des deutschen Volkes bin ich für finanzielle und ideelle Unterstützung dankbar.

Für wertvolle Kommentare zu den Manuskripten danke ich Prof. Dr. James Cronin, Prof. Dr. Geoff Gurr, Prof. Dr. Robert Holt, Prof. Dr. Douglas Landis, Prof. Dr. Nick Mills, Dr. Örjan Östman, Prof. Dr. Jay Rosenheim, Prof. Dr. Stefan Scheu, Dr. Keith Sunderland, Dr. George Thomas, Prof. Dr. Søren Toft, Jason Tylianakis, Prof. Dr. David Wise und zahlreichen anonymen Gutachtern. Theo Blick und Dr. Oliver-David Finch haben Spinnen nachbestimmt, und Christian Kluth half mir bei der Statistik für Kapitel 3.

Dr. Thorsten Behrens, Dr. Jens Dauber, Julia Morzfeld, Tobias Purtauf, Lars Reimer, Prof. Dr. Volkmar Wolters und Olaf Zeigan danke ich für die nette, konstruktive Zusammenarbeit im Rahmen von BIOPLEX. Darüber hinaus waren Christof Bürger, Doreen Gabriel, Anne le Mellec und Catrin Westphal an der Kartierung und Verarbeitung der Landschaftsdaten beteiligt.

Nicht zuletzt möchte ich meiner Freundin Wiebke Entling, meiner Familie und allen Freunden danken, die für Ablenkung und Ausgleich gesorgt haben und ganz großartig sind!

All diesen Personen vielen herzlichen Dank! 


\section{Publikationen}

Schmidt M.H., Lefebvre G., Poulin B. \& Tscharntke T. (2004) Reed cutting affects arthropod communities, potentially reducing food to passerine birds. Biological Conservation, in press.

Schmidt M.H., Thies C. \& Tscharntke T. (2004) The landscape context of arthropod biological control. Ecological Engineering for Pest Management: Advances in Habitat Manipulation for Arthropods (eds. GM Gurr, SD Wratten \& MA Altieri), CSIRO Press, in press.

Schmidt M.H. \& Tscharntke T. (2004) The role of perennial habitats for Central European farmland spiders. Agriculture, Ecosystems and Environment, in press.

Schmidt M.H., Lauer A., Purtauf T., Thies C., Schaefer M. \& Tscharntke T. (2003) Relative importance of predators and parasitoids for cereal aphid control. Proceedings of the Royal Society of London, Series B: Biological Sciences 270, 1905-1909.

Schmidt M.H., Thies C. \& Tscharntke T. (2003) Landscape complexity determines spider densities in cereal fields. Verhandlungen der Gesellschaft für Ökologie 33, 60.

Schmidt M., Lauer A., Purtauf T., Thies C., Schaefer M. \& Tscharntke T. (2002) Top-down control of cereal aphids by their natural enemies. Verhandlungen der Gesellschaft für Ökologie 32, 359.

Schmidt M., Lefebvre G., Poulin B. \& Tscharntke T. (2001) Arthropoden, Singvögel und ihre Interaktionen in gemähten und ungemähten Schilfgebieten. Mitteilungen der Deutschen Gesellschaft für Allgemeine und Angewandte Entomologie 13, 41-44.

Schmidt M.H., Thewes U., Thies C. \& Tscharntke T. (eingereicht) Aphid suppression by natural enemies in mulched cereals.

Schmidt M.H., Roschewitz I., Thies C. \& Tscharntke T. (eingereicht) Landscape context affects the diversity, and local management the density of ground-dwelling farmland spiders.

Schmidt M.H., Clough Y., Schulz W., Westphalen A. \& Tscharntke T. (eingereicht) Arthropod capture efficiency and preservation attributes of fluids in pitfall traps.

Schmidt M.H. \& Tscharntke T. (eingereicht) Landscape context of sheetweb spider population dynamics in cereal fields. 


\section{Lebenslauf}

Martin H. Schmidt

geboren am 11.05.1974 in Erlangen

2000-2004 Promotion am Fachgebiet Agrarökologie der Georg-AugustUniversität Göttingen bei Prof. Dr. Teja Tscharntke, gefördert von der Studienstiftung des deutschen Volkes

2000

Abschluss der Diplomprüfung im Studiengang Biologie ,mit Auszeichnung'

1999-2000 Diplomarbeit „Die Auswirkungen der Mahd auf Arthropoden und Singvögel in Schilfbeständen“. Betreuer: Prof. Dr. M. Schaefer (Göttingen), Anleiter: Prof. Dr. T. Tscharntke (Göttingen), Zusammenarbeit mit Dr. B. Poulin (Siebenmonatiger Aufenthalt an der Station Biologique de la Tour du Valat in Frankreich)

1994-2000 Studium der Biologie an der Georg-August-Universität Göttingen, Fächerkombination Zoologie, Botanik \& Naturschutz

1993-1994 Zivildienst in Keitum/Sylt bei der Naturschutzgesellschaft Schutzstation Wattenmeer e.V., Sitz Rendsburg 